\title{
Secretory Autoantibodies in Rheumatoid Arthritis
}

\section{Karin Roos Ljungberg}
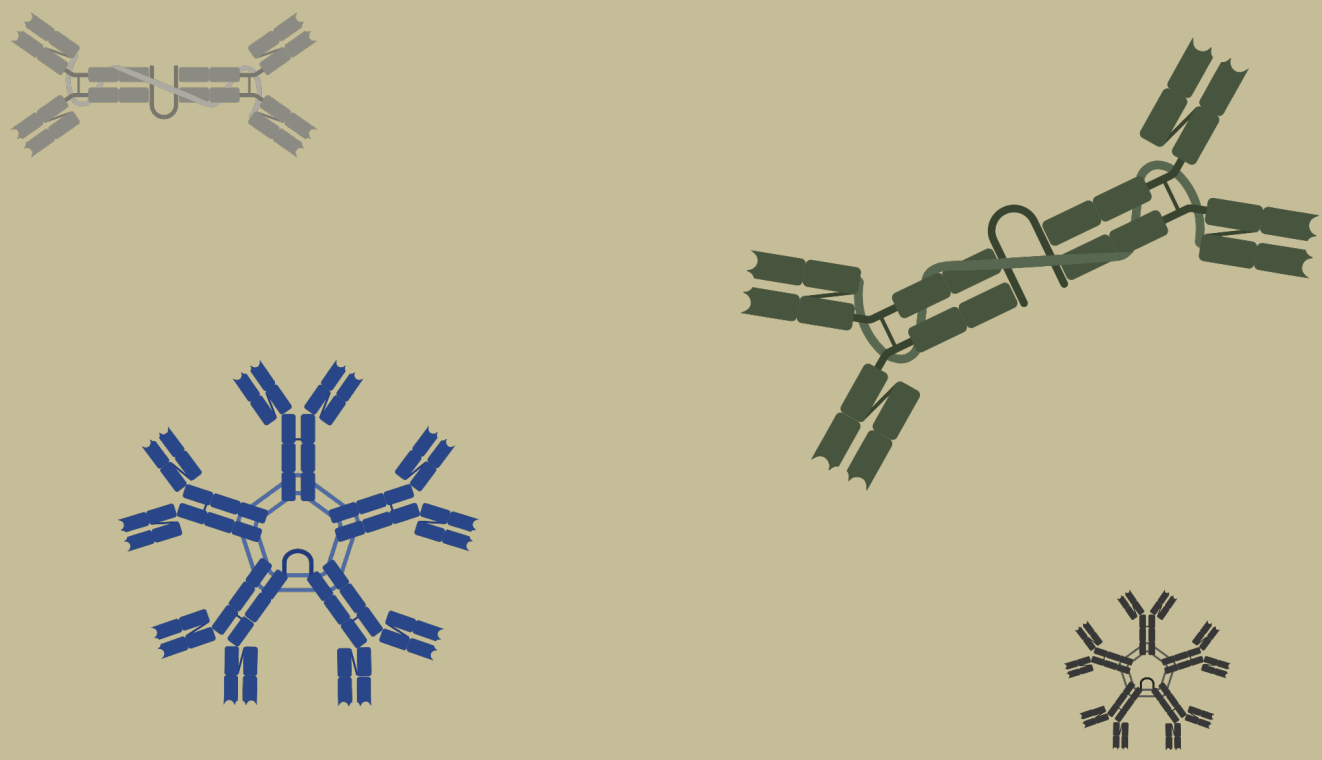



\title{
Secretory Autoantibodies in Rheumatoid Arthritis
}

\author{
Karin Roos Ljungberg
}

Department of Biomedical and Clinical Sciences

Division of Inflammation and Infection

Faculty of Medicine and Health Sciences

Linköpings universitet, SE-581 83 Linköping, Sweden Linköping 2022 
(C) Karin Roos Ljungberg, 2022

(c) (i) (8) This work is licensed under the Creative Commons Attribution-NonCommercial 4.o International License.

http://creativecommons.org/licenses/by-nc/4.0/

Published papers have been reprinted with the permission of the copyright holder. Illustrations in the thesis and the front cover are created with BioRender.com.

Printed in Sweden by LiU-Tryck, 2022

ISBN 978-91-7929-176-1 (print)

ISBN 978-91-7929-177-8 (PDF)

https://doi.org/10.3384/9789179291778

ISSN $0345-0082$ 
To Daniel, Axel and Anders 



\section{Table of content}

Abstract.....................................................................................................

Populärvetenskaplig sammanfattning.........................................................9

Abbreviations …....................................................................................11

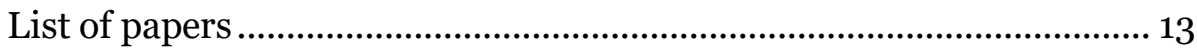

Introduction ............................................................................................... 15

Rheumatoid arthritis .......................................................................... 15

Clinical features and classification.............................................15

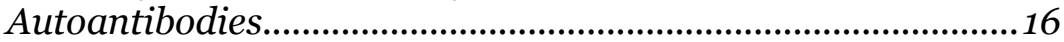

Etiopathogenesis .......................................................................2O

Preclinical period ..........................................................................21

The mucosal immune system....................................................................23

The mucosal origin hypothesis in $R A$..........................................25

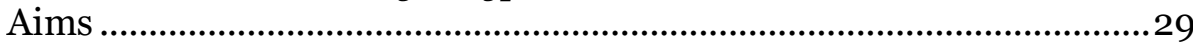

Material and methods.............................................................................. 31

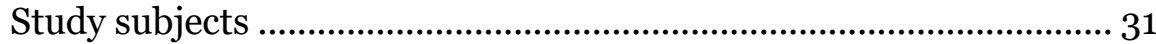

Timely interventions in $R A$ (TIRA)-1 and -2 studies................. 31

Lung investigation in newly diagnosed RA (LURA) study ......32

Secretory ACPA in RA (SARA) study ...........................................33

Extra-early rheumatology follow-up (TIRx) study ...................33

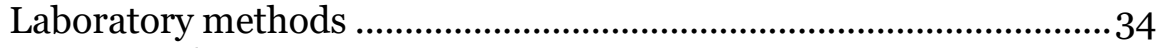

Sampling …………...................................................................... 34

Antibody analyses.........................................................................34

Western blot analysis.................................................................... 38

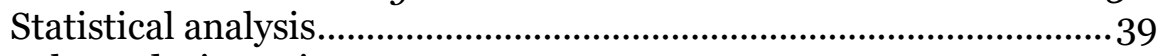

Results and Discussion ............................................................................ 41

Occurrence of secretory ACPA ............................................................. 41

Circulation ……............................................................................. 41

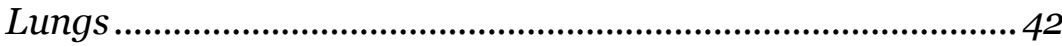

Oral cavity ..................................................................................43

Circulating versus mucosal secretory ACPA .............................. 44

Secretory ACPA versus risk factors for RA..............................................46

Smoking ......................................................................................46

Genetic predisposition (shared epitope) ....................................4 47

Secretory ACPA versus RA manifestations .........................................48

Secretory ACPA versus disease activity .......................................48

Secretory ACPA and the lungs .....................................................4 49

IgA ACPA and the oral cavity .................................................... 51

Secretory ACPA and radiographic outcomes .............................52

Prognostic value of secretory ACPA ............................................ 52

Mucosal pathogenesis.............................................................................54

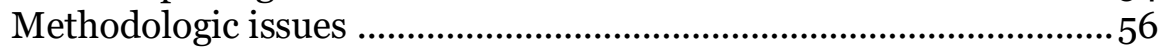




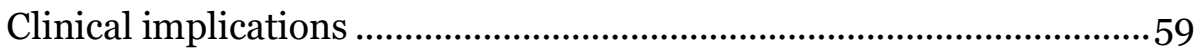

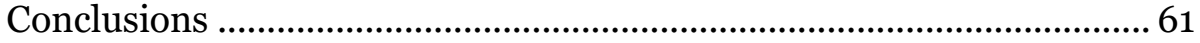

Future perspectives ................................................................................63

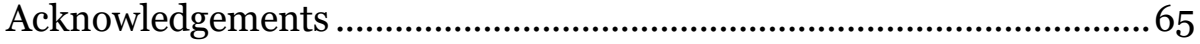

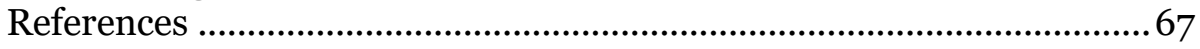




\section{Abstract}

Rheumatoid arthritis (RA) is a chronic autoimmune inflammatory disease in which autoantibodies, such as anti-citrullinated protein antibodies (ACPA), can be detected in the serum of patients. Autoantibodies may appear in the circulation years before clinical signs of joint inflammation occur, indicating that early immunological pathogenetic steps take place outside of the joints. Although many of these mechanisms are currently unknown, the initial events leading up to ACPA production are thought to occur at mucosal surfaces. In this thesis, mucosa-associated secretory ACPA are investigated in the circulation and in local mucosal secretions to: (i) improve the understanding of the mucosal connection in RA; and (ii) investigate whether these antibodies can improve diagnostics and prognostics in early RA.

We identified circulating secretory component containing (SC) ACPA in a subpopulation of patients (both early and established RA) and atrisk patients, with a prevalence of $16 \%$-21\%. In addition, SC ACPA was detected in bronchoalveolar lavage fluid (BALF) and IgA ACPA in saliva, indicating local production in the lungs and in the oral cavity. In at-risk patients who were positive for IgG ACPA, we found that the levels of circulating SC ACPA at inclusion predicted arthritis development. Circulating SC ACPA was associated with higher disease activity, including increased levels of inflammatory markers, in patients with early RA. Levels of circulating SC ACPA were associated with high-resolution computed tomography (HRCT) findings (parenchymal lung abnormalities and bronchiectasis) and smoking, but not with risk genes (shared epitope). We confirmed the presence of salivary ACPA and identified a novel association with increased disease activity and functional disability.

In summary, SC ACPA is present in the sera of patients with RA who manifest different phases of the disease, and we found associations with arthritis onset, smoking, systemic inflammation, and lung abnormalities. SC ACPA is also detectable in mucosal secretions from the lungs and the oral cavity. These findings suggest that mucosal ACPA production may be an important factor in RA development and progression, and that serum SC ACPA should be further evaluated as a prognostic marker for disease onset among at-risk individuals.

Keywords: rheumatoid arthritis, secretory autoantibodies, immunoglobulins, anti-citrullinated protein antibodies, ACPA, mucosal immunity. 


\section{Populärvetenskaplig sammanfattning}

Ledgångsreumatism eller reumatoid artrit (RA) är en inflammatorisk ledsjukdom som 0.5-1\% av befolkningen är drabbad av. Främst småleder, typiskt i händer och fötter, drabbas av inflammation och utan behandling kan sjukdomen orsaka mycket skada för patienten både i form av deformerade leder, ökad sjukdomsbörda i andra sjukdomar (exempelvis hjärtkärlsjukdom) samt sänkt livskvalité. RA har både riskfaktorer kopplade till miljön samt har kända ärftliga riskfaktorer. Den riskfaktorn som finns i miljön som är mest dokumenterad är rökning. Antikroppar kopplade till RA finns rapporterade flera år innan sjukdomen orsakar ledinflammationer vilket är ett tecken på att sjukdomen inte startar vid lederna primärt. Slemhinnor har tilldragit sig ökat intresse då dessa tros vara delaktiga vid tidiga immunologiska mekanismer som leder till utveckling av RA. Då rökning är en väletablerad riskfaktor för RA har slemhinnorna i luftvägarna föreslagits vara primär plats för produktion av antikroppar mot modifierade proteiner [så kallade anti-citrullinerade protein antikroppar (ACPA)]. Även munhålan och magtarmkanalens slemhinnor är potentiella startplatser för de tidiga immunologiska processerna. I den här avhandlingen har slemhinneassocierade (sekretoriska) antikroppar av ACPA typ analyserats i blod samt i lokala slemhinnevätskor i form av lungsköljvätska samt saliv för att studera koppling till slemhinnorna. Syftet var att undersöka om sekretoriska ACPA har betydelse för sjukdomsutvecklingen vid RA samt om de kan tillföra något vid diagnostiken av RA och om de kan förutsäga om personer med ökad risk för RA utvecklar ledinflammation (prognostiskt värde).

I avhandlingen har flera patientmaterial undersökts, både nydiagnostiserade RA patienter, RA patienter med sjukdom sedan flera år (etablerad RA) samt patienter med ökad risk att insjukna i RA har inkluderats. Framför allt har blod (serum) analyserats för sekretoriska ACPA men i två av studierna har också lungsköljvätska och saliv analyserats.

Hos 16\%-21\% av patienterna kunde sekretoriska ACPA detekteras i serum och detta var kopplat till en ökad inflammatorisk aktivitet samt högre sjukdomsaktivitet hos patienterna. Sekretoriska ACPA har också påvisats i lungsköljvätska samt saliv vilket indikerar att dessa antikroppar finns lokalt vid slemhinnor då dessa antikroppar bildas av immunceller vid slemhinnor. Skiktröntgen av lungorna hos nydiagnostiserade RA patienter som inte påbörjat anti-reumatisk behandling visade att de med specifika lungförändringar hade högre nivåer av sekretoriska ACPA i blod. Rökning är starkt kopplat till sekretoriska ACPA i flera av de inkluderade delarbeten i denna avhandling där de som rökt eller röker har i större omfattning sekretoriska ACPA samt att rökare har högre nivåer 
av sekretoriska ACPA i blod. Detta indikerar att slemhinnorna i lungorna troligen har betydelse för tidiga immunologiska förändringar vid RA då rökning orsakar lokal irritation och inflammation i luftvägarna. Förekomst av ACPA i saliv var kopplat till högre sjukdomsaktivitet. Hos riskpersoner noterades att sekretoriska ACPA kan förutspå utveckling av ledinflammationer.

Sammanfattningsvis så kan sekretoriska ACPA detekteras i både blod och lokala sekret från slemhinnor både hos RA patienter och riskpersoner, vilket tyder på att slemhinnorna kan ha en roll i sjukdomsutvecklingen av RA. Dessa antikroppar är kopplade till mera aktiv sjukdom i form av att patienterna har högre nivåer av inflammationsprover samt har mer uttalad självskattad funktionsnedsättning. Ytterligare studier behövs för att avgöra om sekretoriska ACPA kan användas för att förutspå vilka riskpersoner som utvecklar RA. 


\section{Abbreviations}

ACPA anti-citrullinated protein antibodies

ACR

American College of Rheumatology

AKA

anti-keratin antibodies

AMPA

anti-modified protein autoantibodies

Anti-CarP

anti-carbamylated protein

Anti-Pg

APF

antibodies against Porphyromonas gingivalis

AU antiperinuclear factor

BALF arbitrary units

CAP

CI bronchoalveolar lavage fluid cyclic arginine peptide confidence interval

CIA collagen-induced arthritis

CCP cyclic citrullinated peptide

CRP C-reactive protein

DAS28 disease activity score 28

DMARD disease modifying anti-rheumatic drug

EIA enzyme immunoassay

ELISA enzyme-linked immunosorbent assay

ESR erythrocyte sedimentation rate

EULAR European League Against Rheumatism

Fc

FDR fragment crystallizable

HAQ health assessment questionnaire

HLA human leukocyte antigen

HR hazard ratio

HRCT high-resolution computed tomography

Ig immunoglobulin

IL interleukin

$\mathrm{J}$ chain joining chain

M cells microfold cells

MALT mucosa-associated lymphoid tissue

NSAID non-steroidal anti-inflammatory drug

OD optical density

OR odds ratio

P. gingivalis Porphyromonas gingivalis

PAD peptidylarginine deiminase

PBS phosphate-buffered saline

PGA patient global assessment

PIgR polymeric immunoglobulin receptor 
$r \quad$ Spearman's rank correlation coefficient

RA rheumatoid arthritis

$\mathrm{RF}$ rheumatoid factor

SC secretory component

SDS-PAGE sodium dodecyl sulfate-polyacrylamide gel electrophoresis

SE shared epitope

SIgA secretory IgA

SIgM secretory IgM

SJC swollen joint count

TBS Tris-buffered saline

TBS-T Tris-buffered saline-Tween

TJC tender joint count 


\section{List of papers}

This thesis is based on the appended original papers, which are referred to in the text according to their Roman numerals:

I. Roos K, Martinsson K, Ziegelasch M, Sommarin Y, Svärd A, Skogh T, Kastbom A. Circulating secretory IgA antibodies against cyclic citrullinated peptides in early rheumatoid arthritis associate with inflammatory activity and smoking. Arthritis Research \& Therapy. 2016;18(1):119.

II. Roos Ljungberg K, Joshua V, Skogh T, Eklund A, Sköld CM, Karimi R, Nyrén S, Svärd A, Catrina AI, Kastbom A. Secretory anti-citrullinated protein antibodies in serum associate with lung involvement in early rheumatoid arthritis. Rheumatology. 2020;59(4):852-9.

III. Roos Ljungberg K, Börjesson E, Martinsson K, Wetterö J, Kastbom A, Svärd A. Presence of salivary IgA anti-citrullinated protein antibodies associate with higher disease activity in patients with rheumatoid arthritis. Arthritis Research \& Therapy. 2020;22(1):274.

IV. Roos Ljungberg K, Martinsson K, Wetterö J, Svärd A, Kastbom A. Circulating anti-citrullinated protein antibodies containing secretory component are prognostic for arthritis onset in at-risk patients. Clinical \& Experimental Immunology. 2021;204(3):344-51.

Papers I and III are reproduced with permission from Springer Nature. Paper II is reprinted under license from Oxford University Press. Paper IV is reproduced with permission from John Wiley and Sons. All the papers have been published as Open Access articles. 


\section{Introduction}

\section{Rheumatoid arthritis}

Rheumatoid arthritis (RA) is a chronic autoimmune disease of unknown etiology and a prevalence of $0.5 \%-1.0 \%$. A higher prevalence of RA is seen in native American-Indians ( $5 \%-7 \%$ ) and a lower prevalence is seen in African and Asian populations (0.2\%-0.3\%) (1). The disease occurs 2-4-times more frequently in females (2).

\section{Clinical features and classification}

RA is an inflammatory disease that mostly affects the joints, although comorbidities and extra-articular manifestations, such as rheumatoid nodules, pulmonary involvement, and vasculitis, are also part of the clinical manifestations (3). Patients with RA often present with symmetric joint inflammation, typically with pain and swelling of the wrists and metacarpophalangeal, metatarsophalangeal, and proximal interphalangeal joints. Both small and large joints (e.g., knee, ankle, elbow, shoulder) can be affected by synovitis. Morning stiffness, lasting from 30 minutes up to several hours, is a common symptom of RA. If not adequately treated, the patient can develop irreversible joint damage (e.g., erosions, periarticular osteopenia, joint space narrowing), which results in disability and decreased quality of life (4).

To diagnose RA, the gold standard is clinical examination. Classification criteria, which are used to compose well-defined study populations in research studies, can also be used in diagnostics for RA. The American College of Rheumatology (ACR) 1987 criteria (5) have been criticized for the fact that early disease is not captured, and as a consequence of this, the start of effective treatment can be delayed. In 2010, the ACR and European League Against Rheumatism (EULAR) established the 2010 ACR/EULAR classification criteria for RA. These more-recent classification criteria include joint evaluation, symptom duration, serologic testing [for rheumatoid factor (RF) or anti-citrullinated protein antibodies (ACPA)], and measures of acute-phase response [C-reactive protein (CRP) or erythrocyte sedimentation rate (ESR) levels] (Table 1). The 2010 ACR/EULAR classification criteria are used to classify those individuals with definite RA who have a score $\geq 6$ (scoring range is from $o$ to 10) (6). 
Table 1 The 2010 ACR/EULAR classification criteria for rheumatoid arthritis (RA). A score of $\geq 6$ out of 10 (after summing the scores for categories $A-D$ ) is needed for designation of a patient as having definite RA. Modified after Aletaha et al. (6).

\begin{tabular}{|c|c|c|}
\hline & Category & Score \\
\hline \multirow[t]{6}{*}{$\boldsymbol{A}$} & Joint involvement & \\
\hline & 1 large joint & o \\
\hline & 2-10 large joints & 1 \\
\hline & 1-3 small joints & 2 \\
\hline & 4-10 small joints & 3 \\
\hline & $>10$ joints (at least 1 small joint) & 5 \\
\hline \multirow[t]{4}{*}{$\boldsymbol{B}$} & Serology & \\
\hline & Negative RF and negative ACPA & o \\
\hline & Low-positive RF or low-positive ACPA & 2 \\
\hline & High-positive RF or high-positive ACPA & 3 \\
\hline \multirow[t]{3}{*}{$\boldsymbol{C}$} & Acute-phase reactants & \\
\hline & Normal CRP or ESR & o \\
\hline & Abnormal CRP or ESR & 1 \\
\hline \multirow[t]{3}{*}{$\boldsymbol{D}$} & Duration of symptoms & \\
\hline & $<6$ weeks & o \\
\hline & $\geq 6$ weeks & 1 \\
\hline
\end{tabular}

Abbreviations: $R F$, rheumatoid factor; ACPA, anti-citrullinated protein antibodies; CRP, C-reactive protein; ESR, erythrocyte sedimentation rate.

\section{Autoantibodies}

Various circulating autoantibodies have been identified in patients with RA (7), and in the 2010 ACR/EULAR classification criteria both ACPA and RF are included (6). "Seropositive" RA is the term used for patients with a positive RF and/or ACPA test. Today, ACPA analysis has replaced $\mathrm{RF}$ testing as the diagnostic marker of choice in primary care settings (7). 
Rheumatoid factor (RF)

$\mathrm{RF}$ autoantibodies target the fragment crystallizable ( $\mathrm{Fc})$-part of immunoglobulin (Ig)G. Waaler et al. reported in 1940 that mixing RA serum and IgG-sensitized sheep erythrocytes resulted in cell agglutination and inhibition of hemolysis (8). Currently used tests mainly detect RF of the IgM isotype with antigen-specificity for antibodies against the IgG-Fc parts (9). For RA, the sensitivity of the agglutination test (IgM RF) varies from $77 \%$ to $88 \%$ and the specificity is in the range of $67 \%-81 \%(10)$. Alternative methods to detect RF have been developed (including enzyme-linked immunosorbent assays (ELISAs), radioimmunoassays, and nephelometry techniques), and assays to detect IgA RF and IgG RF are available but are not used in clinical practice $(9,11)$. RF can be detected in patients who are suffering from other autoimmune or infectious diseases, as well as in the healthy population where up to $5 \%$ are positive for $\mathrm{RF}$ (9).

Anti-citrullinated protein antibodies (ACPA)

ACPA are antibodies against citrullinated epitopes of modified proteins (12). During citrullination (Figure 1), a post-translational modification of the protein occurs, where arginine is transformed into the amino acid citrulline by peptidylarginine deiminase $(\mathrm{PAD})(12,13)$. In humans, five isoenzymes of PAD (PAD1, PAD2, PAD3, PAD4 and PAD6) exist (14). Citrullination is a physiologic process that is calcium-dependent, and high concentrations of calcium are present during cell activation, cell differentiation, inflammatory responses, ageing processes, keratinization, and cell death. Although ACPA have a high specificity for RA, the citrullination process is unspecific. Citrullination affects the protein structure and can promote the generation of neoantigens and autoimmune responses $(13,15)$. 


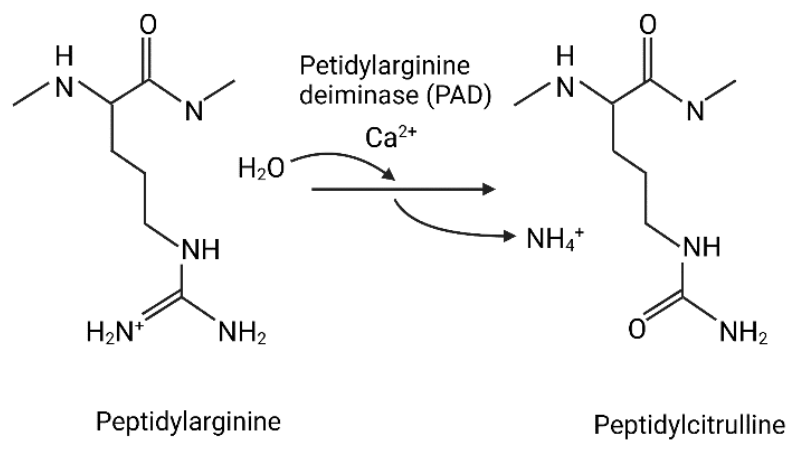

Figure 1 The process of citrullination where arginine residues enzymatically convert to citrulline residues during the action of calcium dependent peptidylarginine deiminase (PAD).

In 1964, Nienhuis et al. described an antibody against human keratohyalin granules of buccal mucosa cells, which was named antiperinuclear factor (APF) (16). Young et al. identified anti-keratin antibodies (AKA) 15 years later (17), and subsequently both APF and AKA were discovered to be antibodies directed against citrullinated filaggrin peptides $(12,18)$. ACPA have also been reported in other diseases, such as systemic lupus erythematosus, Sjögren's syndrome, psoriatic arthritis, vasculitis, and juvenile idiopathic arthritis, although the significance of ACPA in these diseases remains unclear $(9,19,20)$. In patients with systemic lupus erythematosus, the subpopulation with ACPA was found to have more synovitis and bone erosions, i.e., a phenotype that resembled RA (21).

In 2000, the first commercially available ACPA test based on an ELISA technique was developed using synthetic cyclic citrullinated peptide (CCP) derived from human filaggrin (first-generation or anti-CCP1) (22). A second-generation anti-CCP test (anti-CCP2), which was launched in 2002, is commonly used as a routine test for ACPA in RA and is available from various manufacturers $(23,24)$. A third-generation $\mathrm{CCP}$ test (anti-CCP3) was developed subsequently. Compared to CCP2, it includes additional epitopes that are presented in a conformational array to increase epitope exposure. $\mathrm{CCP}_{3}$ may have higher predictive value for RA development in patients with undifferentiated inflammatory arthritis $(9,25-27)$. The CCP3.1 test has the ability to detect both IgA and IgG ACPA (27), and not just IgG ACPA as is the case for the second-generation anti-CCP tests.

Serologic testing for IgG anti-CCP is both a diagnostic and a prognostic tool for RA, with higher diagnostic specificity and similar sensitivity as RF. IgG ACPA is present in $60 \%-80 \%$ of RA patients and the test has 
a specificity of 95\%-99\%. ACPA are rarely detected in the healthy population (13). In a meta-analysis of established RA (28), the pooled sensitivity of ACPA for RA was found to be $67 \%$ and the pooled specificity was $95 \%$, and in an alternative meta-analysis in which early RA patients were also included (29), the CCP2-test had a sensitivity of $72 \%$ and a specificity of $95 \%$. Anti-CCP antibodies were detected in 6\% of non-RA controls and $1 \%$ of healthy controls (29). Different antibody isotypes of ACPA have been identified but only IgG ACPA are used in the clinical routine, where it is associated with radiographic progression and predicts the disease course $(30,31)$. IgA ACPA are present in 30\%-50\% of patients with $\mathrm{RA}$ and are associated with a more aggressive disease, as well as smoking, but not with the risk gene human leukocyte antigen (HLA)-DRB1 shared epitope (SE) (32-34).

ACPA are present locally in the synovial fluid and when comparing the levels of ACPA with reactivities to citrullinated fibrinogen, $\alpha$-enolase, type 2 collagen and vimentin, higher proportions are seen in the synovial fluid after normalization to total IgG, which could be interpreted as local production or retention of ACPA at sites of inflammation (35).

The pathogenetic roles of citrullinated peptides and autoantibodies directed against citrullinated peptides are still unclear. ACPA are associated with the development of RA in healthy individuals $(36,37)$, and their presence is associated with radiographic progression and a moreaggressive disease course $(30,38,39)$. Anti-CCP2 antibodies have been reported to activate complement through the classical and alternative pathways, and immune complexes that contain citrullinated fibrinogen can co-stimulate macrophages $(40,41)$. In terms of animal models, the collagen-induced arthritis (CIA) mouse model is the most generally used model to study RA development due to its similar pathogenesis to human RA (42). In murine models of CIA, it has been demonstrated that the production of anti-CCP and anti-collagen antibodies precedes the appearance of arthritis and that ACPA enhance tissue injury (43). Another possibility is that ACPA are bystanders without intrinsic pathogenic properties, occurring as a consequence of other cellular or humoral processes during RA development (23).

\section{Anti-modified protein autoantibodies (AMPA)}

Apart from ACPA, antibodies that react with proteins that have other post-translational modifications have been reported in RA, and collectively they are called anti-modified protein autoantibodies (AMPA). In RA, proteins with post-translational modifications caused by carbamylation, acetylation, and malondialdehyde modification have been de- 
scribed (44). Anti-carbamylated protein (anti-CarP) antibodies are directed against carbamylated proteins such as the post-translationally modified amino acid homocitrulline. Anti-CarP are described both in ACPA positive and ACPA negative patients, and in ACPA negative patients anti-CarP are associated with radiologic progression (45). AntiCarP are present in patients who ultimately develop RA, with increasing levels appearing after the development of symptoms (46). In newly diagnosed cases of RA, carbamylated and acetylated reactivities are primarily seen in ACPA positive patients and reactivity to malondialdehyde-acetaldehyde is higher in patients with RA than in control subjects, but not RA-specific (47).

\section{Etiopathogenesis}

Both genetic and environmental risk factors for developing RA have been identified (48). In addition, dietary, reproductive and lifestyle-associated factors have been implicated in the pathogenesis of RA (49). In 1983, Thomas et al. showed a familial aggregation of RA, in that $22 \%$ of the study population had a first-degree relative (FDR) with the same disease, and associations with other autoimmune diseases (e.g., type 1 diabetes) were observed (50). When studying FDRs, a heritability rate of $40 \%$ has been demonstrated, and in twin studies heritability has been estimated at $60 \%$ (51). Later studies have demonstrated an odds ratio (OR) of 3 for the FDRs of patients with RA (52) and in twin studies monozygotic twins have a higher risk of developing RA compared to dizygotic twins (53). SE, which is a five amino acid sequence motif coded by the HLA-DRB1 allele (residues 70-74 of the HLA-DR $\beta$ chain) located within the major histocompatibility complex region on chromosome 6 , is associated with RA $(54,55)$.

Cigarette smoking is the furthermost well-documented environmental risk factor for RA, and a meta-analysis has concluded that smokers with 1 to 10 pack-years have a 26\% increased risk of developing RA (relative risk, 1.26), while patients with 20 pack-years or more have double this risk (relative risk, 1.94), as compared to never smokers (56). The risks of ACPA positive and ACPA negative RA are increased with smoking, although the risk is more-pronounced in ACPA positive RA (OR 1.9 versus 1.3 for ACPA negative RA) (57). Smoking cessation over 20 years is not associated with a higher risk of ACPA negative RA; in contrast, for ACPA positive disease, there is a persistent risk of developing RA and the risk is dependent upon the cumulative dose of smoking (57).

Smoking and SE genes interact and this increases the risk of RA, in that smokers with double SE copies have a 21-fold increased risk of developing RA compared to never smokers who do not carry any SE genes 
(58). A dose-response-dependent association has been reported for the increased risk of ACPA positive RA. Among those carrying two copies of $\mathrm{SE}, 55 \%$ of the risk is attributed to smoking (59).

\section{Preclinical period}

Autoantibodies associated with RA can be detected in the circulation for a long time before any clinical signs of arthritis appear $(60,61)$. Retrospectively, this is called the 'preclinical period' $(62,63)$. The preclinical period is indicative of induction sites of RA inflammation outside of the synovial joints, and several studies have shown that ACPA and/or RF is a risk factor for future development of RA $(37,64)$. Understanding the events that occur in the preclinical-RA period leading up to a definite RA diagnosis would facilitate the development of therapies to prevent RA $(65,66)$.

During the development of RA, typical stages are observed. In prospective studies, recommendations as to the definitions of these phases have been discussed in consensus meetings. The patients can be described as exhibiting specific disease features in the following sequence (Figure 2): (1) genetics; (2) environmental triggers; (3) systemic autoimmunity; (4) symptoms not related to clinical arthritis; (5) unspecified arthritis; and (6) definite RA (62). 


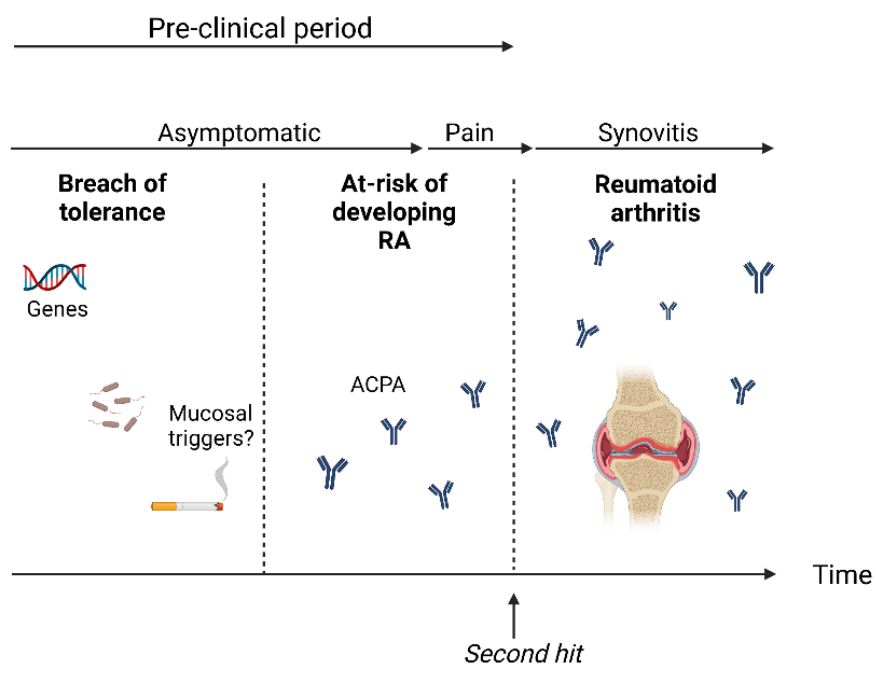

Figure 2 Progression from at-risk individuals to rheumatoid arthritis (RA). A breach of tolerance occurs in asymptomatic phases in genetically predisposed individuals, possibly at mucosal linings (cigarette smoking, oral pathogens). Anti-citrullinated protein antibodies (ACPA) occur during the pre-clinical period as a sign of a systemic autoimmune reaction. Closer to definite $R A$, the levels and diversity of ACPA increase, and after an unknown trigger (i.e., second hit) arthritis develops. Modified after

Catrina et al. (67).

Even before autoantibodies are detectable in the circulation, signs of activation of the immune system, e.g., increased levels of cytokines and chemokines, can be detected in the circulation (68-70). Accumulation of autoantibody specificities during the process of epitope spreading has also been reported (71), in the absence of synovial inflammation $(60,61)$. Examination of the synovium of the knee joint during the preclinical period has revealed that even though autoantibodies are detected in the circulation no synovitis is evident (61).

The levels of autoantibodies and the percentages of positivity for RArelated autoantibodies increase as the patient approaches RA diagnosis $(36,37)$. Not all ACPA positive individuals develop RA, and the patients who ultimately develop RA have higher autoantibody levels, as well as an increase in isotype diversity (72). The risk of developing RA for asymptomatic individuals and a positive ACPA test has been documented (absolute risk of $5 \%-16 \%(36,37)$ ), although the risk increases further if joint or musculoskeletal symptoms are also present (64, 73-75). In patients with clinically suspected arthralgia, ACPA and RF have an additive value in predicting arthritis, with ACPA conferring the highest risk (76). Moreover, ACPA levels, as well as the concurrent presence of RF, have been shown to predict arthritis in symptomatic, at-risk patients (77). 


\section{The mucosal immune system}

Mucosal surfaces are spread throughout the body, serving as a boundary between the interior and exterior of the body. The major mucosal linings are located in the oral cavity, the airways, the gastrointestinal system, and the urogenital tract. Mucosa-associated lymphoid tissue (MALT) is lymphoid tissue that is located in proximity to the mucosal surfaces and has the ability to sample antigens and initiate immune responses. MALT contains B cell follicles, antigen-presenting cells (macrophages and dendritic cells) and T cell zones, which resemble lymph nodes. In the mucosal epithelium, specialized microfold (M) cells bind to exogenous antigens and actively transport them through the epithelium to bring them into contact with professional antigen-presenting cells $(78,79)$. The MALT is divided into effector sites and inductive sites. At inductive sites (e.g., gut-associated lymphoid tissue, bronchus-associated lymphoid tissue), IgA class switching occurs and there is clonal expansion of B cells due to $\mathrm{T}$ cell activation (antigen-specific activation). The $\mathrm{T}$ and $\mathrm{B}$ cells migrate to effector sites located in all the mucosal tissues as disseminated lymphoid tissues, where transepithelial IgA transportation occurs (80).

In mammals, the production of IgA is an essential part of mucosal immunity, and IgA is the antibody with the highest production rate in the body (78). High levels of mucosal IgA are found in the gastrointestinal tract, saliva, tears, breast milk, nasal fluids, and lung fluids. IgA at mucosal sites is predominately dimeric with an incorporated joining $(\mathrm{J})$ chain $(78,81,82)$. It is produced by submucosal B cells (at effector MALT sites) and is subject to transepithelial transportation after attaching to the polymeric immunoglobulin receptor (PIgR) on the basolateral side of the epithelial cell (Figure 3). During proteolysis, the antibodies are attached to the secretory component (SC) (a part of the former PIgR), thereby forming secretory IgA (SIgA), which is released into the lumen. The SC can also bind to pentameric IgM to form secretory IgM (SIgM) $(78,83)$. SIgA is destined for mucosal secretions, such that the SC stabilizes the dimeric IgA-complex and prevents it from being degraded. 


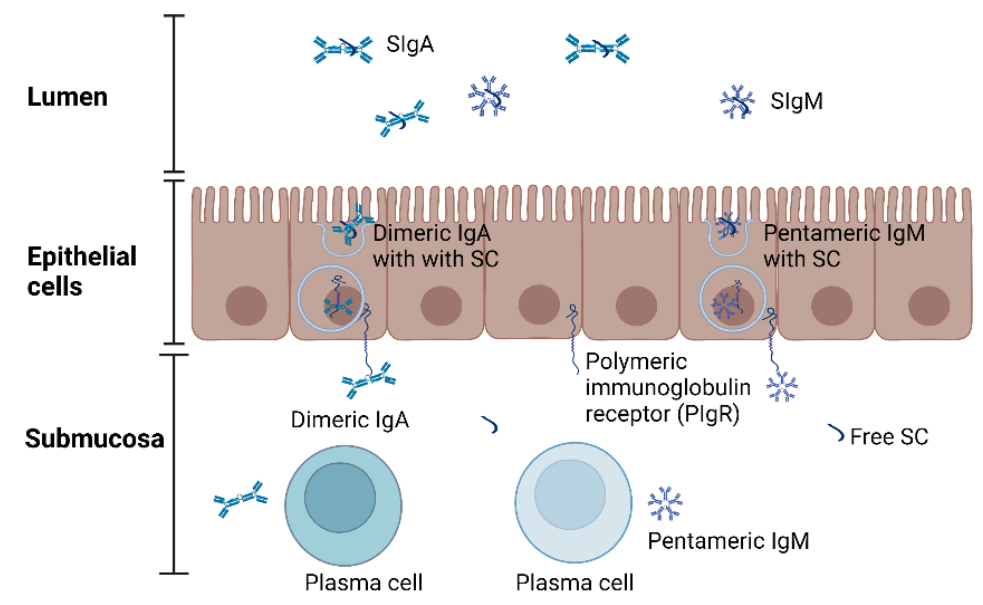

Figure 3 Transepithelial transportation of dimeric IgA and pentameric IgM produced by submucosal plasma cells, by binding to the polymeric immunoglobulin receptor (PIgR). As a result, from proteolysis of the receptor-antibody complex, the antibodies remain attached to the secretory component (SC) (a part of the PIgR), thereby

forming secretory IgA (SIgA) or IgM (SIgM) which are released into the lumen.

SIgA has anti-inflammatory properties, in that it neutralizes bacterial toxins, inhibits bacterial adhesion, and is part of the first line of defense against microbes $(78,84)$. The mucosal immune system acts in an antiinflammatory manner through both immune exclusion by SIgA (limiting epithelial contact and penetration) and immunosuppressive mechanisms directed against luminal antigens that are categorized as innocuous (referred to as 'oral tolerance' in the gastrointestinal tract) $(78,79)$.

Compared to mucosal IgA, serum IgA is not attached to the $\mathrm{J}$ chain or $\mathrm{SC}$ and is predominantly monomeric (85). Even though secretory antibodies are mostly found in secretions, low amounts could be detected in the circulation (86), and antigen-specific secretory antibodies have been reported in the circulation after oral immunization (87).

In humans, IgA exists as two subclasses, IgA1 and IgA2. The subclasses have different distributions in serum and mucosal secretions. IgA1 predominates in the serum, with a 9:1 proportion to IgA2, whereas in secretions the proportion of IgA2 is higher (82). In colostrum, tears, nasal fluids, saliva, and intestinal lavage fluid higher relative amounts of IgA2 have been reported $(82,88,89)$.

There are some previous reports on secretory antibodies in patients with RA. Total SIgA levels have been shown to be increased in patients with RA, and secretory component containing RF (SC RF) has been detected in a subgroup of patients with RA (90). IgA subclasses of RF in the 
serum and synovial fluid are mainly of the IgA1 subclass, whereas in saliva IgA2 RF is more prevalent (91). SC ACPA have not been reported prior to this thesis work.

\section{The mucosal origin hypothesis in $R A$}

The mucosal origin hypothesis in relation to RA proposes that RA is initiated at mucosal sites, where an autoimmune reaction is triggered and thereafter transitions to involve the synovial joints (63). The way in which arthritis is ultimately triggered is still unknown, and cross-reactivity to an antigen in the synovium is a possibility that links pre-clinical ACPA production to the development of definite RA.

Dysbiosis of the microbiota at mucosal sites has been suggested to play a part in the development of RA. Alternations of the microbial flora in the lungs, oral cavity and intestine have been reported both in patients with established RA and in preclinical individuals $(92,93)$. In untreated patients with early RA, the bronchoalveolar lavage fluid (BALF) microbiota has been reported to exhibit lower diversity and abundance than that in healthy controls. The relative abundance of Actinomyces, Burkhodelia, Prevotella and Porphyromonas were reduced, and the only genus that was over-represented in RA BALF was Pseudonocardia, which also correlated to higher disease activity and erosions (94). In the oral cavity, the local microbiome shows similar changes for patients atrisk and early RA patients with a relatively higher incidence of potentially proinflammatory species (e.g., Prevotella, Veillonella, Porphyromonas), as compared to healthy controls (95-97). In early RA patients, Prevotella copri abundance has been reported to be increased in fecal samples and shown to correlate with a reduction in the number of Bacteroides species (98).

At-risk persons, who do not have inflammatory arthritis but are positive for circulating IgG ACPA, have higher proportions of IgA positive peripheral blood plasmablasts (plasma cell precursors (99)), as compared to healthy controls. This difference was not seen for IgG positive plasmablasts, suggesting that RA-related antibodies may ascend from mucosal immune responses during the early stages of the disease. Early RA patients, on the other hand, did not exhibit high frequencies of IgA positive plasmablasts, which could be a result of anti-rheumatic treatment or that the initial mucosal triggering events have already passed (100).

Local ACPA production at mucosal surfaces and secretions have been demonstrated (101-103), although the contribution of each mucosal compartment to the induction of RA development is still not fully understood and could vary from patient to patient. 


\section{The lungs}

Smoking is a known epidemiologic risk factor, primarily for ACPA positive RA, which suggests a connection to the mucosal immunity of the respiratory system (57). Other environmental irritants for the lungs have also been shown to be risk factors for RA (104). Local mucosal inflammation is thought to contribute to the citrullination of proteins in the lungs, and there is a potential to evoke a systemic immune response to these citrullinated proteins in genetically predisposed individuals (105, 106). Induced bronchus-associated lymphoid tissues that contain autoantibody-producing plasma cells have been demonstrated in patients with RA, which may indicate involvement in local RA pathogenesis (107). Furthermore, an association between ACPA positivity and signs of parenchymal and airway abnormalities has been reported in early RA patients and FDRs $(101,108)$. In sputum samples from relatives, ACPA was detected even in serum ACPA negative persons, and the increased counts of neutrophils and macrophages suggest a local respiratory inflammation (109). Induced sputum samples from at-risk patients showed positivity for at least one RA-related autoantibody in $65 \%$ of seropositive individuals, as compared to $39 \%$ of seronegative at-risk persons, and $86 \%$ of early RA patients had autoantibodies in the sputum (103).

Non-RA smokers express citrullinated epitopes in bronchoalveolar lavage cells (58), and patients with chronic obstructive pulmonary disease without RA express higher serum levels of both ACPA and RF, as compared to controls (110). Thus, inflammation caused by cigarette smoking could contribute to the citrullination of self-proteins, inducing a loss of tolerance and the production of neoantigens, which in turn could be presented to $\mathrm{T}$ cells with later activation of $\mathrm{B}$ cells, ultimately leading to the production of ACPA $(71,106)$.

BALF samples from untreated early RA patients show enrichment of ACPA of both IgA and IgG isotype compared to paired serum samples (101). Lymphocyte infiltration in bronchial biopsies is more frequently observed in ACPA positive patients compared to ACPA negative patients and controls (111). Identical citrullinated proteins have been identified in synovial and bronchial biopsies, and they may represent a connecting linkage between the lungs and joints, as RA-related autoantibodies might target these shared citrullinated peptides (112).

Other inhaled irritants have been suggested to cause pulmonary mucosal inflammation, as non-smokers also develop RA. Silica exposure is associated with ACPA positive RA in a dose-response relationship, and in current smokers the risk is even higher, indicating an interaction between silica and smoking $(104,113)$. 


\section{The oral cavity}

The oral mucosa is of interest as a site for mucosal immunization with citrullinated peptides. Over the last 200 years, an association between oral disease and RA has been considered, and at one time tooth extraction was considered a treatment option for RA (114). Periodontitis, which is a chronic inflammatory disease that affects the gums, has been linked to RA (115), although the results are inconsistent (116). Smoking is also an important risk factor for periodontitis, and RA and periodontitis share important pathophysiologic mechanisms (both diseases result in the destruction of soft and hard tissues) (117). In a meta-analysis, an increased risk of RA was observed for patients with periodontitis compared to healthy controls (pooled OR 1.69, 95\% CI 1.31-2.17, p<0.0001) (118).

Periodontitis is caused by a microbial biofilm that consists of several microbes, such as Porphyromonas gingivalis ( $P$. gingivalis), as well as Aggregatibacter actinomycetemcomitans and Treponema denticola have been reported (118). P. gingivalis express a PAD that is not dependent upon calcium, so it has the ability to citrullinate human proteins (117). Citrullinated proteins can be detected in inflamed periodontal tissues and the citrullinating ability of $P$. gingivalis may result in a generalized immune response to citrullinated self-antigens after loss of selftolerance (119-122). The levels of antibodies directed against $P$. gingivalis (anti-Pg) are increased in RA patients $(115,123)$, and in a metaanalysis, the levels of anti-Pg have been reported to be increased particularly among ACPA positive cases (124). In a study of 50 treatment-naïve early RA patients, in those with IgG anti-Pg, the levels of anti-CCP antibodies were higher (125).

When at-risk patients (positive for RA-related antibodies and arthralgia), early RA patients, and controls were compared in a study conducted by Kroese et al., no differences between the groups were observed when performing periodontal examinations (evaluations of presence of bleeding on probing, pocket probing depth or periodontal inflamed surface area) (95). Mankia et al. showed in contrast, that ACPA positive at-risk individuals had higher prevalence rates of periodontitis and $P$. gingivalis compared to controls (126). Comparisons of early RA patients, chronic RA patients, and controls with comparable PD severity have shown that the subgingival microbiota is similar (96). Good oral hygiene instructions decreased the load of periodontal pathogens but did not result in decreased disease activity in established cases of RA (127).

A small study of patients with established RA in Sweden demonstrated the presence of salivary IgA anti-CCP antibodies, as $22 \%$ of the included patients were positive for salivary IgA anti-CCP. This finding was linked to a trend towards lower ESR and CRP levels at the time of 
diagnosis and significantly fewer erosions within 6 years after the RA diagnosis (102).

\section{The gastrointestinal system}

In epidemiologic studies, the relationships between food components and RA have been investigated and the underlying mechanisms have been suggested to be related to alternations in the gut microbiota and an antioxidant effect of the food, although many studies have shown conflicting results (49).

Dysbiosis of the microbiota in the intestine is evident at all stages of RA, although it has not been established if the dysbiosis is causally linked to RA development or if it is a consequence of systemic inflammation. The dysbiosis can initiate intestinal inflammation but it is not clear if the dysbiosis can also promote synovial inflammation (92). In both established RA and pre-RA, altered intestinal permeability occurs. The production of zonulin (peptide family regulating intestinal permeability) induces the disassembly of tight junction proteins, resulting in intestinal barrier dysfunction and the induction of T cell-mediated mucosal inflammation. Higher levels of zonulin have been reported in both established RA and pre-RA cases (128).

Currently, studies of levels of IgA ACPA in the feces of patients with $\mathrm{RA}$ and at-risk individuals are missing. In patients with inflammatory bowel disease, ACPA have been demonstrated in the circulation (mostly of IgA ACPA isotype, but also IgG ACPA albeit below the diagnostic cutoff) and this has been taken as a possible sign that mucosal inflammation of the intestine can induce low systemic levels of ACPA (129).

In a study in which patients with RA received daily high-fiber supplements for 28 days, the numbers of circulating T regulatory cells increased and the levels of markers of bone erosions decreased, whereas the levels of IgG ACPA and IgM RF antibodies did not change significantly (130). Short-chain fatty acids, which are produced during the fermentation of dietary fibers by intestinal microbiota, are important for the barrier function of the intestinal epithelium $(92,128)$. Lower levels of short-chain fatty acids have been noticed to be predictive of progression to clinical arthritis in at-risk individuals (131). 


\begin{abstract}
Aims
The overall aim of this thesis was to characterize the mucosal ACPA responses in RA, with the ultimate purpose of identifying mucosal immune processes that are of pathogenic importance in RA. The hypothesis driving this work is that mucosal immunization and secretory ACPA responses influence RA development and progression. In this thesis, secretory ACPA are investigated in the circulation and in local mucosal secretions in order to: (i) improve the understanding of the mucosal connection in RA; and (ii) investigate whether these antibodies can improve diagnostics and prognostics in early RA.
\end{abstract}

The specific aims were to:

- Investigate the occurrence of circulating secretory ACPA in early RA and, if present, relate the levels of such antibodies to clinical outcomes and risk factors for RA.

- Relate the levels of serum secretory ACPA to the levels in BALF and to signs of lung involvement in early RA.

- Determine the IgA ACPA subclass distributions in serum and saliva and relate these to disease characteristics and risk factors for RA.

- Evaluate the presence and potential prognostic value of secretory ACPA in patients who are at risk of developing RA and who have musculoskeletal pain and IgG ACPA. 


\section{Material and methods}

\section{Study subjects}

In the work of this thesis, several longitudinal and cross-sectional patient cohorts were used (Table 2).

Table 2 Short descriptions of the included patient cohorts.

\begin{tabular}{|c|c|c|c|c|}
\hline & $\begin{array}{l}\text { Number of } \\
\text { patients }\end{array}$ & $\begin{array}{l}\text { Types of patients } \\
\text { included }\end{array}$ & $\begin{array}{l}\text { Inclusion } \\
\text { years }\end{array}$ & $\begin{array}{l}\text { Types of } \\
\text { samples }\end{array}$ \\
\hline TIRA-1 & 317 & $\begin{array}{c}\text { Early RA, } \\
\text { DMARD-naïve }\end{array}$ & $1996-1998$ & Serum \\
\hline TIRA-2 & 452 & $\begin{array}{c}\text { Early RA, } \\
\text { DMARD-naïve }\end{array}$ & $2006-2008$ & Serum \\
\hline LURA & 142 & $\begin{array}{c}\text { Early RA, } \\
\text { DMARD-naïve }\end{array}$ & 2007-2012 & $\begin{array}{l}\text { Serum, } \\
\text { BALF, } \\
\text { bronchial } \\
\text { biopsies }\end{array}$ \\
\hline$S A R A$ & 196 & $\begin{array}{l}\text { Established RA, 96\% } \\
\text { treated with DMARD }\end{array}$ & 2012-2013 & $\begin{array}{l}\text { Saliva, } \\
\text { serum }\end{array}$ \\
\hline TIRx & 82 & $\begin{array}{c}\text { IgG ACPA positive } \\
\text { musculoskeletal pain, } \\
\text { no immunomodulatory } \\
\text { treatment }\end{array}$ & 2010-2013 & Serum \\
\hline
\end{tabular}

Abbreviations: RA, rheumatoid arthritis; DMARD, disease-modifying anti-rheumatic drug; BALF, bronchoalveolar lavage fluid; ACPA, anti-citrullinated protein antibodies.

Timely interventions in RA (TIRA)-1 and -2 studies

The prospective, multicenter TIRA-1 cohort enrolled patients between 1996 and 1998. Patients were recruited from the southeast of Sweden at 10 different rheumatology clinics. At inclusion, patients had a symptom duration of $\geq 6$ months but $<12$ months since the first swollen joint. Patients had at least four out of seven of the 1987 revised ACR criteria (5) 
for RA or morning stiffness for $\geq 60$ minutes and symmetrical arthritis and small joint arthritis. Patients were excluded if they had serious liver or renal disease, a previous history of joint swelling or RF negative psoriasis. Longitudinal assessment of disease activity (DAS28) (132), inflammatory factor measurements, functional ability scoring [Swedish version of health assessment questionnaire (HAQ) (133)], clinical examination [swollen (SJC) and tender joint counts (TJC)], and treatment were all obtained at each follow-up visit. Serial serum samples were collected at the follow-up visits for 8 years after inclusion in the study. In total, 317 patients were included in TIRA-1 and from 62\% (N=197) baseline serum samples were available (30).

TIRA-2 was executed in the same manner as TIRA-1, except that the patients were enrolled between 2006 and 2008. In this multicenter, prospective study, yearly radiographs of the hand and feet were performed (up to 3 years after inclusion) and graded using the Larsen scoring system (134). Otherwise, the follow-up strategy was the same as for TIRA-1 (disease activity scores, laboratory measurements, treatment registration etc.). In total, 452 patients were included in TIRA-2 and from 97\% $(\mathrm{N}=439)$ baseline serum samples were available (135).

In both TIRA-1 and TIRA-2, all the participants signed a written informed consent, and the study protocols were approved by the Regional Ethics Review Board in Linköping.

\section{Lung investigation in newly diagnosed $R A$ (LURA) study}

The cross-sectional LURA study was performed at Karolinska University Hospital in Stockholm, Sweden. The included patients were referred from primary care centers due to self-reported joint difficulties with a symptom duration of 2-16 months. Enrolment was carried out in the period 2007-2012. Exclusion criteria were treatment with glucocorticoids, conventional disease-modifying anti-rheumatic drugs (DMARDs) or biologic agents. In total, 142 patients were included, 106 of whom underwent high-resolution computed tomography (HRCT), pulmonary functions tests, and measurements of diffusion capacity for carbon monoxide. HRCT was executed within 1 week after diagnosis, and the findings were categorized as parenchymal abnormalities (nodules larger than 3 $\mathrm{mm}$, ground-glass opacities, fibrosis, opacities, or emphysema) and airway abnormalities (air trapping, bronchiectasis, or bronchial wall thickening). Twenty patients underwent BALF sampling and bronchial biopsies. Control BALF samples were obtained from 10 patients with sarcoidosis and 3 healthy controls (101).

Participants gave their written informed consent, and the Regional Ethics Review Board in Stockholm approved the study protocol. 


\section{Secretory ACPA in RA (SARA) study}

The SARA study is a cross-sectional observational study of established RA patients in the County of Dalarna, Sweden. Enrolment was carried out in the period of 2012-2013, and patients with RA were randomly selected from the Rheumatology Clinic in Falun during planned follow-up visits. Exclusion criteria to the study was known hyposalivation. Paired serum and saliva samples were collected. In total, 196 patients with RA were included, as well as 101 healthy blood donors as controls.

Information regarding radiographic damage was obtained by chart review. At the follow-up visit, at which saliva and serum samples were obtained, SJC, TJC, DAS28, HAQ and patient global assessment (PGA) were performed. Serum was analyzed regarding inflammatory parameters and antibodies. At inclusion, the participants provided information regarding smoking habits and dental health through answering a questionnaire (136).

All participants signed a written informed consent, and the Regional Ethics Review Board in Uppsala approved the study protocol.

\section{Extra-early rheumatology follow-up (TIRx) study}

The prospective observational cohort study TIRx (Swedish term for "extra-early rheumatology follow-up") was conducted at the University Hospital in Linköping, Sweden. Enrollment was carried out during the period of 2010-2013, and patients were referred from primary care centers in the County of Östergötland. Inclusion criteria were a positive IgG anti$\mathrm{CCP} 2$ serum test in clinical routine and musculoskeletal pain. Exclusion from the study was based on either previous rheumatic inflammatory disease or corticosteroid treatment (intra-articular or oral) within 6 weeks prior to screening. Regular follow-up visits included serum sampling, clinical examination, ultrasonographic examination, and radiographs of the hands and feet (at baseline and after 1 and 2 years). Development of arthritis was defined by an experienced rheumatologist by clinical examination. If participants experienced worsening of symptoms, patients were offered additional clinical examinations, as well as serum sampling. In total, 82 patients with no baseline arthritis were included in TIRx. As controls for the antibody analysis and ultrasonographic examination, one-hundred healthy blood donors were recruited (77).

All participants provided written informed consent, and the Regional Ethics Review Board in Linköping approved the study protocol. 


\section{Laboratory methods}

\section{Sampling}

Serum samples from the different cohorts (Papers I-IV) were analyzed for antibodies and various biomarkers of inflammation. The serum was centrifuged and then stored at between $-70^{\circ} \mathrm{C}$ and $-80^{\circ} \mathrm{C}$ until further laboratory work.

Sampling of $B A L F$ (Paper II) was performed at the Karolinska University Hospital by the instillation of $250 \mathrm{~mL}$ of phosphate-buffered saline (PBS) into a middle lobe bronchus. All of the BALF were pooled, and no BALF samples were discarded. At the same procedure, bronchial mucosal biopsies were acquired from the segmental and sub-segmental septa of the left lung. BALF and biopsy specimens were stored at $-80^{\circ} \mathrm{C}$. In the BALF, the total number of cells were counted, and cell differentials were scored (using cytospins stained with May-Grünwald Giemsa). Hematoxylin and eosin staining was used for standard histology of the biopsies. To evaluate the biopsies for activation-induced cytidine deaminase, T cells, B cells, dendric cells, plasma cells, macrophages, PAD2, PAD4 and HLA-DR/DQ (immune cell activation markers), immunohistochemistry was performed.

Saliva (Paper III) was collected at the Rheumatology Clinic in Falun, Sweden, by passive secretion, whereby the study participant tilted forward and drooled into a test tube. Patients were asked to abstain from brushing their teeth, eating, drinking liquids (exception for water), or smoking 1 hour before saliva sampling. The participants provided saliva during a 10-minute sampling period, and for participation in the study at least $0.5 \mathrm{~mL}$ of saliva was required. The saliva sample was immediately placed on ice. The mucus fibers in the saliva sample were disrupted by pipetting the sample several times, followed by centrifugation for 5 minutes at $5,000 \times g$. The supernatant was stored at $-80^{\circ} \mathrm{C}$.

\section{Antibody analyses}

ELISAs were used for the antibody analyses in all the subprojects of this thesis. A commercially available immunoassay with second-generation $\mathrm{CCP}$ as antigen (CCPlus, Immunoscan; EuroDiagnostica AB, Malmö, Sweden) was used to detect IgG ACPA. This assay was modified to detect IgA, IgA1, IgA2, IgM, and SC ACPA, respectively, in serum as well as in saliva. In Papers I, II and IV, fluoroenzyme immunoassays were used to detect serum IgG and/or IgA ACPA using the PhaDia 250 instrument (EliA; Thermo Fisher AB, Uppsala, Sweden) and CCP2 as the antigen. 
All samples were re-analyzed if the coefficient of variation exceeded 20\% between the duplicate samples (both serum, BALF and saliva were analyzed in duplicate). Incubation and washing were performed according to the directives of the manufacturer. Table 3 summarizes the features of the immunoassays used in this project.

Table 3 Summary of enzyme-linked immunosorbent assay (ELISA) methodologies used in the thesis.

\begin{tabular}{|c|c|c|c|}
\hline $\begin{array}{c}\text { ACPA } \\
\text { isotype }\end{array}$ & $\begin{array}{l}\text { Type of patient } \\
\text { sample }\end{array}$ & $\begin{array}{c}\text { Dilution of patient } \\
\text { sample }\end{array}$ & $\begin{array}{c}\text { Dilution of secondary } \\
\text { antibody }\end{array}$ \\
\hline$S C$ & Serum & $1: 25$ & 1:2000 \\
\hline $\operatorname{IgG}$ & Serum & $1: 50$ & $\begin{array}{l}\text { Provided by the } \\
\text { manufacturer }\end{array}$ \\
\hline $\operatorname{IgA}$ & Serum & $1: 100$ & 1:2000 \\
\hline $\operatorname{IgA1}$ & Serum & $1: 50$ & 1:500 \\
\hline $\operatorname{IgA2}$ & Serum & $1: 50$ & $1: 400$ \\
\hline $\operatorname{Ig} M$ & Serum & 1:25 & 1:10 000 \\
\hline$S C$ & BALF & Undiluted & $1: 500$ \\
\hline $\operatorname{IgA}$ & Saliva & $1: 20$ & $1: 200$ \\
\hline $\operatorname{IgA1}$ & Saliva & $1: 20$ & 1:300 \\
\hline $\operatorname{IgA2}$ & Saliva & 1:20 & 1:300 \\
\hline
\end{tabular}

Abbreviations: ACPA, anti-citrullinated protein antibodies; SC, secretory component containing, BALF, bronchoalveolar lavage fluid. 
Serum

SCACPA

A polyclonal goat IgG anti-human secretory component antibody (GAHu/SC/PO; Nordic Biosite AB, Täby, Sweden) was used as the secondary antibody. A high-level serum sample of SC ACPA was used in a serial dilution sequence to create a standard curve (dilution series: 1:12.5 to $1: 800$ ). The standard curve was then used to calculate the results in arbitrary units per milliliter (AU/mL). Cut-offs were set to the $99^{\text {th }}$ percentile of healthy controls, in Papers I and II to $\geq 153 \mathrm{AU} / \mathrm{mL}$, in Paper III to $\geq 72 \mathrm{AU} / \mathrm{mL}$, and in Paper IV to $\geq 124 \mathrm{AU} / \mathrm{mL}$ (different cut-offs based on different control materials).

IgGACPA

IgG ACPA were analyzed either as instructed by the manufacturer of the ELISA kit, and a cut-off level set to $\geq 25 \mathrm{AU} / \mathrm{mL}$ (Papers I-III), or by fluoroenzyme immunoassay on the PhaDia instrument with a cut-off level of $\geq 7 \mathrm{U} / \mathrm{mL}$ (Paper IV). In Paper I, the TIRA-1 sera were analyzed by enzyme immunoassay (EIA) (Immunoscan RA CCP2; EuroDiagnostica, Arnhem, The Netherlands) with a cut-off set by the manufacturer at $\geq 25 \mathrm{AU} / \mathrm{mL}$.

IgA ACPA

IgA ACPA were analyzed by the same procedure in Paper I (TIRA-1) and Paper III. The secondary antibody was replaced by a horseradish peroxidase-conjugated polyclonal rabbit anti-human a-chain antibody (DakoCytomation, Glostrup, Denmark). A high-level IgA ACPA serum sample served to create the standard curve, with the results being calculated in $\mathrm{AU} / \mathrm{mL}$. Based on the $99^{\text {th }}$ percentile among 80 controls, the cutoff was defined at $\geq 25 \mathrm{AU} / \mathrm{mL}$. In Papers I (TIRA-2), II and IV, IgA ACPA were analyzed using a fluoroenzyme immunoassay, and the secondary antibody was a mouse anti-human IgA antibody that could detect both subclasses. The cut-offs were set at $\geq 2 \mu \mathrm{g} / \mathrm{L}$ (Papers I and II) and $\geq 12 \mathrm{U} / \mathrm{mL}$ (Paper IV), according to the $99^{\text {th }}$ percentile among controls.

\section{$\operatorname{IgA1}$ and IgA2 ACPA}

In the IgA1 and IgA2 ACPA assays, the secondary antibodies were antiIgA1/IgA2 polyclonal mouse IgG anti-human Fc-region-specific antibodies conjugated with horseradish peroxidase (No. ABIN135642/No. ABIN135646; Antibodies Online, Aachen, Germany). High-level serum samples were used as a reference and used in a seven-step serial dilution series. Cut-offs were set at $\geq 27 \mathrm{AU} / \mathrm{mL}$ for IgA1 ACPA and $\geq 179 \mathrm{AU} / \mathrm{mL}$ for IgA2 ACPA, generated from the $99^{\text {th }}$ percentile among 101 controls. 


\section{IgM ACPA}

In the IgM ACPA assay, a polyclonal goat anti-human secondary antibody directed against the heavy chain conjugated to horseradish peroxidase (Nordic Biosite AB, Täby, Sweden) was used. A known high-level serum sample of IgM ACPA was used to create a standard curve. The cutoff limit was set at $\geq 322 \mathrm{AU} / \mathrm{mL}$ based on the $99^{\text {th }}$ percentile among 100 controls.

\section{$B A L F$}

BALF samples were analyzed according to the same SC ACPA protocol as was used for serum to detect SC ACPA, albeit with slight modifications concerning the dilutions (Table 3). The secondary antibody used, was the same as in the serum SC ACPA assay in Paper I (GAHu/SC/PO; Nordic Biosite), and the same procedure was done for calculating the standard curve. Three standard deviations among 13 BALF samples from controls was used to set the cut-off limit at $\geq 138 \mathrm{AU} / \mathrm{mL}$.

\section{Saliva}

The same commercially available immunoassays with second-generation $\mathrm{CCP}$ as antigen (CCPlus, Immunoscan; EuroDiagnostica AB, Malmö, Sweden) were used for the saliva analyses. In addition, all the saliva samples were examined for reactivity with a non-citrullinated control peptide, cyclic arginine peptide (CAP), to correct for non-specific IgA adsorption (kindly provided by EuroDiagnostica $\mathrm{AB}$ ). The analyses were performed in parallel for anti-CCP and anti-CAP, and the results are displayed in optical density (OD) values. The results are presented as antiCAP levels subtracted from the anti-CCP values.

The saliva samples were thawed at room temperature and to remove non-soluble material, the samples were centrifuged at $15,000 \times g$ at $4^{\circ} \mathrm{C}$ for 10 minutes. IgA ACPA were detected with the same secondary antibody as in the serum IgA ACPA analysis (DakoCytomation). In the IgA1 and IgA2 ACPA assays, the secondary antibodies were the same as those in the serum IgA1/IgA2 ACPA analyses (No. ABIN135642/No. ABIN135646; Antibodies Online). The cut-off values for the salivary assays were set at 0.78 for IgA ACPA, 0.70 for IgA1 ACPA, and 0.39 for IgA2 ACPA, based on the $99^{\text {th }}$ percentile among 101 blood donors. 


\section{Western blot analysis}

Affinity chromatography was used to isolate IgA and IgG anti-CCP from a high-level serum sample (using a CCP column; EuroDiagnostica AB). Western blot detection of SC was performed for the affinity-purified fractions of IgG and IgA, respectively, to verify the occurrence of circulating SC ACPA. The purified antibodies were diluted and added to a 10\% sodium dodecyl sulfate-polyacrylamide gel electrophoresis (SDS-PAGE) gel (Bio-Rad Laboratories, Hercules, CA, USA). Electrophoresis was performed at $180 \mathrm{~V}$ for 90 minutes. The proteins were then transferred to a presoaked nitrocellulose membrane with Towbin buffer. Blotting was performed at $80 \mathrm{~V}$ for 30 minutes (Bio-Rad PowerPac HC; Bio-Rad Laboratories). Washing and blocking of the membrane, using $5 \%$ fat-free milk power, were performed for 60 minutes, whereafter the membrane was placed 5 minutes in Tris-buffered saline (TBS) with $0.05 \%$ Tween20. After being excised from the gel, the molecular marker was incubated for 30 minutes with the same detection antibody as in the serum SC ACPA assay (GAHu/SC/PO; Nordic Biosite AB) diluted 1:60,00o in TBSTween (TBS-T). The remainder of the membrane was incubated overnight with the secondary antibody (diluted 1:50,000). Washing of the membrane was done with TBS-T and TBS and then incubation with substrate (ECL Prime Western Blotting Detection Reagent; GE Healthcare Life Sciences, Little Chalfont, UK) for 1 minute. Thereafter, exposure (high-performance chemiluminescence film; GE Healthcare Life Sciences) for 1 minute was performed followed by development of the film (by D-19 Silver and Fixer; Kodak, Rochester, NY, USA). 


\section{Statistical analysis}

In this thesis, mostly non-parametric statistical tests have been used because the antibody levels were not normally distributed and/or the sample sizes were too small to use parametric tests. In all the analyses, twosided p-values < 0.05 were considered statistically significant. In Paper I, we used last observation carried forward to correct for missing values. Results were excluded if missing values occurred during the first, moredynamic 6 months.

The Mann-Whitney $U$-test was applied to compare patients who were positive versus negative for: the different ACPA isotypes analyzed in this project regarding the levels of other ACPAs, clinical and laboratory measurements of disease severity, cell scores, pulmonary function tests, cigarette smoking pack-years, HAQ, PGA and changes in ACPA levels (net and relative changes) (Papers I-IV).

Student's $t$-test were used to compare SC ACPA positive and negative patients in Paper I, as this patient material was sufficiently large $(\mathrm{N}=636)$.

Correlations were assessed with Spearman's rho correlation given the non-normal distribution of the data (Papers I-IV).

Linear regression analysis was used to evaluate the associations between SC ACPA and the different variables, e.g., ESR and adjusting for age, gender and SE, and number of pack-years adjusting for age. The association between disease activity and the levels of salivary IgA ACPA was evaluated with linear regression analysis (with adjustments for serum IgA ACPA, treatment, and disease duration) (Papers I-III).

Logistic regression analysis was performed in the same way as the linear regression but for categorical variables. To evaluate the association of lung changes with SC ACPA, we adjusted the calculations for age, sex, and smoking status (Papers I and II).

Fisher's exact test was used to test categorical variables for differences in the occurrence of, e.g., smoking and SE, in the different ACPA isotype groups (Papers I-IV).

Wilcoxon's signed-rank test was applied to evaluate changes in levels of ACPA (Paper IV).

Cox regression analysis was performed to calculate the prognostic values of SC ACPA and other ACPA isotypes, RF, risk factors and clinical variables, with the development of arthritis as the outcome (Paper IV). 


\section{Results and Discussion}

\section{Occurrence of secretory ACPA}

The novel finding of secretory ACPA in serum has not been described previously. In this thesis, circulating SC ACPA are detected in early RA patients (Papers I and II), established RA patients (Paper III), and prior to arthritis onset (Paper IV). The mere presence of SC ACPA is indicative of activation of the immune system at mucosal linings, as this isotype is formed by submucosal B cells and binds to the PIgR on epithelial cells. Thus, it strengthens the mucosal origin hypothesis for RA and connects autoantibody production to the mucosa. Subsequent to the publication of Paper I, van Delft and colleagues confirmed our finding, and also showed that circulating secretory ACPA were predominantly of the IgM isotype (137), and not the IgA isotype as we assumed in Paper I. Given this finding, the term SC ACPA will be used in the Results and Discussion section instead of the term SIgA anti-CCP used in Paper I. The modified ELISA described in the four subprojects of this thesis detects SC containing ACPA and is capable of detecting both SIgA and SIgM.

To evaluate the citrulline-dependent specificity of SC ACPA, we analyzed 10 IgG ACPA positive serum samples for CAP reactivity. No OD value for SC CAP exceeded 40\% of the SC CCP OD value. The median OD for SC anti-CAP was 0.09, as compared to 0.83 for SC anti-CCP (Figure 4a). To confirm the ELISA finding of SC ACPA in the serum, we also performed a Western blot analysis. In the IgA anti-CCP fraction (but not in the IgG fraction), an 80-kDa band, corresponding to the molecular mass of SC (78), was apparent. Thus, we concluded the presence of SC ACPA in serum.

\section{Circulation}

In Paper I, the occurrence of circulating SC ACPA was confirmed by two different methods, and $17 \%(\mathrm{~N}=110)$ of the early RA patients in the TIRA cohorts were positive for circulating SC ACPA by ELISA (Figure 4b). Only a subpopulation of the included participants was positive for circulating SC ACPA, the vast majority of whom were also positive for IgG ACPA, reflecting a systemic autoimmune reaction (only two patients in the TIRA cohorts were SC ACPA positive and IgG ACPA negative). SC 
ACPA were detected in $25 \%$ of the IgG ACPA positive patients, as compared to the detection of IgA ACPA in 39\% of the IgG ACPA positive patients.

a

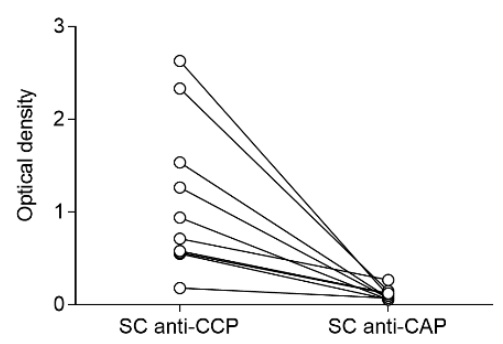

b

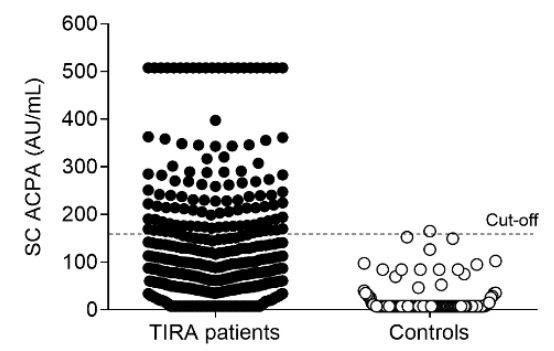

Figure 4 Secretory component $(S C)$ reactivities to cyclic citrullinated peptide (CCP) and cyclic arginine peptide (CAP) (a) and levels of SC anti-citrullinated protein antibodies (ACPA) in the TIRA patients and controls (b). Modified from Paper I.

The prevalence of circulating SC ACPA in established RA patients was 21\% ( $\mathrm{N}=42)$ (Paper III), and in at-risk patients, all of whom were IgG ACPA positive, SC ACPA were detected in 21\% $(\mathrm{N}=17)$ at baseline (Paper IV). This is a higher prevalence compared to that reported in another study of at-risk individuals in which FDRs were analyzed for SC ACPA in plasma and only $1 \%$ were found to be positive. Among the FDRs with a positive SC ACPA test for plasma, all were positive for conventional ACPA, indicating that a systemic ACPA response had already been established (138). In the TIRx cohort, all the patients were symptomatic compared to the FDRs of the patients with RA, which suggests that SC ACPA are important for triggering arthritis development but not for the progress of a systemic ACPA response.

\section{Lungs}

In the LURA cohort, $16 \%(\mathrm{~N}=23)$ of the included patients tested positive for circulating SC ACPA (Paper II). SC ACPA were found in 35\% $(\mathrm{N}=7)$ of the BALF samples. All the BALF SC ACPA positive patients were positive for serum IgG and IgA ACPA, and serum SC ACPA co-occurred in $57 \%$ of these patients. BALF SC ACPA correlated with the levels of all circulating ACPA isotypes tested $(\mathrm{r}=0.55$ for $\operatorname{IgG}, \mathrm{r}=0.75$ for IgA, and $\mathrm{r}=0.50$ for SC ACPA). 


\section{Oral cavity}

In Paper III, we analyzed IgA ACPA and its subclasses, IgA1 and IgA2. Specific IgA1 and IgA2 subclasses of CCP have not been reported previously. In the circulation, IgA1 ACPA were present in $44 \%(\mathrm{~N}=86)$ and IgA2 ACPA in 39\% $(\mathrm{N}=76)$ of the SARA patients (Figure 5a). Compared to a study looking at circulating IgA subclasses of RF, where IgA1 RF was reported to be more common compared to IgA2 RF (73\% vs. 36\%) (91), patients with RA seem to have relatively more IgA2 ACPA. We speculate that mucosal immunization to citrullinated proteins may be more prominent in compartments that exhibit IgA2 dominance, e.g., lower gastrointestinal tract $(88,139)$. Circulating IgA, IgA1 and IgA2 ACPA occurred almost exclusively in patients who had IgG ACPA.

Salivary IgA ACPA presumably represent secretory isotype, as SIgA is one of two major antibodies in saliva, with IgG being the other (140). Overall, $12 \%(\mathrm{~N}=24)$ of the SARA patients tested positive for salivary IgA ACPA. We also characterized the subclass profile in the saliva, and found that $10 \%(\mathrm{~N}=19)$ were positive for salivary IgA1 ACPA and 9\% $(\mathrm{N}=18)$ were positive for salivary IgA2 ACPA (Figure $5 \mathrm{~b}$ ). 

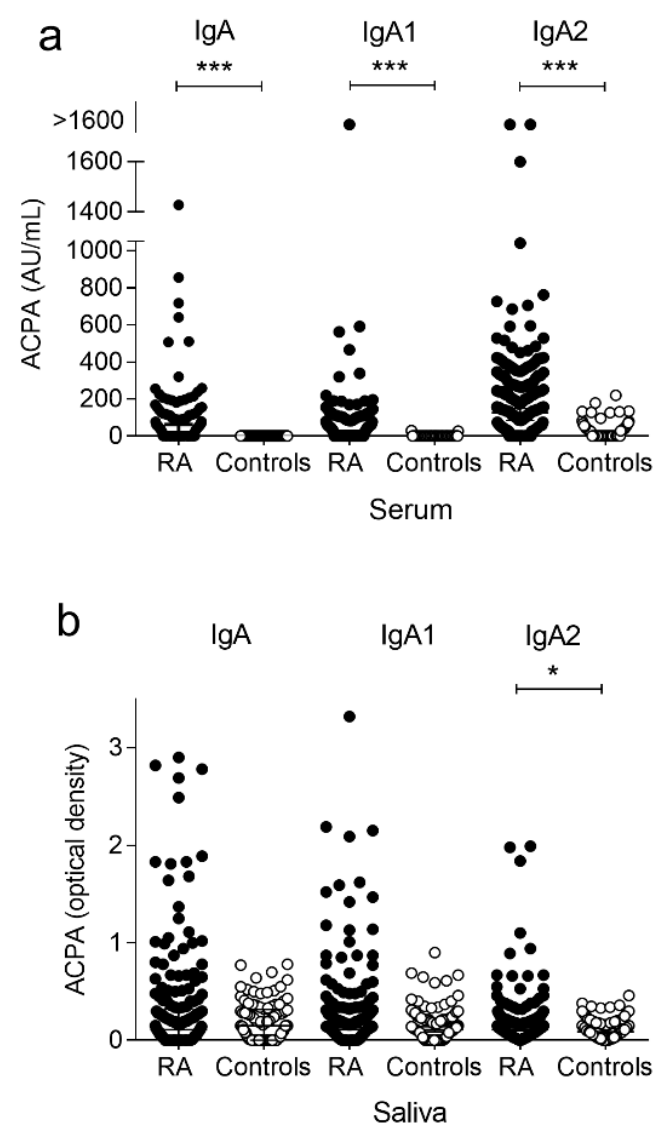

Figure 5 Levels of IgA, IgA1 and IgA2 anti-citrullinated protein antibodies (ACPA) in serum (a) and saliva (b) in established rheumatoid arthritis ( $R A)$ patients and controls in the SARA cohort. ${ }^{*} p<0.05 ;{ }^{* *} p<0.001$. Modified from Paper III.

\section{Circulating versus mucosal secretory ACPA}

The correlations between the SC ACPA levels in different compartments were moderate (for BALF vs. serum SC ACPA: $r=0.5, p=0.027$; for salivary IgA ACPA vs. serum SC ACPA: $r=0.29, p<0.001)$. Since secretory ACPA in the circulation theoretically reflect the existence of ACPA at mucosal linings, we had assumed a stronger correlation.

Circulating SC ACPA have been reported to be mostly of the IgM isotype, and free SC correlates more strongly with IgM ACPA than with IgA ACPA $(137,141)$, which could explain the rather weak correlation we observed between salivary IgA ACPA and circulating SC ACPA. Another 
possible explanation is that other mucosal linings, apart from the oral cavity, contribute to the circulating SC ACPA and they have not been analyzed in these studies. The mechanism by which mucosal ACPA reach the circulation is not investigated in this project, although active transport across the mucosal membrane is a possibility $(142,143)$. An alternative mechanism for translocation to the circulation is passive transportation over leaky, inflamed mucosal membranes. Importantly, we found no association between the use of non-steroidal anti-inflammatory drugs (NSAID) and SC ACPA levels in early RA patients, rendering it less likely that there was iatrogenic damage to the mucosal linings (Paper I). 


\section{Secretory ACPA versus risk factors for RA}

\section{Smoking}

Smoking was associated with SC ACPA in the circulation in both early and established RA patients and in at-risk patients. In TIRA (Paper I), SC ACPA were associated with smoking when comparing SC ACPA positive and negative patients who were still IgG ACPA positive, higher proportion of ever smokers were reported in SC ACPA positive patients (Figure 6). After adjusting for age, sex, and SE, the association with smoking was still present (OR 2.19, 95\% CI 1.01-4.37, $\mathrm{p}=0.027$ ).

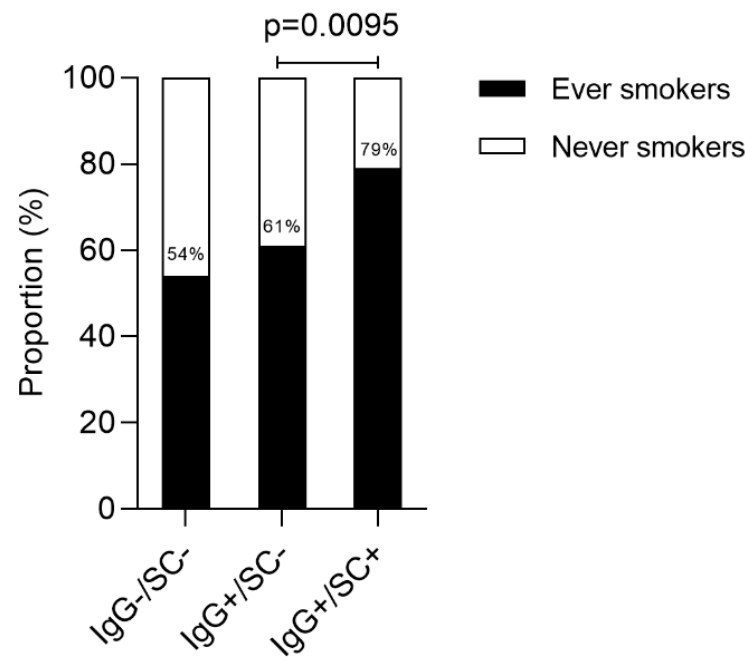

Figure 6 Smoking habits of the TIRA patients in relation to secretory component containing (SC) and IgG anti-citrullinated protein antibody (ACPA) status. Modified from Paper $\boldsymbol{I}$.

In the treatment-naïve LURA patients (Paper II), ever smoking was more common among the serum SC ACPA positive patients ( $91 \%$ vs. $67 \%, \mathrm{p}=0.023$ ), and these patients also had higher numbers of packyears. When comparing ever smokers and never smokers, the circulating SC and IgA ACPA levels (but not the levels of IgG ACPA) were significantly higher in the ever smokers (Figure 7). 


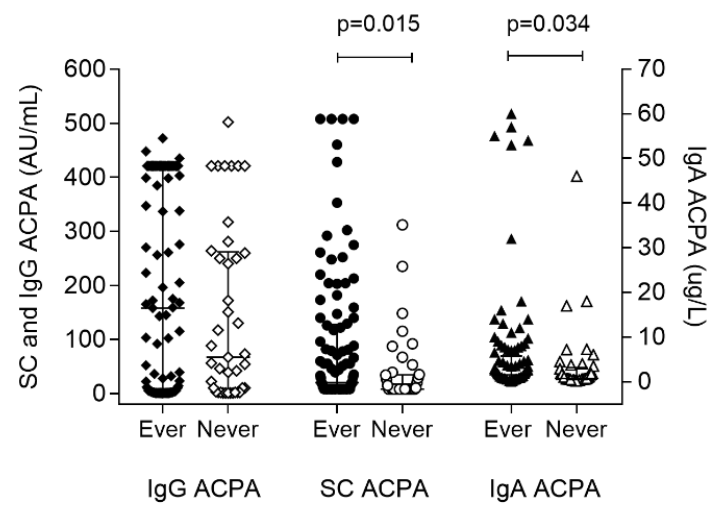

Figure 7 Levels of circulating IgG, secretory component containing (SC), and IgA anti-citrullinated protein antibodies (ACPA) in ever smokers and never smokers in the LURA cohort. Modified from Paper II.

Regarding salivary IgA ACPA, we found no associations with smoking habits. In the serum samples of the SARA patients, no differences were discovered regarding smoking status, although the numbers of packyears were higher in the IgA, IgA1 and SC ACPA positive patients (Paper III). In the SARA cohort, only $8 \%(\mathrm{~N}=15)$ were current smokers, which could partly explain why no statistically significant associations between smoking status and circulating IgA or SC ACPA were seen. We did not observe any association between smoking and mucosal SC ACPA in either the BALF or IgA ACPA in the saliva, perhaps due to the fact that only a few patients were positive for SC ACPA in BALF and for salivary IgA ACPA, i.e., a statistical power issue. The levels of total SIgA (i.e., not antigen-specific) in saliva are lower in smokers (144), and this could possibly influence the levels of IgA ACPA in samples of saliva.

In Paper IV, TIRx patients who were ever smokers had higher levels of SC ACPA at baseline (median 66 vs. $25 \mathrm{AU} / \mathrm{mL}, \mathrm{p}=0.035$ ) but this was not the case for any of the other ACPA isotypes. Taken together, the studies show that circulating SC ACPA are clearly related to smoking, while no such association could be established concerning the mucosal samples.

\section{Genetic predisposition (shared epitope)}

Unlike IgG ACPA, SC ACPA was not associated with the genetic risk factor SE (145). This is in line with findings concerning IgA ACPA in serum, which are also associated with smoking but not with SE $(33,34)$. This finding was confirmed in both early and established RA patients. 


\section{Secretory ACPA versus RA manifestations}

\section{Secretory ACPA versus disease activity}

Circulating SC ACPA are associated with systemic inflammation, as both the ESR and CRP levels were higher in patients who were positive for SC ACPA (Paper I). However, there was no correlation between SC ACPA and joint inflammation, as assessed by SJC or TJC. This could be interpreted as SC ACPA have pro-inflammatory properties outside the joints, perhaps contributing to an ongoing inflammation at the mucosal linings. During a 3-year follow-up period, the ESR levels remained higher in the SC ACPA positive patients, even after adjustment for age (a known confounder for ESR) (Figure 8). There were no differences in the proportions prescribed DMARDs or NSAID between the SC ACPA positive and negative patients, so these treatments do not account for the differences in inflammatory activity observed between the two groups.

In Paper II, we showed that the BALF SC ACPA levels correlated with the serum levels of CRP $(r=0.45, p=0.047)$.

\footnotetext{
- SC ACPA positive $\square \quad$ SC ACPA negative
}

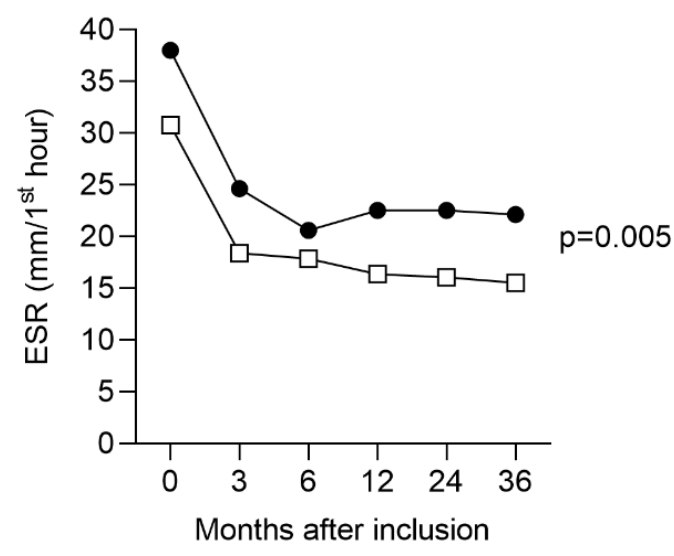

Figure 8 Mean erythrocyte sedimentation rate (ESR) values during a 3-year disease course for the secretory component containing $(S C)$ anti-citrullinated protein antibody $(A C P A)$ positive $(N=80)$ and $S C A C P A$ negative $(N=243)$ patients in the TIRA cohorts. Modified from Paper I. 
Among the established SARA patients, those who were positive for SC ACPA had higher ESR, CRP and DAS28, as well as worse functional disability at the time of sampling, indicating that SC ACPA is of importance for inflammatory activity even in patients with longstanding RA with ongoing anti-rheumatic treatment (Paper III). In contrast to the early RA patients (33), circulating IgA ACPA did not associate with increased disease activity in established RA patients, but rather to functional disability, as judged by HAQ and PGA scores.

\section{Secretory ACPA and the lungs}

From the HRCT images acquired from the patients, airway abnormalities were detected in $64 \%(\mathrm{~N}=68)$ and parenchymal abnormalities in $55 \%$ $(\mathrm{N}=58)$, with the latter being associated with serum SC ACPA levels even after adjustment for age, sex, and smoking (OR 1.4, 95\% CI 1.03-1.93, $\mathrm{p}=0.034$ ) (Figure 9a). The serum levels of IgA ACPA were also higher in this group, although no difference was seen considering IgG ACPA. Bronchiectasis detected in HRCT images was associated with higher levels of serum SC ACPA (Figure 9b) but not with higher levels of IgG or IgA ACPA. The association between circulating SC ACPA and bronchiectasis persisted after adjustments for age, sex, and smoking (OR 1.6, 95\% CI 1.06-2.39, $\mathrm{p}=0.026)$. Bronchiectasis with chronic bacterial infection is associated with the presence of RF (146), and in established RA, bronchiectasis is reported to be associated with higher levels of IgG ACPA and $\mathrm{RF}$ as well as higher disease activity scores (147). In the present study, RA-related autoantibodies of the secretory isotype were raised in patients with bronchiectasis, which indicates a connection to the lungs in cases of RA.

SC ACPA in BALF or serum samples was not associated with pulmonary function, diffusion capacity for carbon monoxide or cell counts in the BALF. In bronchial biopsies, patients who were positive for BALF SC ACPA had higher scores of HLA-DQ, which may indicate a local immune activation. We did not find higher numbers of infiltrating lymphocytes in either the BALF or serum SC ACPA positive patients, in contrast to what was previously reported regarding IgG ACPA positive patients $(101,111)$.

Thus, circulating SC ACPA are associated with radiologic lung abnormalities in early RA, and SC ACPA are demonstrated locally in the BALF. 
a

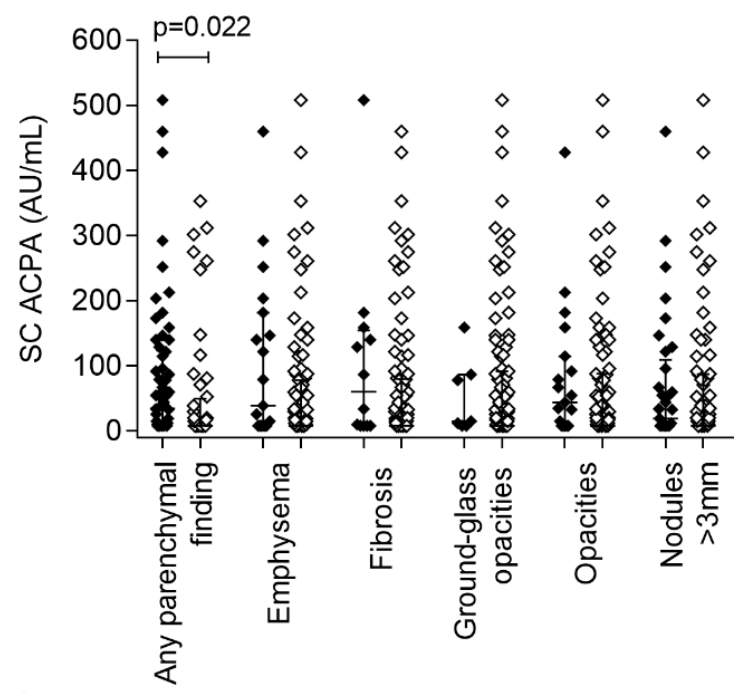

b

- Visible HRCT abnormality

$\diamond \quad$ No visible HRCT abnormality

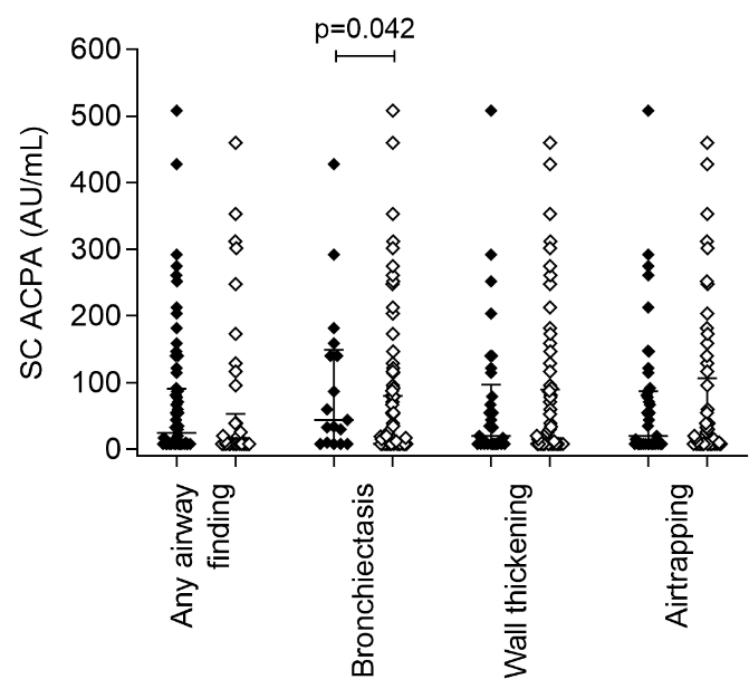

Figure 9 Serum secretory component containing (SC) anti-citrullinated protein antibody (ACPA) levels and high-resolution computed tomography (HRCT) findings for the parenchyma (a) and airways (b) of patients in the LURA cohort. Modified from Paper II. 


\section{IgA ACPA and the oral cavity}

Patients who were positive for salivary IgA ACPA had higher disease activities in terms of higher ESR, DAS28 and TJC, as well as higher functional ability scores (HAQ) and patient-reported outcome measures (PGA). Similar findings were observed for salivary IgA1 ACPA but not for salivary IgA2 ACPA (Figure 10). DAS28 was associated with the levels of salivary IgA ACPA also in a regression analysis in which adjustments were made for disease duration and treatment (biologic agents and/or glucocorticoids).

a

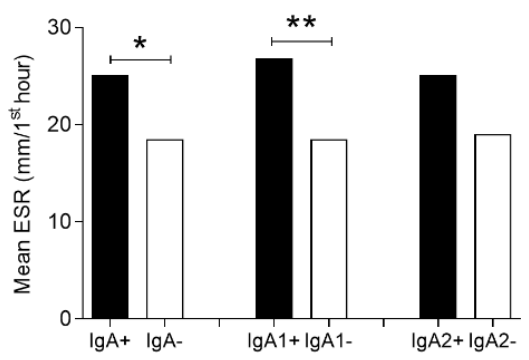

C

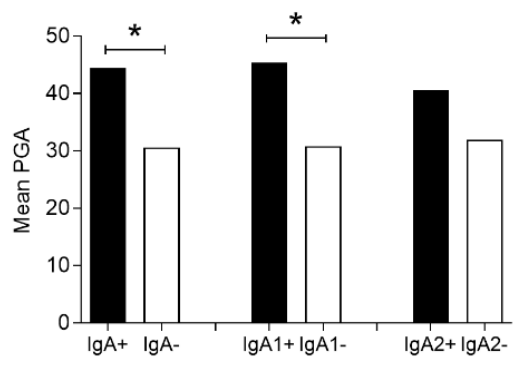

b

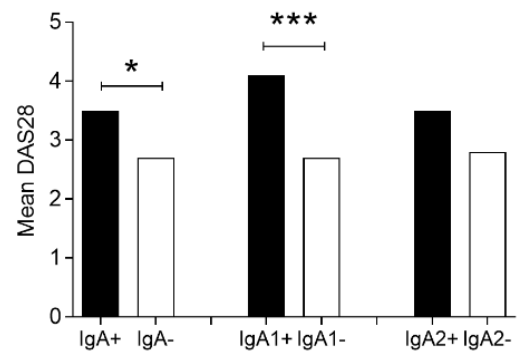

d

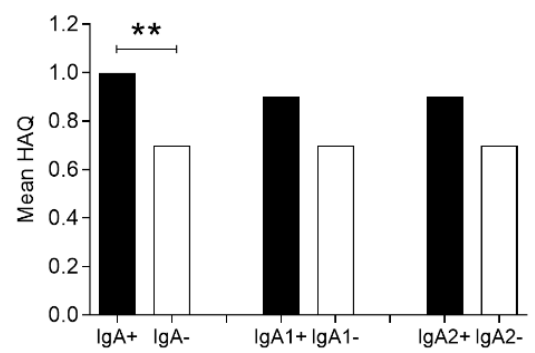

Figure 10 Disease characteristics versus salivary IgA, IgA1 and IgA2 anti-citrullinated protein antibody (ACPA) status regarding erythrocyte sedimentation rate (ESR) (a), disease activity score (DAS) 28 (b), patient global assessment (PGA) (c), and health assessment questionnarie (HAQ) (d) for the patients in the SARA cohort. ${ }^{*} p<0.05 ;{ }^{* *} p<0.01 ;{ }^{* * *} p<0.001$. Modified from Paper III. 
There was no correlation between the rate of saliva secretion and the levels of salivary IgA ACPA ( $\mathrm{r}=-0.099, \mathrm{p}=0.217)$, so the secretory rate is unlikely to exert a major impact on the levels of salivary IgA ACPA.

In this large confirmation study on the presence of salivary IgA ACPA, we could not verify the previously reported association with milder disease (102). Instead, we show that patients with a positive salivary IgA ACPA test have higher disease activity, and that salivary IgA ACPA seem to be more closely associated with disease activity than with circulating IgA ACPA.

\section{Secretory ACPA and radiographic outcomes}

IgG ACPA have been reported to be associated with worse radiologic outcome $(38,39,148)$. However, we could not replicate this finding regarding circulating SC ACPA, neither in early RA cases, as no difference was seen regarding radiologic outcome over the 3-year follow-up (Paper I), nor in established RA cases (Paper III).

Salivary IgA ACPA were not associated with radiologic outcome, so the previous finding of fewer joint erosions within 6 years after diagnosis (102) was not replicated in the present study.

\section{Prognostic value of secretory ACPA}

We also assessed the prognostic value of different ACPA isotypes in an IgG ACPA positive, at-risk population (Paper IV). During follow-up, $48 \%(\mathrm{~N}=39)$ of the at-risk patients developed at least one arthritic joint after a median of 6 months.

The prognostic value of IgG ACPA levels has previously been reported for the TIRx cohort (77). As a novel finding in the present study, we show that levels of circulating SC ACPA predict arthritis onset (Paper IV). In a multivariable Cox regression analysis, in which only statistically significant variables from the univariable Cox regression analysis were included, we showed that the baseline levels of SC ACPA are prognostic for arthritis development, even though RF and IgG ACPA were included in the analysis (HR 1.006, 95\% CI 1.002-1.011, p=0.008) (Table 4). 
Table 4 Multivariable Cox regression analysis of at-risk patients, with baseline factors versus arthritis development.

\begin{tabular}{lll}
\hline & HR $(95 \% \mathrm{CI})$ & p-value \\
\hline RF level & $1.000(0.995-1.005)$ & 0.966 \\
IgG ACPA level $(\boldsymbol{U} / \mathbf{m L})$ & $0.999(0.998-1.001)$ & 0.371 \\
IgA ACPA level $(\boldsymbol{U} / \mathbf{m L})$ & $0.986(0.967-1.005)$ & 0.153 \\
IgM ACPA level $(\boldsymbol{A U} / \mathbf{m L})$ & $1.000(1.000-1.000)$ & 0.168 \\
SCACPA level $(\boldsymbol{A U} / \mathbf{m L})$ & $\mathbf{1 . 0 0 6}(1.002-1.011)$ & $\mathbf{0 . 0 0 8}$ \\
DAS28 & $1.225(0.861-1.744)$ & 0.259 \\
CRP $(\mathbf{m g} / \mathbf{L})$ & $1.028(0.937-1.128)$ & 0.553 \\
\hline
\end{tabular}

Abbreviations: HR, Hazard ratio; RF, rheumatoid factor; ACPA, anti-citrullinated protein antibodies; SC, secretory component containing; DAS28, Disease Activity Score 28; CRP, C-reactive protein.

Although we found that the levels of circulating SC ACPA had prognostic value, the SC ACPA status did not. To define a level of SC ACPA that constitutes a higher risk for developing RA is an important objective for future studies, as clinicians are used to define a sample as pathologic if it is above a pre-defined cut-off. If it can be confirmed in larger, at-risk populations that SC ACPA-positivity predicts arthritis development this ACPA isotype analysis might be considered for implementation in clinical care settings.

In the at-risk population studied in Paper IV, we did not see any alterations in the levels of any of the ACPA isotypes as arthritis developed, and a change of ACPA status was rarely seen. We hypothesized that the levels of SC ACPA would increase closer to the onset of arthritis, as this ACPA isotype is thought to relate to mucosal inflammation. It is possible that the most pronounced increase in SC ACPA had already occurred before inclusion in the study, as most of the patients developed arthritis shortly (at a median of 6 months) after the baseline measurement. 


\section{Mucosal pathogenesis}

In this project, we have studied mucosa-related antibodies, as SC containing ACPA are of mucosal origin. Two different mucosal secretions have been demonstrated to harbor SC ACPA (BALF) and IgA ACPA (saliva), and these are a sign of local production of secretory autoantibodies in RA.

Circulating levels of SC ACPA are associated with BALF levels of SC ACPA, with smoking and with HRCT abnormalities in the lung, suggesting links between the lungs and mucosal ACPA in cases of RA. Chronic irritation from smoking causes a non-specific inflammation, which can disrupt the mucosal lining and enable the transportation of local SC ACPA from the BALF into the circulation. Smoking causes increases in local inflammation and citrullination (149). Citrullination has been reported in in lung tissue samples of patients with chronic obstructive pulmonary disease, as compared to healthy individuals (110, 150). Inflammation caused by cigarette smoking, other airway irritants or inflammatory diseases in the airways can contribute to the citrullination of proteins in the lungs, the creation of neoantigens, and the induction of a systemic immune response, resulting in ACPA production in predisposed persons. Patients with RA and interstitial lung disease have been reported to have higher ACPA levels compared to patients who are not suffering from interstitial lung disease (151). We found that patients with specific abnormalities on HRCT had higher levels of circulating SC ACPA (Paper II), making it interesting to speculate that mucosa-associated antibody formation shares pathologic processes with structural lung changes, and that this phenomenon does not simply reflect an increased capacity of secretory antibodies to migrate to the circulation in patients with lung changes. The observed strong association with smoking, not only regarding the higher proportions of ever smokers in several of the included patient cohorts, but also the higher levels of ACPA in ever smokers and higher number of pack-years, indicates an association between SC ACPA and the local mucosal immune system in the lungs. We propose that the association between SC ACPA and smoking (in early RA patients and at-risk persons), and not genetic predisposition, indicates that mucosal inflammation in the airways is important for the pathogenesis of ACPA positive disease.

Salivary ACPA have previously been reported by our research group, and we have confirmed the presence of salivary IgA ACPA in a larger patient material (Paper III). We now see the opposite result in patients who are positive for salivary IgA and IgA1 ACPA, showing an association to a more clinically active disease, as compared with the results of the previous pilot study. In addition, we found a lower prevalence of salivary 
IgA ACPA (102). Salivary ACPA have also been reported by Demoruelle and colleagues, who used the CCP3.1 method to detect salivary ACPA and showed that $30 \%$ of the tested saliva samples from patients with RA were positive for CCP3.1 ACPA (152). In FDRs, salivary IgA ACPA were not present (compared to $12 \%$ of patients with RA from the same cohort (138)). When stratifying patients with RA based on the presence of periodontitis, as detected in a dental examination, Svärd et al. reported that $20 \%$ of patients with RA and periodontitis had IgA ACPA in the saliva, as compared with $55 \%$ of patients with RA with no periodontitis (statistically non-significant difference). Furthermore, the levels of IgA ACPA in the saliva were not higher in the periodontitis group, which indicates that periodontitis does not increase the local production of salivary IgA ACPA by the oral mucosa (153). In our study of salivary IgA ACPA, we did not consider oral health status or the load of periodontitis-related pathogens, though it is possible that these factors contribute to the more clinically active disease that we found in salivary IgA and IgA1 ACPA positive patients. Our findings suggest that mucosal immune responses to citrullinated proteins in the oral cavity are of importance in ACPA positive RA pathogenesis.

Moderate correlations between the serum and BALF or saliva levels of SC/IgA ACPA levels indicate that these mucosal compartments are partly reflected in serum samples, although several compartments are likely to be involved in the constitution of the circulating SC ACPA content. In addition, different mucosal compartments may contribute to different fractions of circulating SC ACPA depending on the patient. 


\section{Methodologic issues}

Give that it is well-established that IgG ACPA predict the disease outcome $(30,39)$ and may impact the therapeutic choices by the treating rheumatologist, we chose to investigate only the clinical outcome, disease activity, smoking habits, radiologic outcome and SE status of SC and IgA ACPA isotype in IgG ACPA positive patients in Papers I and III. This decision was made to minimize the bias associated with being IgG ACPA positive. In Paper II, the patients were treatment-naïve and, in this study, we did not make the exclusion to only investigate IgG positive patients regarding clinical outcome and smoking habits. This was a cross-sectional study of early RA patients, and IgG ACPA were not expected to have an impact on the outcome. In Paper IV, all the included patients were IgG ACPA positive.

Different cut-off levels of SC ACPA were used in the subprojects in this thesis because SC ACPA were analyzed in different laboratories, different control materials were used, and different samples were collected in the different studies. In Paper I, 101 controls (50\% women; all blood donors) from the same geographic area as the TIRA-1 and TIRA-2 patients were used. For the SARA cohort, a specific control material (53\% women; mean age, 49 years) were recruited, as these participants also donated saliva samples and were from the same geographic area as the patients with RA from the outpatient clinic in Falun (Paper III). The same rationale applies to the TIRx controls (50\% women; mean age, 52 years), who were matched for age, recruited from the same geographic area as the at-risk patients, and had their joints examined by ultrasonography (Paper IV).

One could argue that the presence of SC ACPA reflects not only mucosal immune activation, since extra-mucosal formation of secretory immunoglobulins has been demonstrated by our research group (154). However, free SC is a product of the epithelial cells at effector sites in the MALT, so there is still a connection to the mucosal lining even though the SC can form secretory immunoglobulins outside the mucosa by binding to IgA and/or IgM in the circulation. Moreover, SC binds to dimeric IgA, which is more-strongly associated with the mucosal lining than monomeric IgA (78).

The BALF samples were analyzed in an undiluted state, otherwise the antibody reactivity was decreased in the ELISA. In this study, we did not correct the BALF for different dilution properties during sampling; this could have been done by correcting the SC ACPA value to the total protein or urea content in the BALF (155). However, as this methodology was not used for the analyses of IgG and IgA ACPA in BALF samples from the same patient cohort (101) we chose not to do so for SC ACPA as well. 
Analysis of secretory autoantibodies in serum samples could offer an alternative and more-feasible way to study mucosal immunity, as the serum is considered to reflect the combined inflammatory status of the mucosal linings in a single sample. Moreover, the sampling of mucosal secretions is technically more challenging. Saliva sampling is difficult to perform in a standardized way. In this study, all the participants were instructed to restrain from eating, brushing teeth, smoking or drinking (with the exception of drinking water) at least 1 hour before the sampling. The same handling procedure was executed for all saliva samples: immediately placing the saliva sample on ice and directly after centrifugation aliquoting and freezing the sample, as it is known that storage temperature is important for the preservation of immunoglobulins in saliva samples (156). The salivary secretion rate affects the levels of antibodies in the saliva (157). Therefore, we used passive secretion of saliva to minimize the risk of dilution of antibodies in the saliva (compared to stimulating saliva for sampling). We did not see, however, that the salivary secretion rate correlated with levels of salivary IgA ACPA.

To avoid non-specific binding in the salivary analyses, we corrected for this by measuring CAP at the same time as we measured CCP reactivity. In this study, we used a different approach to determinate the cut-off for salivary IgA ACPA, which might explain why we reported fewer patients with RA who were positive for salivary IgA ACPA compared to the pilot study. Instead of calculating ratios of citrulline-specific reactions to CAP-unspecific reactions, we used delta calculations because we concluded that patients who had higher reactivity to the control peptide compared to CCP did not have CCP-specific antibodies in their saliva. If the same cut-off strategy would have been used in this study as in the pilot study (using the CCP/CAP ratio and the $95^{\text {th }}$ percentile among the healthy blood donors as the cut-off (102)), 13\% of the RA patients would have been classified as salivary IgA ACPA positive. The low number of positive patients seen in the salivary IgA ACPA assays may reflect the fact that the control subjects were younger than the patients with RA, which may have affected the cut-off levels for IgA ACPA, since age influences the IgA levels (158). 


\section{Clinical implications}

- Considering the low sensitivity of SC ACPA (irrespective of compartment), and that it occurs almost exclusively in IgG ACPA positive patients, IgG ACPA testing in serum is still recommended for diagnostic purposes.

- In this thesis, we did not observe worse outcomes among patients with RA concerning radiologic joint damage or disease activity scores for patients who were positive for circulating SC ACPA or salivary IgA ACPA. Therefore, routine testing of RA patients in clinical practice cannot be recommended concerning these ACPA.

- Among at-risk patients, we found a prognostic value for baseline circulating SC ACPA regarding progression to arthritis. This implies that serum SC ACPA analysis could be beneficial as part of routine clinical care. For instance, adding serum SC ACPA analysis in IgG ACPA positive arthralgia cases could be used to refine the prognostics regarding risk of progression to arthritis. This could potentially improve referral procedures from primary care to rheumatology departments, identifying those with particular risk of progression. However, our finding needs to be replicated in larger patient cohorts, and to make it clinically useful we need to determine risk estimates within different SC ACPA level categories. 


\section{Conclusions}

The presence of secretory ACPA in the circulation and in two different mucosal secretions from patients with RA and at-risk patients is demonstrated (Figure 11). The presence of secretory ACPA, and the associations with several clinical features, are indicative of a connection between the mucosa and the pathogenesis of ACPA positive RA.

- Circulating SC ACPA are present in a subpopulation of early and established RA patients and in an at-risk population, and associates with smoking and inflammatory activity.

- In treatment-naïve early RA patients, SC ACPA are detected in the BALF and circulating SC ACPA are associated with lung abnormalities detected by HRCT, supporting a linkage between mucosal ACPA responses and the lungs in ACPA positive RA.

- Salivary IgA ACPA occur in a subpopulation of RA patients and are associated with higher disease activity and functional disability. Mucosal ACPA responses in the oral cavity to citrullinated proteins may be of importance in RA.

- Baseline SC ACPA levels are prognostic for arthritis development in IgG ACPA positive at-risk patients and strengthen the idea of a mucosal link in RA development. 


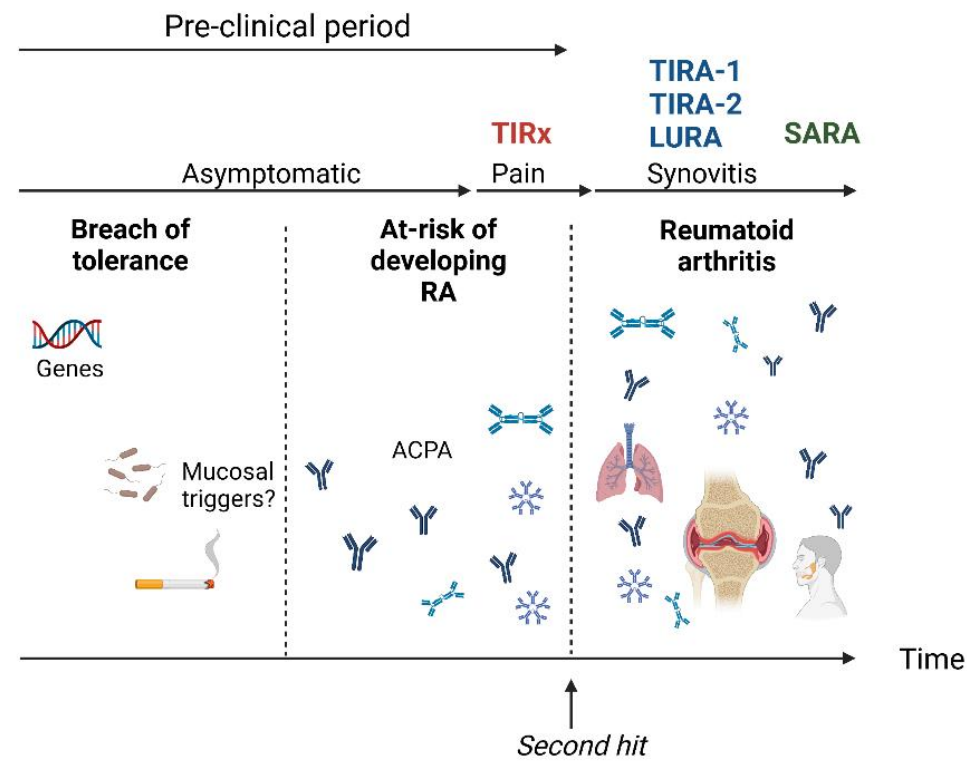

Figure 11 In this thesis, secretory component containing (SC) anti-citrullinated protein antibodies (ACPA) have been demonstrated in at-risk individuals (TIRx), in early rheumatoid arthritis (RA) patients (TIRA-1, TIRA-2 and LURA) and established patients with RA (SARA). In LURA, signs of lung involvement were shown and in SARA, salivary IgA ACPA was confirmed and associated to disease activity. 


\section{Future perspectives}

Future studies should investigate further SC ACPA and its part in the pathogenesis of ACPA positive RA. The ultimate goal for preclinical research on RA and its association with the mucosal immune system is to discover key mechanisms underlying the pathogenesis of the disease, so as to derive targets for preventive treatment (mostly likely in at-risk persons with a known higher risk of developing RA).

Interventions that could be made already in the at-risk phases of the disease could include mucosal immune regulation (e.g., dental hygiene interventions or diet changes) and therapies that are directly delivered to mucosal sites to induce oral tolerance (159). In murine models, treatment with a PAD inhibitor (CI-amidine) has been shown to reduce arthritis severity and decreased serum interleukin (IL)-6 levels, although no change in ACPA levels was reported $(160,161)$. This could be a future therapeutic target for RA treatment or in at-risk persons since PADs are necessary for citrullination. Changes to the diet, e.g., higher fiber intake, which result in modification of the microbiota in the gastrointestinal system and alterations to the local immune system (with a reported increase in circulating $\mathrm{T}$ regulatory cells (130)) could promote the anti-inflammatory activities of the mucosal immune system in at-risk patients. Interventions that optimize the oral hygiene of at-risk patients so as to minimize the bacterial load in the oral cavity might reduce the local levels of citrullination (produced by $P$. gingivalis). This could reduce the formation of neoantigens and decrease the risk of developing RA. In studies of patients with RA and at-risk persons, there were no differences in the results from the periodontal examinations (127). However, in longitudinal studies, dental hygiene interventions may prove to be of importance.

While the appropriate population in which to perform screening for $\mathrm{RA}$ is a matter of debate, screening the general population for IgG ACPA is unlikely to be the best strategy. In a large general population cohort in Sweden, $2 \%$ of the participants tested positive for ACPA, and during the follow-up 21 out of 247 developed RA within 3 years (162). Screening might instead be performed in populations that have a known higher baseline risk of developing RA, e.g., individuals with a family history of RA or other autoimmune diseases, those who are exposed to certain environmental risk factors or members of ethnic groups that have a higher prevalence of RA $(23,163,164)$. A decline in ovarian function in postmenopausal women who have an FDR with RA has been linked to ACPA positivity, and this could be a population at risk for RA (165). As SC ACPA is rarely detected in IgG ACPA negative patients, it is not useful to test for only this ACPA isotype. However, if replicating studies confirm that 
SC ACPA predicts arthritis development, SC ACPA could be a candidate for testing in IgG ACPA positive patients (perhaps performed automatically in the laboratory testing procedure), to differentiate persons who have a higher risk of developing RA. In our study, we included only symptomatic persons, and in the clinical routine, ACPA testing is mainly performed for patients who have any kind of musculoskeletal pain or arthralgia. It would be interesting in future studies to test for SC ACPA in other at-risk populations (e.g., patients with other autoimmune diseases), to see if SC ACPA is present and can predict arthritis development, given that SC ACPA has been shown to be very uncommon in FDRs (138).

It would be of interest to investigate the following aspects of SC ACPA in patients with RA and at-risk individuals:

- Investigation of larger populations of at-risk individuals and the prognostic value of SC ACPA. The ultimate goal would be to identify patients in primary care centers who would benefit from preventive treatment.

- Longitudinal studies of at-risk individuals, including both serum samples and mucosal secretions, to establish the respective proportions of components of mucosal secretions to the levels of circulating SC ACPA.

- Clarification of the prognostic value of IgA ACPA in saliva in longitudinal studies, involving both at-risk individuals and newly diagnosed patients with RA.

- Investigation of the potential connection between oral pathogens and RA, as these pathogens are possible inducers of mucosal immune reactions and potential triggers for IgA ACPA production locally in the saliva.

- Analyses of the local mucosal secretions in the gastrointestinal tract for SC ACPA, both in early RA patients and at-risk populations. 


\section{Acknowledgements}

Att under denna tid fått vara del av en fantastisk forskargrupp och även omringats av otroliga forskarkollegor på CKF, har gjort dessa år till en mycket lärorik resa.

Först och främst vill jag tacka min huvudhandledare Alf Kastbom, utan dig hade jag nog aldrig ens tänkt tanken att jag skulle fortsätta med doktorandstudier och ditt brinnande intresse och engagemang är en sann inspirationskälla. Att du alltid funnits där för frågor och stöttning, när som helst, under arbetes gång har gjort detta arbete lite lättare. Du har under åren som gått fått mig att utvecklas och bli mera självständig, tack för det!

Mina underbara bihandledare; Anna Svärd du tog dig an mig som student och visade att det gick att kombinera forskarvärlden med kliniskt arbete. Det var du som fick mig att tycka att forskning och labbande var roligt och har under tiden blivit en vän och trygghet på CKF som alltid tagit dig tid om det varit något. Klara Martinsson, ditt strålande humör och positivitet är inspirerande och att jag alltid har kunnat fråga dig om laborationsmetoder med mera har varit uppskattat. Jonas Wetterö, jag vet väldigt få personer som sprider sådan glädje. Tack för att du alltid funnits där med snabba svar på diverse frågor.

Jag vill också tacka Region Dalarna och mina chefer som gjort det möjligt för mig att genomföra detta arbete. Föreståndare Erica Schytt på CKF i Dalarna, tack för ditt genuina intresse både för forskning och andra icke-forskningsanknutna diskussionsämnen vid fikabordet på CKF. Eva Lööf som gav mig möjligheten att börja doktorandstudierna under tiden för AT-tjänstgöringen och att du aldrig sett att något är omöjligt. Karin Florén för att jag fătt tiden till att fortsätta att forska.

Jag vill också tacka kansliet på CKF, för att ni alltid ger snabba svar på frågor rörande det mesta och tack till forskarkollegorna på CKF för intressanta diskussioner både under seminarier och matstunder. Mina genuina tackhälsningar går också till laboratoriepersonalen på serologisektionen vid mikrobiologen på Falu Lasarett som gjort det möjligt för mig och gett mig en plats vid er arbetsbänk att genomföra stora delar av mina laborativa delar i detta arbete hos er. Det har varit värt mycket för mig och ni har alltid tagit er tid att svara på frågor.

Tack kära kollegor på Gagnefs Vårdcentral som hjälpt till med att ta hand om mina patienter och provsvar när jag inte varit på plats och speciellt tack till mina handledare. Tidigare handledare Karin Lisspers för ditt stora intresse för min forskning och forskning i stort och min nuvarande handledare Ulf Börjesson för att du är en äldre kollega att se upp till och att du alltid finns där vid frågor, stort som smått. 
Ett stort tack också till alla patienter som deltagit i dessa studier, utan er hade arbetet inte kunnat genomföras. Jag önskar också tacka mina medförfattare Michael Ziegelasch, Yngve Sommarin, Thomas Skogh, Vijay Joshua, Anders Eklund, Magnus Sköld, Reza Karimi, Sven Nyrén, Anca Catrina och Emil Börjesson, för gott samarbete!

Till sist, tack till min älskade familj, utan er hade jag inte varit någonting! Mamma Sonja och pappa Sören, tack för att ni alltid stöttat mig och trott på mig att jag ska klara av vad jag än har gett mig in på här i livet. Utan er hade livspusslet inte gått ihop med familj, gård och arbete. Syster Stina för att du alltid finns där. Mina svärföräldrar, Agneta och Börje, tack för stöttning och för visat intresse för mitt forskningsarbete och hjälp med barnpassning. Och så de personer som betyder allra mest för mig; älskade Daniel tack att du alltid finns vid min sida, i ur och skur, och att du är det tryggaste i mitt liv. Utan dina uppmuntrande och stöttande ord hade det här arbetet inte varit möjligt! Tack att du tagit hand om allt när jag behövt vara borta i perioder i och med studierna. Mina små älsklingar, Axel och Anders, tack för att ni ger så mycket energi och glädje i livet. Älskar er alla tre! 


\section{References}

1. Silman AJ, Pearson JE. Epidemiology and genetics of rheumatoid arthritis. Arthritis Res. 2002;4 Suppl 3(Suppl 3):S265-72.

2. Kvien TK, Uhlig T, Ødegård S, Heiberg MS. Epidemiological aspects of rheumatoid arthritis: the sex ratio. Ann N Y Acad Sci. 2006;1069:212-22.

3. Smolen JS, Aletaha D, McInnes IB. Rheumatoid arthritis. Lancet. 2016;388(10055):2023-38.

4. Aletaha D, Smolen JS. Diagnosis and Management of Rheumatoid Arthritis: A Review. JAMA. 2018;320(13):1360-72.

5. Arnett FC, Edworthy SM, Bloch DA, McShane DJ, Fries JF, Cooper NS, et al. The American Rheumatism Association 1987 revised criteria for the classification of rheumatoid arthritis. Arthritis Rheum. 1988;31(3):315-24.

$6 . \quad$ Aletaha D, Neogi T, Silman AJ, Funovits J, Felson DT, Bingham CO, 3rd, et al. 2010 Rheumatoid arthritis classification criteria: an American College of Rheumatology/European League Against Rheumatism collaborative initiative. Arthritis Rheum. 2010;62(9):256981.

7.

Rönnelid J, Turesson C, Kastbom A. Autoantibodies in Rheumatoid Arthritis - Laboratory and Clinical Perspectives. Front Immunol. 2021;12:685312.

8. Waaler E. On the occurrence of a factor in human serum activating the specific agglutintion of sheep blood corpuscles. 1939. APMIS. 2007;115(5):422-38; discussion 39.

9.

Aggarwal R, Liao K, Nair R, Ringold S, Costenbader KH. Anti-citrullinated peptide antibody assays and their role in the diagnosis of rheumatoid arthritis. Arthritis Rheum. 2009;61(11):1472-83.

10. Bas S, Perneger TV, Kunzle E, Vischer TL. Comparative study of different enzyme immunoassays for measurement of IgM and IgA rheumatoid factors. Ann Rheum Dis. 2002;61(6):505-10.

11.

Gioud-Paquet M, Auvinet M, Raffin T, Girard P, Bouvier M, Lejeune E, et al. IgM rheumatoid factor (RF), IgA RF, IgE RF, and IgG RF detected by ELISA in rheumatoid arthritis. Ann Rheum Dis. 1987;46(1):65-71.

12. Schellekens GA, de Jong BA, van den Hoogen FH, van de Putte LB, van Venrooij WJ. Citrulline is an essential constituent of antigenic determinants recognized by rheumatoid arthritis-specific autoantibodies. The Journal of clinical investigation. 1998;101(1):27381. 
13.

van Venrooij WJ, van Beers JJ, Pruijn GJ. Anti-CCP Antibody, a Marker for the Early Detection of Rheumatoid Arthritis. Ann N Y Acad Sci. 2008;1143:268-85.

14. Witalison EE, Thompson PR, Hofseth LJ. Protein Arginine Deiminases and Associated Citrullination: Physiological Functions and Diseases Associated with Dysregulation. Curr Drug Targets. 2015;16(7):700-10.

15. Valesini G, Gerardi MC, Iannuccelli C, Pacucci VA, Pendolino M, Shoenfeld Y. Citrullination and autoimmunity. Autoimmun Rev. 2015;14(6):490-7.

16. Nienhuis RL, Mandema E. A new serum factor in patients with rheumatoid arthritis; the antiperinuclear factor. Ann Rheum Dis. 1964;23(4):302-5.

17. Young BJ, Mallya RK, Leslie RD, Clark CJ, Hamblin TJ. Anti-keratin antibodies in rheumatoid arthritis. $\mathrm{Br}$ Med $\mathrm{J}$. 1979;2(6182):97-9.

18. Sebbag M, Simon M, Vincent C, Masson-Bessière C, Girbal E, Durieux JJ, et al. The antiperinuclear factor and the so-called antikeratin antibodies are the same rheumatoid arthritis-specific autoantibodies. J Clin Invest. 1995;95(6):2672-9.

19.

Payet J, Goulvestre C, Bialé L, Avouac J, Wipff J, JobDeslandre $\mathrm{C}$, et al. Anticyclic citrullinated peptide antibodies in rheumatoid and nonrheumatoid rheumatic disorders: experience with 1162 patients. J Rheumatol. 2014;41(12):2395-402.

20. Coenen D, Verschueren P, Westhovens R, Bossuyt X. Technical and diagnostic performance of 6 assays for the measurement of citrullinated protein/peptide antibodies in the diagnosis of rheumatoid arthritis. Clin Chem. 2007;53(3):498-504.

21. Ziegelasch M, van Delft MA, Wallin P, Skogh T, MagroCheca C, Steup-Beekman GM, et al. Antibodies against carbamylated proteins and cyclic citrullinated peptides in systemic lupus erythematosus: results from two well-defined European cohorts. Arthritis Res Ther. 2016;18(1):289.

22.

Schellekens GA, Visser H, de Jong BA, van den Hoogen FH, Hazes JM, Breedveld FC, et al. The diagnostic properties of rheumatoid arthritis antibodies recognizing a cyclic citrullinated peptide. Arthritis Rheum. 2000;43(1):155-63.

23. Finckh A, Courvoisier D, Lamacchia C. Measuring ACPA in the general population or primary care: is it useful? RMD Open. 2020;6(1):e001085.

24. van Gaalen FA, Visser H, Huizinga TW. A comparison of the diagnostic accuracy and prognostic value of the first and second anti- 
cyclic citrullinated peptides ( $\mathrm{CCP} 1$ and $\mathrm{CCP} 2)$ autoantibody tests for rheumatoid arthritis. Ann Rheum Dis. 2005;64(10):1510-2.

25. Santiago M, Baron M, Miyachi K, Fritzler MJ, Abu-Hakima $\mathrm{M}$, Leclercq S, et al. A comparison of the frequency of antibodies to cyclic citrullinated peptides using a third generation anti-CCP assay $\left(\mathrm{CCP}_{3}\right)$ in systemic sclerosis, primary biliary cirrhosis and rheumatoid arthritis. Clin Rheumatol. 2008;27(1):77-83.

26. Demoruelle MK, Parish MC, Derber LA, Kolfenbach JR, Hughes-Austin JM, Weisman MH, et al. Performance of anti-cyclic citrullinated Peptide assays differs in subjects at increased risk of rheumatoid arthritis and subjects with established disease. Arthritis Rheum. 2013;65(9):2243-52.

27. Trouw LA, Mahler M. Closing the serological gap: promising novel biomarkers for the early diagnosis of rheumatoid arthritis. Autoimmun Rev. 2012;12(2):318-22.

28. Nishimura K, Sugiyama D, Kogata Y, Tsuji G, Nakazawa T, Kawano S, et al. Meta-analysis: diagnostic accuracy of anti-cyclic citrullinated peptide antibody and rheumatoid factor for rheumatoid arthritis. Ann Intern Med. 2007;146(11):797-808.

29. van Venrooij WJ, van Beers JJ, Pruijn GJ. Anti-CCP antibodies: the past, the present and the future. Nat Rev Rheumatol. 2011;7(7):391-8.

30. Kastbom A, Strandberg G, Lindroos A, Skogh T. Anti-CCP antibody test predicts the disease course during 3 years in early rheumatoid arthritis (the Swedish TIRA project). Ann Rheum Dis. 2004;63(9):1085-9.

31. van der Woude D, Syversen SW, van der Voort EI, Verpoort KN, Goll GL, van der Linden MP, et al. The ACPA isotype profile reflects long-term radiographic progression in rheumatoid arthritis. Ann Rheum Dis. 2010;69(6):1110-6.

32. Lakos G, Soos L, Fekete A, Szabo Z, Zeher M, Horvath IF, et al. Anti-cyclic citrullinated peptide antibody isotypes in rheumatoid arthritis: association with disease duration, rheumatoid factor production and the presence of shared epitope. Clin Exp Rheumatol. 2008;26(2):253-60.

33. Svärd A, Kastbom A, Reckner-Olsson A, Skogh T. Presence and utility of IgA-class antibodies to cyclic citrullinated peptides in early rheumatoid arthritis: the Swedish TIRA project. Arthritis Res Ther. 2008;10(4):R75.

34. Svärd A, Skogh T, Alfredsson L, Ilar A, Klareskog L, Bengtsson C, et al. Associations with smoking and shared epitope differ between IgA- and IgG-class antibodies to cyclic citrullinated peptides in early rheumatoid arthritis. Artritis Rheumatol. 2015;67(8):2032-7. 
35.

Snir O, Widhe M, Hermansson M, von Spee C, Lindberg J, Hensen S, et al. Antibodies to several citrullinated antigens are enriched in the joints of rheumatoid arthritis patients. Arthritis Rheum. 2010;62(1):44-52.

36. Nielen MM, van Schaardenburg D, Reesink HW, van de Stadt RJ, van der Horst-Bruinsma IE, de Koning MH, et al. Specific autoantibodies precede the symptoms of rheumatoid arthritis: a study of serial measurements in blood donors. Arthritis Rheum. 2004;50(2):380-6.

37. Rantapää-Dahlqvist S, de Jong BA, Berglin E, Hallmans G, Wadell $\mathrm{G}$, Stenlund $\mathrm{H}$, et al. Antibodies against cyclic citrullinated peptide and IgA rheumatoid factor predict the development of rheumatoid arthritis. Arthritis Rheum. 2003;48(10):2741-9.

38. Berglin E, Johansson T, Sundin U, Jidell E, Wadell G, Hallmans G, et al. Radiological outcome in rheumatoid arthritis is predicted by presence of antibodies against cyclic citrullinated peptide before and at disease onset, and by IgA-RF at disease onset. Ann Rheum Dis. 2006;65(4):453-8.

39. Rönnelid J, Wick MC, Lampa J, Lindblad S, Nordmark B, Klareskog L, et al. Longitudinal analysis of citrullinated protein/peptide antibodies (anti-CP) during 5 year follow up in early rheumatoid arthritis: anti-CP status predicts worse disease activity and greater radiological progression. Ann Rheum Dis. 2005;64(12):1744-9.

40. Sokolove J, Zhao X, Chandra PE, Robinson WH. Immune complexes containing citrullinated fibrinogen costimulate macrophages via Toll-like receptor 4 and $\mathrm{Fc} \gamma$ receptor. Arthritis Rheum. 2011;63(1):53-62.

41. Trouw LA, Haisma EM, Levarht EW, van der Woude D, Ioan-Facsinay A, Daha MR, et al. Anti-cyclic citrullinated peptide antibodies from rheumatoid arthritis patients activate complement via both the classical and alternative pathways. Arthritis Rheum. 2009;60(7):1923-31.

42. Luan J, Hu Z, Cheng J, Zhang R, Yang P, Guo H, et al. Applicability and implementation of the collagen-induced arthritis mouse model, including protocols (Review). Exp Ther Med. 2021;22(3):939.

43. Kuhn KA, Kulik L, Tomooka B, Braschler KJ, Arend WP, Robinson $\mathrm{WH}$, et al. Antibodies against citrullinated proteins enhance tissue injury in experimental autoimmune arthritis. J Clin Invest. 2006;116(4):961-73.

44. Kwon EJ, Ju JH. Impact of Posttranslational Modification in Pathogenesis of Rheumatoid Arthritis: Focusing on Citrullination, Carbamylation, and Acetylation. Int J Mol Sci. 2021;22(19):10576. 
45.

Shi J, Knevel R, Suwannalai P, van der Linden MP, Janssen GM, van Veelen PA, et al. Autoantibodies recognizing carbamylated proteins are present in sera of patients with rheumatoid arthritis and predict joint damage. Proc Natl Acad Sci U S A. 2011;108(42):17372-7.

46. Brink M, Verheul MK, Rönnelid J, Berglin E, Holmdahl R, Toes RE, et al. Anti-carbamylated protein antibodies in the presymptomatic phase of rheumatoid arthritis, their relationship with multiple anti-citrulline peptide antibodies and association with radiological damage. Arthritis Res Ther. 2015;17(1):25.

47. Grönwall C, Liljefors L, Bang H, Hensvold AH, Hansson M, Mathsson-Alm L, et al. A Comprehensive Evaluation of the Relationship Between Different IgG and IgA Anti-Modified Protein Autoantibodies in Rheumatoid Arthritis. Front Immunol. 2021;12:627986.

48. Kronzer VL, Davis JM, 3rd. Etiologies of Rheumatoid Arthritis: Update on Mucosal, Genetic, and Cellular Pathogenesis. Curr Rheumatol Rep. 2021;23(4):21.

49. Salliot C, Nguyen Y, Boutron-Ruault MC, Seror R. Environment and Lifestyle: Their Influence on the Risk of RA. J Clin Med. 2020;9(10):3109.

50. Thomas DJ, Young A, Gorsuch AN, Bottazzo GF, Cudworth AG. Evidence for an association between rheumatoid arthritis and autoimmune endocrine disease. Ann Rheum Dis. 1983;42(3):297-300.

51. Frisell T, Saevarsdottir S, Askling J. Family history of rheumatoid arthritis: an old concept with new developments. Nat Rev Rheumatol. 2016;12(6):335-43.

52. Frisell T, Holmqvist M, Källberg H, Klareskog L, Alfredsson L, Askling J. Familial risks and heritability of rheumatoid arthritis: role of rheumatoid factor/anti-citrullinated protein antibody status, number and type of affected relatives, sex, and age. Arthritis Rheum. 2013;65(11):2773-82.

53. Svendsen AJ, Kyvik KO, Houen G, Junker P, Christensen $\mathrm{K}$, Christiansen L, et al. On the origin of rheumatoid arthritis: the impact of environment and genes--a population based twin study. PLoS One. 2013;8(2):e57304.

54. Holoshitz J. The rheumatoid arthritis HLA-DRB1 shared epitope. Curr Opin Rheumatol. 2010;22(3):293-8.

55. Jiang X, Alfredsson L. Modifiable environmental exposure and risk of rheumatoid arthritis-current evidence from genetic studies. Arthritis Res Ther. 2020;22(1):154.

56. Di Giuseppe D, Discacciati A, Orsini N, Wolk A. Cigarette smoking and risk of rheumatoid arthritis: a dose-response metaanalysis. Arthritis Res Ther. 2014;16(2):R61. 
57 .

Hedström AK, Stawiarz L, Klareskog L, Alfredsson L. Smoking and susceptibility to rheumatoid arthritis in a Swedish population-based case-control study. Eur J Epidemiol. 2018;33(4):41523.

58.

Klareskog L, Stolt P, Lundberg K, Källberg H, Bengtsson C, Grunewald J, et al. A new model for an etiology of rheumatoid arthritis: smoking may trigger HLA-DR (shared epitope)-restricted immune reactions to autoantigens modified by citrullination. Arthritis Rheum. 2006;54(1):38-46.

59. Källberg H, Ding B, Padyukov L, Bengtsson C, Rönnelid J, Klareskog L, et al. Smoking is a major preventable risk factor for rheumatoid arthritis: estimations of risks after various exposures to cigarette smoke. Ann Rheum Dis. 2011;70(3):508-11.

60. de Hair MJ, van de Sande MG, Ramwadhdoebe TH, Hansson M, Landewé R, van der Leij C, et al. Features of the synovium of individuals at risk of developing rheumatoid arthritis: implications for understanding preclinical rheumatoid arthritis. Artritis Rheumatol. 2014;66(3):513-22.

61. van de Sande MG, de Hair MJ, van der Leij C, Klarenbeek PL, Bos WH, Smith MD, et al. Different stages of rheumatoid arthritis: features of the synovium in the preclinical phase. Ann Rheum Dis. 2011;70(5):772-7.

62. Gerlag DM, Raza K, van Baarsen LG, Brouwer E, Buckley $\mathrm{CD}$, Burmester GR, et al. EULAR recommendations for terminology and research in individuals at risk of rheumatoid arthritis: report from the Study Group for Risk Factors for Rheumatoid Arthritis. Ann Rheum Dis. 2012;71(5):638-41.

63. Holers VM, Demoruelle MK, Kuhn KA, Buckner JH, Robinson WH, Okamoto Y, et al. Rheumatoid arthritis and the mucosal origins hypothesis: protection turns to destruction. Nat Rev Rheumatol. 2018;14(9):542-57.

64. Bos WH, Wolbink GJ, Boers M, Tijhuis GJ, de Vries N, van der Horst-Bruinsma IE, et al. Arthritis development in patients with arthralgia is strongly associated with anti-citrullinated protein antibody status: a prospective cohort study. Ann Rheum Dis. 2010;69(3):490-4.

65. Molendijk M, Hazes JM, Lubberts E. From patients with arthralgia, pre-RA and recently diagnosed RA: what is the current status of understanding RA pathogenesis? RMD Open. 2018;4(1):eooo256.

66. Deane KD. Preclinical Rheumatoid Arthritis and Rheumatoid Arthritis Prevention. Curr Rheumatol Rep. 2018;20(8):50. 67. Catrina A, Krishnamurthy A, Rethi B. Current view on the pathogenic role of anti-citrullinated protein antibodies in rheumatoid arthritis. RMD Open. 2021;7(1):e001228. 
68.

Deane KD, O'Donnell CI, Hueber W, Majka DS, Lazar AA, Derber LA, et al. The number of elevated cytokines and chemokines in preclinical seropositive rheumatoid arthritis predicts time to diagnosis in an age-dependent manner. Arthritis Rheum. 2010;62(11):3161-72.

69.

Kokkonen H, Söderström I, Rocklöv J, Hallmans G, Lejon K, Rantapää Dahlqvist S. Up-regulation of cytokines and chemokines predates the onset of rheumatoid arthritis. Arthritis Rheum. 2010;62(2):383-91.

70. $\quad$ Miyabe Y, Lian J, Miyabe C, Luster AD. Chemokines in rheumatic diseases: pathogenic role and therapeutic implications. Nat Rev Rheumatol. 2019;15(12):731-46.

71. Sokolove J, Bromberg R, Deane KD, Lahey LJ, Derber LA, Chandra PE, et al. Autoantibody epitope spreading in the pre-clinical phase predicts progression to rheumatoid arthritis. PLoS One. 2012;7(5):e35296.

72. $\quad$ Falkenburg WJJ, van Schaardenburg D. Evolution of autoantibody responses in individuals at risk of rheumatoid arthritis. Best Pract Res Clin Rheumatol. 2017;31(1):42-52.

73. Nam JL, Hunt L, Hensor EM, Emery P. Enriching case selection for imminent RA: the use of anti-CCP antibodies in individuals with new non-specific musculoskeletal symptoms - a cohort study. Ann Rheum Dis. 2016;75(8):1452-6.

74. Rakieh C, Nam JL, Hunt L, Hensor EM, Das S, Bissell LA, et al. Predicting the development of clinical arthritis in anti-CCP positive individuals with non-specific musculoskeletal symptoms: a prospective observational cohort study. Ann Rheum Dis. 2015;74(9):1659-66.

75. van de Stadt LA, Witte BI, Bos WH, van Schaardenburg D. A prediction rule for the development of arthritis in seropositive arthralgia patients. Ann Rheum Dis. 2013;72(12):1920-6.

76. Ten Brinck RM, van Steenbergen HW, van Delft MAM, Verheul MK, Toes REM, Trouw LA, et al. The risk of individual autoantibodies, autoantibody combinations and levels for arthritis development in clinically suspect arthralgia. Rheumatology (Oxford). 2017;56(12):2145-53.

77. $\quad$ Eloff E, Martinsson K, Ziegelasch M, Cedergren J, Reckner $\AA$, Skogh T, et al. Autoantibodies are major predictors of arthritis development in patients with anti-citrullinated protein antibodies and musculoskeletal pain. Scand J Rheumatol. 2021;50(3):189-97.

78. Brandtzaeg P. Mucosal immunity: induction, dissemination, and effector functions. Scand $\mathrm{J}$ Immunol. 2009;70(6):505-15.

79. Weiner HL, da Cunha AP, Quintana F, Wu H. Oral tolerance. Immunol Rev. 2011;241(1):241-59. 
80. Cesta MF. Normal structure, function, and histology of mucosa-associated lymphoid tissue. Toxicol Pathol. 2006;34(5):599608.

81. Brandtzaeg P. Two types of IgA immunocytes in man. Nat New Biol. 1973;243(126):142-3.

82. Woof JM, Russell MW. Structure and function relationships in IgA. Mucosal Immunol. 2011;4(6):590-7.

83. Brandtzaeg P. Human secretory immunoglobulin M. An immunochemical and immunohistochemical study. Immunology. 1975;29(3):559-70.

84. Corthésy B. Multi-faceted functions of secretory IgA at mucosal surfaces. Front Immunol. 2013;4:185.

85. Leong KW, Ding JL. The unexplored roles of human serum IgA. DNA Cell Biol. 2014;33(12):823-9.

86. Waldman RH, Mach JP, Stella MM, Rowe DS. Secretory IgA in human serum. J Immunol. 1970;105(1):43-7.

87. Eijgenraam JW, Oortwijn BD, Kamerling SWA, De Fijter JW, Van Den Wall Bake AWL, Daha MR, et al. Secretory immunoglobulin A (IgA) responses in IgA nephropathy patients after mucosal immunization, as part of a polymeric IgA response. Clin Exp Immunol. 2008;152(2):227-32.

88. Delacroix D, Dive C, Rambaud JC, Vaerman JP. IgA subclasses in various secretions and in serum. Immunology. 1982;47(2):383-5.

89. Pakkanen SH, Kantele JM, Moldoveanu Z, Hedges S, Hakkinen M, Mestecky J, et al. Expression of homing receptors on IgA1 and IgA2 plasmablasts in blood reflects differential distribution of IgA1 and IgA2 in various body fluids. Clin Vaccine Immunol. 2010;17(3):393401.

90. Jorgensen C, Moynier M, Bologna C, Youinou P, Sany J. Rheumatoid factor associated with a secretory component in rheumatoid arthritis. Br J Rheumatol. 1995;34(3):236-40.

91. Otten HG, Daha MR, van Laar JM, de Rooy HH, Breedveld FC. Subclass distribution and size of human IgA rheumatoid factor at mucosal and nonmucosal sites. Arthritis Rheum. 1991;34(7):831-9.

92. Zaiss MM, Joyce Wu HJ, Mauro D, Schett G, Ciccia F. The gut-joint axis in rheumatoid arthritis. Nat Rev Rheumatol. 2021;17(4):224-37.

93. Catrina AI, Deane KD, Scher JU. Gene, environment, microbiome and mucosal immune tolerance in rheumatoid arthritis. Rheumatology (Oxford). 2016;55(3):391-402. 
94. Scher JU, Joshua V, Artacho A, Abdollahi-Roodsaz S, Ockinger J, Kullberg S, et al. The lung microbiota in early rheumatoid arthritis and autoimmunity. Microbiome. 2016;4(1):60.

95. Kroese JM, Brandt BW, Buijs MJ, Crielaard W, Lobbezoo F, Loos BG, et al. Differences in the Oral Microbiome in Patients With Early Rheumatoid Arthritis and Individuals at Risk of Rheumatoid Arthritis Compared to Healthy Individuals. Artritis Rheumatol. 2021;73(11):1986-93.

96. $\quad$ Scher JU, Ubeda C, Equinda M, Khanin R, Buischi Y, Viale $\mathrm{A}$, et al. Periodontal disease and the oral microbiota in new-onset rheumatoid arthritis. Arthritis Rheum. 2012;64(10):3083-94.

97. Cheng Z, Do T, Mankia K, Meade J, Hunt L, Clerehugh V, et al. Dysbiosis in the oral microbiomes of anti-CCP positive individuals at risk of developing rheumatoid arthritis. Ann Rheum Dis. 2021;80(2):162-8.

98. Scher JU, Sczesnak A, Longman RS, Segata N, Ubeda C, Bielski C, et al. Expansion of intestinal Prevotella copri correlates with enhanced susceptibility to arthritis. Elife. 2013;2:e01202.

99. Radbruch A, Muehlinghaus G, Luger EO, Inamine A, Smith KG, Dörner T, et al. Competence and competition: the challenge of becoming a long-lived plasma cell. Nat Rev Immunol. 2006;6(10):74150.

100. Kinslow JD, Blum LK, Deane KD, Demoruelle MK, Okamoto Y, Parish MC, et al. Elevated IgA Plasmablast Levels in Subjects at Risk of Developing Rheumatoid Arthritis. Artritis Rheumatol. 2016;68(10):2372-83.

101. Reynisdottir G, Karimi R, Joshua V, Olsen H, Hensvold $\mathrm{AH}$, Harju A, et al. Structural changes and antibody enrichment in the lungs are early features of anti-citrullinated protein antibody-positive rheumatoid arthritis. Artritis Rheumatol. 2014;66(1):31-9.

102. Svärd A, Kastbom A, Sommarin Y, Skogh T. Salivary IgA antibodies to cyclic citrullinated peptides (CCP) in rheumatoid arthritis. Immunobiology. 2013;218(2):232-7.

103. Willis VC, Demoruelle MK, Derber LA, Chartier-Logan CJ, Parish MC, Pedraza IF, et al. Sputum autoantibodies in patients with established rheumatoid arthritis and subjects at risk of future clinically apparent disease. Arthritis Rheum. 2013;65(10):2545-54.

104. Stolt P, Yahya A, Bengtsson C, Källberg H, Rönnelid J, Lundberg I, et al. Silica exposure among male current smokers is associated with a high risk of developing ACPA-positive rheumatoid arthritis. Ann Rheum Dis. 2010;69(6):1072-6. 
105. Catrina AI, Ytterberg AJ, Reynisdottir G, Malmström V, Klareskog L. Lungs, joints and immunity against citrullinated proteins in rheumatoid arthritis. Nat Rev Rheumatol. 2014;10(11):645-53.

106. Sparks JA, Karlson EW. The Roles of Cigarette Smoking and the Lung in the Transitions Between Phases of Preclinical Rheumatoid Arthritis. Curr Rheumatol Rep. 2016;18(3):15.

107. Rangel-Moreno J, Hartson L, Navarro C, Gaxiola M, Selman M, Randall TD. Inducible bronchus-associated lymphoid tissue (iBALT) in patients with pulmonary complications of rheumatoid arthritis. J Clin Invest. 2006;116(12):3183-94.

108. Demoruelle MK, Weisman MH, Simonian PL, Lynch DA, Sachs PB, Pedraza IF, et al. Brief report: airways abnormalities and rheumatoid arthritis-related autoantibodies in subjects without arthritis: early injury or initiating site of autoimmunity? Arthritis Rheum. 2012;64(6):1756-61.

109. Demoruelle MK, Harrall KK, Ho L, Purmalek MM, Seto NL, Rothfuss HM, et al. Anti-Citrullinated Protein Antibodies Are Associated With Neutrophil Extracellular Traps in the Sputum in Relatives of Rheumatoid Arthritis Patients. Artritis Rheumatol. 2017;69(6):1165-75. 110. Ruiz-Esquide V, Gomara MJ, Peinado VI, Gomez Puerta JA, Barbera JA, Canete Jde D, et al. Anti-citrullinated peptide antibodies in the serum of heavy smokers without rheumatoid arthritis. A differential effect of chronic obstructive pulmonary disease? Clin Rheumatol. 2012;31(7):1047-50.

111. Reynisdottir G, Olsen H, Joshua V, Engström M, Forsslund $\mathrm{H}$, Karimi R, et al. Signs of immune activation and local inflammation are present in the bronchial tissue of patients with untreated early rheumatoid arthritis. Ann Rheum Dis. 2016;75(9):1722-7.

112. Ytterberg AJ, Joshua V, Reynisdottir G, Tarasova NK, Rutishauser D, Ossipova E, et al. Shared immunological targets in the lungs and joints of patients with rheumatoid arthritis: identification and validation. Ann Rheum Dis. 2015;74(9):1772-7.

113. Vihlborg P, Bryngelsson IL, Andersson L, Graff P. Risk of sarcoidosis and seropositive rheumatoid arthritis from occupational silica exposure in Swedish iron foundries: a retrospective cohort study. BMJ Open. 2017;7(7):e016839.

114. Rutger Persson G. Rheumatoid arthritis and periodontitis - inflammatory and infectious connections. Review of the literature. J Oral Microbiol. 2012;4:11829.

115. de Smit M, Westra J, Vissink A, Doornbos-van der Meer B, Brouwer E, van Winkelhoff AJ. Periodontitis in established rheumatoid arthritis patients: a cross-sectional clinical, microbiological and serological study. Arthritis Res Ther. 2012;14(5):R222. 
116. Eriksson K, Nise L, Kats A, Luttropp E, Catrina AI, Askling $\mathrm{J}$, et al. Prevalence of Periodontitis in Patients with Established Rheumatoid Arthritis: A Swedish Population Based Case-Control Study. PLoS One. 2016;11(5):e0155956.

117. de Smit MJ, Brouwer E, Vissink A, van Winkelhoff AJ. Rheumatoid arthritis and periodontitis; a possible link via citrullination. Anaerobe. 2011;17(4):196-200.

118. Qiao Y, Wang Z, Li Y, Han Y, Zhou Y, Cao X. Rheumatoid arthritis risk in periodontitis patients: A systematic review and metaanalysis. Joint Bone Spine. 2020;87(6):556-64.

119. Demmer RT, Molitor JA, Jacobs DR, Jr., Michalowicz BS. Periodontal disease, tooth loss and incident rheumatoid arthritis: results from the First National Health and Nutrition Examination Survey and its epidemiological follow-up study. J Clin Periodontol. 2011;38(11):9981006.

120. Harvey GP, Fitzsimmons TR, Dhamarpatni AASSK, Marchant C, Haynes DR, Bartold PM. Expression of peptidylarginine deiminase-2 and -4, citrullinated proteins and anti-citrullinated protein antibodies in human gingiva. J Periodontal Res. 2013;48(2):252-61.

121. Engström M, Eriksson K, Lee L, Hermansson M, Johansson A, Nicholas AP, et al. Increased citrullination and expression of peptidylarginine deiminases independently of $\mathrm{P}$. gingivalis and A. actinomycetemcomitans in gingival tissue of patients with periodontitis. J Transl Med. 2018;16(1):214.

122. Nesse W, Westra J, van der Wal JE, Abbas F, Nicholas AP, Vissink A, et al. The periodontium of periodontitis patients contains citrullinated proteins which may play a role in ACPA (anti-citrullinated protein antibody) formation. J Clin Periodontol. 2012;39(7):599-607.

123. Hitchon CA, Chandad F, Ferucci ED, Willemze A, IoanFacsinay A, van der Woude D, et al. Antibodies to porphyromonas gingivalis are associated with anticitrullinated protein antibodies in patients with rheumatoid arthritis and their relatives. J Rheumatol. 2010;37(6):1105-12.

124. Bae SC, Lee YH. Association between anti-Porphyromonas gingivalis antibody, anti-citrullinated protein antibodies, and rheumatoid arthritis : A meta-analysis. Z Rheumatol. 2018;77(6):52232.

125 .

Arvikar SL, Collier DS, Fisher MC, Unizony S, Cohen GL, McHugh G, et al. Clinical correlations with Porphyromonas gingivalis antibody responses in patients with early rheumatoid arthritis. Arthritis Res Ther. 2013;15(5):R109.

126. Mankia K, Cheng Z, Do T, Hunt L, Meade J, Kang J, et al. Prevalence of Periodontal Disease and Periodontopathic Bacteria in 
Anti-Cyclic Citrullinated Protein Antibody-Positive At-Risk Adults Without Arthritis. JAMA Netw Open. 2019;2(6):e195394.

127. Mariette X, Perrodeau E, Verner C, Struillou X, Picard N, Schaeverbeke T, et al. Role of good oral hygiene on clinical evolution of rheumatoid arthritis: a randomized study nested in the ESPOIR cohort. Rheumatology (Oxford). 2020;59(5):988-96.

128. Tajik N, Frech M, Schulz O, Schälter F, Lucas S, Azizov V, et al. Targeting zonulin and intestinal epithelial barrier function to prevent onset of arthritis. Nat Commun. 2020;11(1):1995.

129. Janssen KMJ, Hop H, Vissink A, Dijkstra G, de Smit MJ, Brouwer E, et al. Levels of Anti-Citrullinated Protein Antibodies and Rheumatoid Factor, Including IgA Isotypes, and Articular Manifestations in Ulcerative Colitis and Crohn's Disease. Int J Environ Res Public Health. 2020;17(21):8054.

130. Häger J, Bang H, Hagen M, Frech M, Träger P, Sokolova MV, et al. The Role of Dietary Fiber in Rheumatoid Arthritis Patients: A Feasibility Study. Nutrients. 2019;11(10):2392.

131. Martinsson K, Durholz K, Schett G, Zaiss MM, Kastbom A. Higher serum levels of short-chain fatty acids are associated with nonprogression to arthritis in individuals at increased risk of RA. Ann Rheum Dis. 2022;81(3):445-7.

132. Prevoo ML, van 't Hof MA, Kuper HH, van Leeuwen MA, van de Putte LB, van Riel PL. Modified disease activity scores that include twenty-eight-joint counts. Development and validation in a prospective longitudinal study of patients with rheumatoid arthritis. Arthritis Rheum. 1995;38(1):44-8.

133. Ekdahl C, Eberhardt K, Andersson SI, Svensson B. Assessing disability in patients with rheumatoid arthritis. Use of a Swedish version of the Stanford Health Assessment Questionnaire. Scand J Rheumatol. 1988;17(4):263-71.

134. Larsen A. How to apply Larsen score in evaluating radiographs of rheumatoid arthritis in long-term studies. $\mathrm{J}$ Rheumatol. 1995;22(10):1974-5.

135. Hallert E, Husberg M, Kalkan A, Rahmqvist M, Skogh T, Bernfort L. Changes in sociodemographic characteristics at baseline in two Swedish cohorts of patients with early rheumatoid arthritis diagnosed 1996-98 and 2006-09. Scand J Rheumatol. 2015;44(2):1005 .

136. Roos Ljungberg K, Börjesson E, Martinsson K, Wetterö J, Kastbom A, Svärd A. Presence of salivary IgA anti-citrullinated protein antibodies associate with higher disease activity in patients with rheumatoid arthritis. Arthritis Res Ther. 2020;22(1):274. 
137.

van Delft MAM, van der Woude D, Toes REM, Trouw LA.

Secretory form of rheumatoid arthritis-associated autoantibodies in serum are mainly of the IgM isotype, suggesting a continuous reactivation of autoantibody responses at mucosal surfaces. Ann Rheum Dis. 2019;78(1):146-8.

138. Svärd A, Roos Ljungberg K, Brink M, Martinsson K, Sjöwall C, Rantapää Dahlqvist S, et al. Secretory antibodies to citrullinated peptides in plasma and saliva from rheumatoid arthritis patients and their unaffected first-degree relatives. Clin Exp Immunol. 2020;199(2):143-9.

139. Kett K, Brandtzaeg P, Radl J, Haaijman JJ. Different subclass distribution of IgA-producing cells in human lymphoid organs and various secretory tissues. J Immunol. 1986;136(10):3631-5.

140. Brandtzaeg P. Do salivary antibodies reliably reflect both mucosal and systemic immunity? Ann N Y Acad Sci. 2007;1098:288-311. 141. Martinsson K, Roos Ljungberg K, Ziegelasch M, Cedergren J, Eriksson P, Klimovich V, et al. Elevated free secretory component in early rheumatoid arthritis and prior to arthritis development in patients at increased risk. Rheumatology (Oxford). 2020;59(5):979-87.

142. Matysiak-Budnik T, Moura IC, Arcos-Fajardo M, Lebreton C, Menard S, Candalh C, et al. Secretory IgA mediates retrotranscytosis of intact gliadin peptides via the transferrin receptor in celiac disease. $\mathrm{J}$ Exp Med. 2008;205(1):143-54.

143. Rey J, Garin N, Spertini F, Corthesy B. Targeting of secretory IgA to Peyer's patch dendritic and T cells after transport by intestinal M cells. J Immunol. 2004;172(5):3026-33.

144. Golpasand Hagh L, Zakavi F, Ansarifar S, Ghasemzadeh O, Solgi G. Association of dental caries and salivary sIgA with tobacco smoking. Aust Dent J. 2013;58(2):219-23.

145. van Gaalen FA, van Aken J, Huizinga TW, Schreuder GM, Breedveld FC, Zanelli E, et al. Association between HLA class II genes and autoantibodies to cyclic citrullinated peptides (CCPs) influences the severity of rheumatoid arthritis. Arthritis Rheum. 2004;50(7):2113-21. 146. Quirke AM, Perry E, Cartwright A, Kelly C, De Soyza A, Eggleton P, et al. Bronchiectasis is a Model for Chronic Bacterial Infection Inducing Autoimmunity in Rheumatoid Arthritis. Arthiritis Rheumatol. 2015;67(9):2335-42.

147. Perry E, Eggleton P, De Soyza A, Hutchinson D, Kelly C. Increased disease activity, severity and autoantibody positivity in rheumatoid arthritis patients with co-existent bronchiectasis. Int $\mathrm{J}$ Rheum Dis. 2017;20(12):2003-11.

148. Forslind K, Ahlmen M, Eberhardt K, Hafström I, Svensson B, Group BS. Prediction of radiological outcome in early rheumatoid 
arthritis in clinical practice: role of antibodies to citrullinated peptides (anti-CCP). Ann Rheum Dis. 2004;63(9):1090-5.

149. Makrygiannakis D, Hermansson M, Ulfgren AK, Nicholas AP, Zendman AJW, Eklund A, et al. Smoking increases peptidylarginine deiminase 2 enzyme expression in human lungs and increases citrullination in BAL cells. Ann Rheum Dis. 2008;67(10):1488-92.

150. Lugli EB, Correia RE, Fischer R, Lundberg K, Bracke KR, Montgomery $\mathrm{AB}$, et al. Expression of citrulline and homocitrulline residues in the lungs of non-smokers and smokers: implications for autoimmunity in rheumatoid arthritis. Arthritis Res Ther. 2015;17(1):9. 151. Giles JT, Danoff SK, Sokolove J, Wagner CA, Winchester R, Pappas DA, et al. Association of fine specificity and repertoire expansion of anticitrullinated peptide antibodies with rheumatoid arthritis associated interstitial lung disease. Ann Rheum Dis. 2014;73(8):148794.

152. Demoruelle MK, Wang H, Davis RL, Visser A, Hoang J, Norris JM, et al. Anti-peptidylarginine deiminase-4 antibodies at mucosal sites can activate peptidylarginine deiminase- 4 enzyme activity in rheumatoid arthritis. Arthritis Res Ther. 2021;23(1):163.

153. Svärd A, Renvert S, Sanmartin Berglund J, Persson RG, Söderlin M. Antibodies to citrullinated peptides in serum and saliva in patients with rheumatoid arthritis and their association to periodontitis. Clin Exp Rheumatol. 2020;38(4):699-704.

154. Martinsson K, Lyttbacka Kling L, Roos Ljungberg K, Griazeva I, Samoylovich M, Paul S, et al. Extramucosal formation and prognostic value of secretory antibodies in rheumatoid arthritis. Artritis Rheumatol. 2021:doi: 10.1002/art.42044.

155. Jones KP, Edwards JH, Reynolds SP, Peters TJ, Davies BH. A comparison of albumin and urea as reference markers in bronchoalveolar lavage fluid from patients with interstitial lung disease. Eur Respir J. 1990;3(2):152-6.

156. Nurkka A, Obiero J, Käyhty H, Scott JA. Effects of sample collection and storage methods on antipneumococcal immunoglobulin A in saliva. Clin Diagn Lab Immunol. 2003;10(3):357-61.

157. Grönblad EA. Concentration of immunoglobulins in human whole saliva: effect of physiological stimulation. Acta Odontol Scand. 1982;40(2):87-95.

158. Berens HM, Polinski KJ, Mikuls TR, Khatter S, August J, Visser A, et al. Anticyclic Citrullinated Peptide Antibodies 3.1 and AntiCCP-IgA Are Associated with Increasing Age in Individuals Without Rheumatoid Arthritis. J Rheumatol. 2019;46(12):1556-9. 
159. Demoruelle MK. Mucosa Biology and the Development of Rheumatoid Arthritis: Potential for Prevention by Targeting Mucosal Processes. Clin Ther. 2019;41(7):1270-8.

160. Kawaguchi H, Matsumoto I, Osada A, Kurata I, Ebe H, Tanaka Y, et al. Peptidyl arginine deiminase inhibition suppresses arthritis via decreased protein citrullination in joints and serum with the downregulation of interleukin-6. Mod Rheumatol. 2019;29(6):964-9.

161. Willis VC, Gizinski AM, Banda NK, Causey CP, Knuckley B, Cordova KN, et al. N- $\alpha$-benzoyl-N5-(2-chloro-1-iminoethyl)-L-ornithine amide, a protein arginine deiminase inhibitor, reduces the severity of murine collagen-induced arthritis. J Immunol. 2011;186(7):4396-404. 162. Hensvold AH, Frisell T, Magnusson PK, Holmdahl R, Askling J, Catrina AI. How well do ACPA discriminate and predict RA in the general population: a study based on 12590 populationrepresentative Swedish twins. Ann Rheum Dis. 2017;76(1):119-25.

163. Ramos-Remus C, Castillo-Ortiz JD, Aguilar-Lozano L, Padilla-Ibarra J, Sandoval-Castro C, Vargas-Serafin CO, et al. Autoantibodies in prediction of the development of rheumatoid arthritis among healthy relatives of patients with the disease. Artritis Rheumatol. 2015;67(11):2837-44.

164. Tanner S, Dufault B, Smolik I, Meng X, Anaparti V, Hitchon C, et al. A Prospective Study of the Development of Inflammatory Arthritis in the Family Members of Indigenous North American People With Rheumatoid Arthritis. Artritis Rheumatol. 2019;71(9):1494-503.

165. Alpizar-Rodriguez D, Mueller RB, Möller B, Dudler J, Ciurea A, Zufferey P, et al. Female hormonal factors and the development of anti-citrullinated protein antibodies in women at risk of rheumatoid arthritis. Rheumatology (Oxford). 2017;56(9):1579-85. 



PAPER 



\title{
Circulating secretory $\lg A$ antibodies against cyclic citrullinated peptides in early rheumatoid arthritis associate with inflammatory activity and smoking
}

Karin Roos ${ }^{1}$, Klara Martinsson', Michael Ziegelasch', Yngve Sommarin², Anna Svärd ${ }^{1,3}$, Thomas Skogh ${ }^{1}$ and Alf Kastbom ${ }^{1 *}$

\begin{abstract}
Background: A possible association between mucosal immunization and inflammation, as well as the initiation and propagation of rheumatoid arthritis (RA), is attracting renewed interest. The aim of this study was to evaluate the possible occurrence and clinical correlations of circulating secretory immunoglobulin A (SlgA) antibodies against the second-generation cyclic citrullinated peptides (CCP) among patients with recent-onset RA followed prospectively over 3 years.

Methods: Baseline serum samples from 636 patients with recent-onset RA were analyzed for SIgA anti-CCP antibodies by using an enzyme-linked immunosorbent assay with a secondary antibody directed against secretory component. SIgA anti-CCP status at baseline was analyzed in relation to smoking, HLA-DRB1/shared epitope (SE), and the disease course over 3 years. Significant findings were evaluated in regression analysis that included age, sex, smoking, and SE.

Results: Seventeen percent of the patients tested positive for circulating SIgA anti-CCP, and the occurrence was confirmed by detection of secretory component in an affinity-purified IgA anti-CCP fraction. SIgA anti-CCP positivity at baseline was associated with slightly higher baseline erythrocyte sedimentation rate (ESR) (mean 38 vs. $31 \mathrm{~mm} /$ first hour, $p=0.004$ ) and C-reactive protein (CRP) (mean 30 vs. $23 \mathrm{mg} / \mathrm{L}, p=0.047$ ). During follow-up, SlgA anti-CCP-positive patients had a higher mean AUC regarding ESR (adjusted $p=0.003$ ), although there were no significant differences regarding CRP, tender and swollen joint counts, or radiological joint damage (median Larsen progression 1.0 vs. 1.0, $p=0.22$ ). SlgA anti-CCP was associated significantly with smoking (79 \% ever smokers among SIgA anti-CCP-positive patients vs. $59 \%$ in SIgA anti-CCP-negative patients, adjusted OR 2.19, 95 \% Cl 1.01-4.37, $p=0.027$ ) but not with carriage of the SE ( $80 \%$ vs. $73 \%, p=0.62$ ).

Conclusions: Circulating SIgA anti-CCP, which is present in a subgroup of patients with early RA, is not related to SE, but it is environmentally linked to cigarette smoking. This finding strengthens the hypothesis that immunization against citrullinated peptides and/or proteins may occur at mucosal surfaces of the airways. Analysis of SlgA antibodies in serum may be a convenient and more versatile means to investigate the "mucosal connection" in RA compared with analyses in mucosal fluid samples.
\end{abstract}

Keywords: Rheumatoid arthritis, Anticitrullinated protein antibodies, Secretory immunoglobulin A, Mucosal immunity

\footnotetext{
* Correspondence: alf.kastbom@liu.se

'Division of Rheumatology, Department of Clinical and Experimental

Medicine, Linköping University, Linköping, Sweden

Full list of author information is available at the end of the article
} 


\section{Background}

Anti-citrullinated protein antibodies (ACPA) of both the IgG and IgA classes are commonly found in both synovial fluid and the circulation of patients with rheumatoid arthritis (RA) [1, 2], and they are highly specific for the disease [3]. The occurrence of circulating immunoglobulin A (IgA), IgM, and/or IgG ACPA often precedes a clinical diagnosis of RA $[4,5]$, but it is seldom induced after disease onset $[6,7]$. Although a large number of citrullinated autoantigens have been described, the most commonly used ACPA test detects IgG class antibodies to synthetic cyclic citrullinated peptides (CCP).

In recent years, the possible association between mucosal immunity and the initiation and propagation of RA has attracted renewed interest. For instance, chronic inflammation of the periodontium (i.e., periodontitis [PD]) associates with ACPA-positive RA, and patients with both conditions have more severe disease than patients with RA without PD [8, 9]. Also, IgG class serum antibodies to the PD-associated bacterium Porphyromonas gingivalis have been shown to correlate with serum levels of IgM and IgG2 anti-CCP levels [10] as well as with more active early disease [11]. IgG anti-CCP may be found in fluid from gingival crevices of patients with PD [12], and IgA anti-CCP antibodies have been demonstrated in saliva from patients with RA [13].

Involvement of airway mucosal surfaces in ACPA induction, and subsequent RA development is frequently brought forward, originally based on the epidemiological connection between inhaled toxic agents (e.g., cigarette smoke and silica) and an increased risk of ACPA-positive RA [14-16]. Further support is provided by the findings of ACPA enrichment in sputum and bronchoalveolar fluid $[17,18]$ as signs of local autoantibody production, as well as by the identification of identical citrullinated autoantigens in both lungs and joints of patients with RA [19]. Also, radiological parenchymal abnormalities of the lungs are more common in ACPA-positive individuals compared with those who are ACPA-negative, regardless of smoking and RA status $[17,20]$.

Mucosal immunity of the gastrointestinal tract regained attention when it was shown in the early 1990s that induction of oral tolerance to type II collagen could alleviate arthritis in mice and humans, although later the therapeutic effect in humans was found to be disappointing [21]. Later work has been focused on interactions with the gut microbiome, where manipulations of the intestinal microbiota were shown to influence arthritis severity in several animal models [22, 23]. Interestingly, patients with RA have been reported to have an altered fecal microbiota compared with disease controls [24], and anti-CCP antibodies and increased total secretory IgA (SIgA) levels have been demonstrated in feces [25].
SIgA is produced at mucosal surfaces, but it can also be detected in low concentrations in the systemic circulation [26]. In contrast to circulating $\operatorname{IgA}$, which is mostly monomeric, SIgA is mainly dimeric and complexed with a secretory component (SC) (i.e., a remnant of the polymeric immunoglobulin receptor responsible for the active transport of antibodies across mucosal membranes) [27]. Eijgenraam et al. reported antigenspecific SIgA in serum after mucosal immunization with cholera toxin subunit B [28]. Thus, mucosal immunization in autoimmune diseases could potentially be investigated by analysis of SIgA autoantibodies in serum, enabling more convenient sample handling, more reliable quantitative analyses, and access to larger patient cohorts compared with what is achievable regarding mucosal secretions.

Before the discovery of ACPA, rheumatoid factor (RF) was the predominant serologic marker of RA. RF of IgA class has repeatedly been associated with smoking and with more severe disease [29-31]. Also, RF complexed with SC has been detected in RA, but the predictive value of these antibodies was not evaluated [32]. The aim of this study was to detect SIgA anti-CCP in sera from patients with RA and to determine its relationship to disease course, cigarette smoking, and genetic (HLADRB1) risk factors.

\section{Methods}

\section{Study subjects}

Two prospective Swedish early RA cohorts, designated "timely interventions in RA" (TIRA), formed the basis of the present study [33]. The prerequisites for inclusion were symptom duration $\geq 6$ weeks but $<12$ months since the first joint swelling as judged by the patient, as well as the following:

- Fulfillment of at least four of seven of the 1987 revised American College of Rheumatology criteria for RA [34] $(n=605$ [95.1\%]) or

- Morning stiffness for $\geq 60$ minutes and symmetrical arthritis and small joint arthritis (fingers, wrists, or toes) $(n=31[4.9 \%])$

TIRA-1 patients were enrolled between 1996 and 1998 and prospectively followed with longitudinal assessments of 28-joint Disease Activity Score (DAS28) [35], erythrocyte sedimentation rate (ESR), C-reactive protein (CRP), the Swedish version of the Health Assessment Questionnaire [36], and information regarding ongoing disease-modifying antirheumatic drugs(DMARDs). Smoking habits were assessed by questionnaires as previously described [37].

TIRA-2 patients were enrolled between 2006 and 2008 with identical inclusion criteria and follow-up procedures as those used for TIRA-1, except that yearly 
radiographs of the hands and feet from baseline were obtained and graded for joint damage according to the Larsen score [38]. Smoking habits were assessed either with a questionnaire provided by the Epidemiological Investigations of RA Study $(n=207)$ [39] or by chart review $(n=58)$.

Table 1 summarizes the baseline characteristics of both cohorts. Baseline serum samples were available from 197 (62.1\%) of 317 TIRA-1 patients and from 439 (97.1\%) of 452 TIRA-2 patients. There were no significant differences in clinical characteristics between patients who had samples available compared with those without. All patients gave their written informed consent to participate, and the ethics committee in Linköping, Sweden, approved the study protocols.

\section{Isotype-specific enzyme-linked immunoassays}

Serum samples $(n=636)$ taken at inclusion were analyzed for anti-CCP of SIgA isotype using a modification of the commercially available IgG class anti-CCP2 enzyme-linked immunosorbent assay (ELISA) (CCPlus ${ }^{\circ}$ Immunoscan; Euro Diagnostica $\mathrm{AB}$, Malmö, Sweden). Serum samples were stored at $-70{ }^{\circ} \mathrm{C}$ until analysis. The sera were diluted 1:25 with kit buffer and added in duplicate wells. An RA reference serum with high SIgA anti-CCP level was applied in dilution series (1:12.5 to $1: 800$ ) to achieve a standard curve and subsequent conversion of the results into arbitrary units (AU) per milliliter. Incubations and rinsing were done according to the kit manufacturer's guidelines. A polyclonal goat IgG antihuman secretory component (GAHU/SC/PO; Nordic BioSite, Täby, Sweden) diluted 1:2000 in kit buffer was used as a secondary antibody. Absorbance was read by spectrophotometry at $450 \mathrm{~nm}$ (TECAN Sunrise software, Magellan V7.1; Tecan Nordic AB, Mölndal,

Table 1 Baseline characteristics

\begin{tabular}{|c|c|}
\hline Characteristics & TIRA cohorts $(n=636)$ \\
\hline Women & $426 / 636(67.0 \%)$ \\
\hline Mean age, years (SD) & $57.6(15.0)$ \\
\hline Median baseline Larsen score ${ }^{a}(\mathrm{QQR})$ & $2.0(4.3)$ \\
\hline RF-positive & $387 / 636(60.8 \%)$ \\
\hline IgG anti-CCP-positive & $421 / 622(67.7 \%)$ \\
\hline IgA anti-CCP-positive & 251/635 (39.5 \%) \\
\hline SIgA anti-CCP-positive & $110 / 636(17.3 \%)$ \\
\hline Median baseline HAQ (IQR) & $0.9(0.6)$ \\
\hline Any baseline DMARD & $504 / 631(79.9 \%)$ \\
\hline \multicolumn{2}{|c|}{$\begin{array}{l}\text { TIRA Swedish acronym for "timely interventions in rheumatoid arthritis", } \\
C C P \text { cyclic citrullinated peptides, } R F \text { rheumatoid factor, DMARD disease-modifying } \\
\text { antirheumatic drug, IQR interquartile range, IgG immunoglobulin G, } \\
\text { IgA immunoglobulin A, SIgA secretory immunoglobulin A, HAQ Health } \\
\text { Assessment Questionnaire } \\
\text { Values are number (\%) of patients unless otherwise indicated } \\
\text { aData available from } 398 \text { patients }\end{array}$} \\
\hline
\end{tabular}

Sweden). IgG and IgA anti-CCP antibodies in TIRA-1 were analyzed by ELISAs as previously described $[6,40]$ and in TIRA-2 by ELISA for IgG anti-CCP (CCPlus ${ }^{\circ}$ Immunoscan) and by fluorescence enzyme immunoassays on the Phadia 250 instrument (EliA; Thermo Fisher AB, Uppsala, Sweden) for IgA anti-CCP. The cutoffs for a positive SIgA anti-CCP antibody test were set to $153 \mathrm{AU} / \mathrm{ml}$ and to $\geq 2 \mu \mathrm{g} / \mathrm{L}$ for the IgA antiCCP EliA, both above the 99th percentile among 101 healthy blood donors. Regarding IgG anti-CCP antibodies, we used the cutoff level suggested by the manufacturer $(25 \mathrm{AU} / \mathrm{ml})$. Citrulline specificity of the SIgA anti-CCP method was tested by analyzing ten RA serum samples on microtiter plates coated with cyclic arginine peptides (CAP) (Euro Diagnostica $\mathrm{AB}$ ) as well as on plates coated with CCP. In total, 621 of 636 serum samples were analyzed regarding all 3 anti-CCP isotypes (IgG, IgA, and SIgA).

\section{Antibody affinity purification}

Anti-CCP antibodies of IgA and IgG class were isolated from a highly positive serum sample by affinity chromatography using aCCP column (Euro Diagnostica $\mathrm{AB}$ ). The sample was filtered through a $0.2-\mu \mathrm{m}$ pore size filter and then added to the column. Bound antibodies were eluted using $0.1 \mathrm{M}$ glycine $(\mathrm{pH} 2.7)$ and immediately neutralized with $1 \mathrm{M}$ Tris ( $\mathrm{pH}$ 9.0). The CCP-specific antibodies were then added to a protein $\mathrm{G}$ column (Pierce Biotechnology, Rockford, IL, USA), and the IgG class anti-CCP antibodies were eluted in $0.3-\mathrm{ml}$ aliquots using IgG elution buffer (Pierce Biotechnology). The flow-through (containing IgA class anti-CCP antibodies) was added to a Peptide M column (InvivoGen, San Diego, CA, USA), and the IgA class anti-CCP antibodies were eluted (in 0.3-ml aliquots) using $0.1 \mathrm{M}$ sodium acetate $(\mathrm{pH} 4.0)$. Immediately after elution, both IgG and IgA class anti-CCP antibodies were neutralized with $1 \mathrm{M}$ Tris- $\mathrm{HCl}(\mathrm{pH}$ 8.3). The purified antibodies were stored at $-20{ }^{\circ} \mathrm{C}$ until further use.

\section{Western blot analysis}

The samples were mixed 50:50 with Laemmli buffer containing 2- $\beta$-mercaptoethanol and heated to $95{ }^{\circ} \mathrm{C}$ for 5 minutes. The purified anti-CCP antibodies were diluted to $0.14 \mu \mathrm{g} / \mathrm{ml}$, and $35 \mu \mathrm{l}$ of each sample was added to the wells of a $10 \%$ SDS-PAGE gel (Bio-Rad Laboratories, Hercules, CA, USA), which was run for 90 minutes at 180 V (PowerPac HC; Bio-Rad Laboratories). Precision Plus Protein WesternC Standard (Bio-Rad Laboratories) was used as a molecular weight marker. Following electrophoresis, the antibodies were transferred to a nitrocellulose membrane (Bio-Rad Laboratories) presoaked in Towbin buffer. Blotting was carried out using the Bio-Rad PowerPac $\mathrm{HC}$ for 30 minutes at $80 \mathrm{~V}$. The membrane was washed and blocked using $5 \%$ fat-free milk 
powder (Bio-Rad Laboratories) for $1 \mathrm{~h}$. After blocking, the membrane was placed in Tris-buffered saline (TBS) with $0.05 \%$ Tween-20 (TBS-T) for 5 minutes. The molecular weight marker was cut out and transferred to a container with the detection antibody (Bio-Rad Laboratories) diluted 1:60,000 in TBS-T and incubated for 30 minutes, followed by washing in TBS-T and TBS. The rest of the membrane was transferred to a container with the SIgA detection antibody (GAHU/SC/PO; Nordic BioSite) diluted to 1:50,000 in TBS-T and incubated overnight at $4{ }^{\circ} \mathrm{C}$. Thereafter, the membrane was washed in TBS-T and TBS, mounted and incubated for 1 minute with the substrate (ECL Prime Western Blotting Detection Reagent; GE Healthcare Life Sciences, Little Chalfont, UK). The membrane was exposed for 1 minute (high-performance chemiluminescence film; GE Healthcare Life Sciences), and the film was developed and fixed using D-19 Silver (Kodak, Rochester, NY, USA) and Fixer (Kodak).

\section{Genetic analyses}

In TIRA-1, genotyping of HLA-DRB1 was performed by polymerase chain reaction amplification with sequencespecific primers (GenoVision, Oslo, Norway); in TIRA-2, it was carried out by Sanger sequencing (BGI Clinical Laboratories, Shenzhen, China). In both cohorts, shared epitope (SE) was defined as HLA-DRB1"01, "0401, "0404,
"0405, "0408, "0409, *0410, *0413, *0416, "0419, *0421, or $* 10$.

\section{Statistics}

Clinical and laboratory measurements of disease severity (e.g., ESR, CRP, and DAS28) were compared by using Student's $t$ test at baseline, and during follow-up by calculating AUC for months 0-36. Missing values were assumed to occur at random, and, unless this occurred during the more dynamic first 6 months (which resulted in exclusion from the analysis), we adopted the last observation carried forward, which occurred in $4.4 \%$ of the occasions. Student's $t$ test was used to compare AUC between patients testing positive versus negative regarding anti-CCP antibodies of each isotype. Linear regression analysis was performed to evaluate the association between SIgA anti-CCP and ESR adjusted for age, sex, and carriage of SE. As IgG anti-CCP is well known to associate with the disease course in early RA, and since SIgA/IgA anti-CCP antibodies almost exclusively occur in IgG anti-CCP-positive patients, we chose to evaluate the influence of SIgA and IgA anti-CCP antibodies on disease course and pharmacotherapy in IgG anti-CCPpositive patients only.

The Mann-Whitney $U$ test was applied to evaluate differences between anti-CCP levels and radiological joint

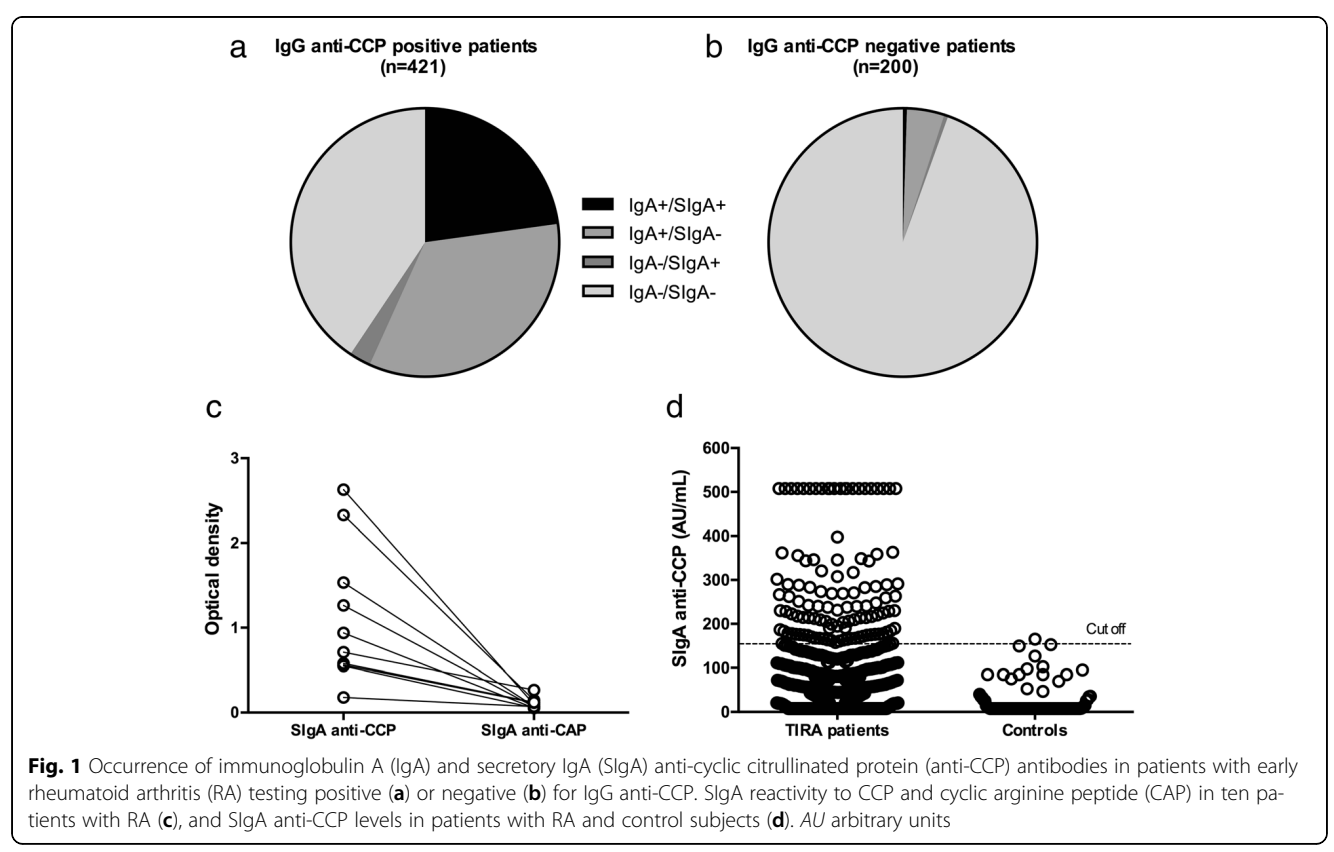


damage. Spearman's correlation $(\rho)$ was used to evaluate correlations between levels of SIgA anti-CCP, other ACPA isotypes, and baseline disease activity measures. Fisher's exact test was performed to test differences in the occurrence of SE and smoking. Also, the association between smoking and SIgA anti-CCP was tested in a logistic regression analysis, adjusting for age, sex, and carriage of SE. Statistical analyses were performed using IBM SPSS 22.0 software (IBM, Armonk, NY, USA), and two-sided $p$ values less than 0.05 were considered significant.

\section{Results}

\section{Occurrence of SlgA anti-CCP}

As measured by ELISA, circulating SIgA anti-CCP occurred in 29 (14.7\%) TIRA-1 patients and 81 (18.5\%) TIRA-2 patients, respectively (17.3\% occurrence in total) (Fig. 1a-d). Among patients with IgG anti-CCP antibodies, $25.4 \%$ also had SIgA anti-CCP antibodies, while IgA anti-CCP antibodies occurred in $38.6 \%$ (Fig. 1a, b). SIgA anti-CCP and IgA anti-CCP were both rare in the absence of IgG anti-CCP antibodies (occurring in 2 and 10 patients, respectively). Ninety-six (15.5\%) of six hundred twenty-one of the patients tested positive for all analyzed isotypes.

Citrulline-dependent specificity of the SIgA antibodies was evaluated by testing the reactivity to CAP control plates in ten anti-CCP-positive serum samples. The median optical density (OD) for SIgA anti-CAP was 0.09 (range 0.05-0.27), and the median OD for SIgA anti-CCP was 0.83 (range 0.18-2.63) for the same serum samples (Fig. 1c). No SIgA anti-CAP value exceeded $40 \%$ of the corresponding SIgA anti-CCP OD. SIgA anti-CCP levels correlated significantly with IgG anti-CCP $(\rho=0.70$, $p<0.001)$ and with levels of IgA anti-CCP $(\rho=0.69$ in TIRA- 1 and $\rho=0.64$ in TIRA-2, $p<0.001$ for both; cohorts presented separately because of different detection methods used).

To confirm the presence of circulating SIgA anti-CCP, we performed Western blot analysis to detect SC in affinity-purified anti-CCP antibodies from IgG and IgA fractions of patient sera. In the IgA anti-CCP eluate, an $80 \mathrm{kDa}$ band appeared, corresponding to the molecular weight of SC [27], while no band was visible in the IgG anti-CCP fraction (Fig. 2).

\section{Circulating SIgA anti-CCP and disease outcome}

A modest but statistically significant correlation was observed between levels of SIgA anti-CCP and ESR at baseline $(\rho=0.09, p=0.02)$, while the number of tender and swollen joints at baseline tended to be inversely correlated with SIgA anti-CCP levels $(\rho=-0.12$, $p=0.002$, and $\rho=-0.08, p=0.038$, respectively). There

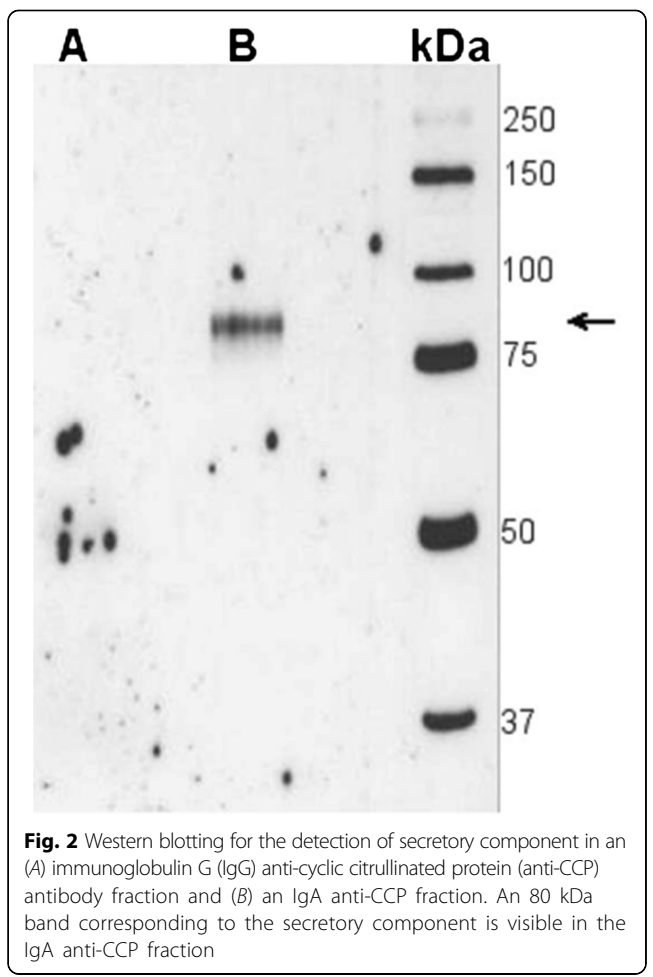

were no significant correlations regarding baseline DAS28 $(\rho=-0.06, p=0.15)$ or CRP $(\rho=-0.02, p=0.65)$.

As IgG anti-CCP antibody status is known to predict the disease course [6] and therefore may influence therapeutic decisions in early RA, and since SIgA anti-CCP almost exclusively occurs in IgG anti-CCP-positive patients, we chose to perform analyses of disease severity only among the IgG anti-CCP-positive patients. Patients testing positive regarding SIgA (and IgG) anti-CCP had higher mean baseline CRP and ESR levels than the patients negative for SIgA (but still positive regarding IgG) anti-CCP (CRP 29.9 vs. $22.7 \mathrm{mg} / \mathrm{L}, p=0.047$; ESR 38.0 vs. $30.8 \mathrm{~mm} /$ first hour, $p=0.004)$. There were no significant differences between the two groups regarding baseline DAS28 (5.1 vs. 5.1, $p=0.57$ ), tender joint count (7.1 vs. 7.9, $p=0.24$ ), or swollen joint count (8.1 vs. 7.9, $p=0.73)$. Patients testing positive for SIgA anti-CCP had higher baseline levels of both IgG and IgA anti-CCP than SIgA-negative patients (median IgG in TIRA-1 1270 vs. $424 \mathrm{AU} / \mathrm{ml}, p<0.001$; median IgA in TIRA-1 77.5 vs. $58.5 \mathrm{AU} / \mathrm{ml}, p<0.001$; median IgA in TIRA-2 10.5 vs. $5.5 \mu \mathrm{g} / \mathrm{L}, p<0.001)$. 
As seen in Fig. 3, comparison of AUC for the 3-year follow-up period revealed significantly higher mean ESR among SIgA-positive patients $(p=0.005)$ but no significant differences regarding CRP, DAS28, and swollen or tender joint count. In univariate analyses of IgG antiCCP-positive patients, SIgA anti-CCP status and age (but not sex, smoking, or SE) were significantly associated with AUC ESR. In a linear regression analysis adjusting for age, SIgA anti-CCP positivity remained significantly associated with higher mean AUC for ESR $(p=0.003)$. In a similar model, but analyzing absolute values at the 3-year follow-up, SIgA anti-CCP positivity was associated with a $5.0 \mathrm{~mm} /$ first hour increase in ESR
(95 \% CI 0.7-9.2) compared with SIgA anti-CCPnegative patients.

IgA anti-CCP status was evaluated using the same approach, and no significant differences were detected in AUC of the above-mentioned disease activity measures (data not shown). The proportion of patients prescribed DMARD or nonsteroidal anti-inflammatory drug (NSAID) treatment did not differ between SIgA-positive and SIgAnegative patients at any of the follow-up visits (data not shown). Radiological joint damage in the TIRA-2 cohort did not significantly differ between SIgA anti-CCP-positive and SIgA anti-CCP-negative patients at baseline (median Larsen score 2.0 vs. 2.0, $p=0.61$ ) or at the 3 -year follow-

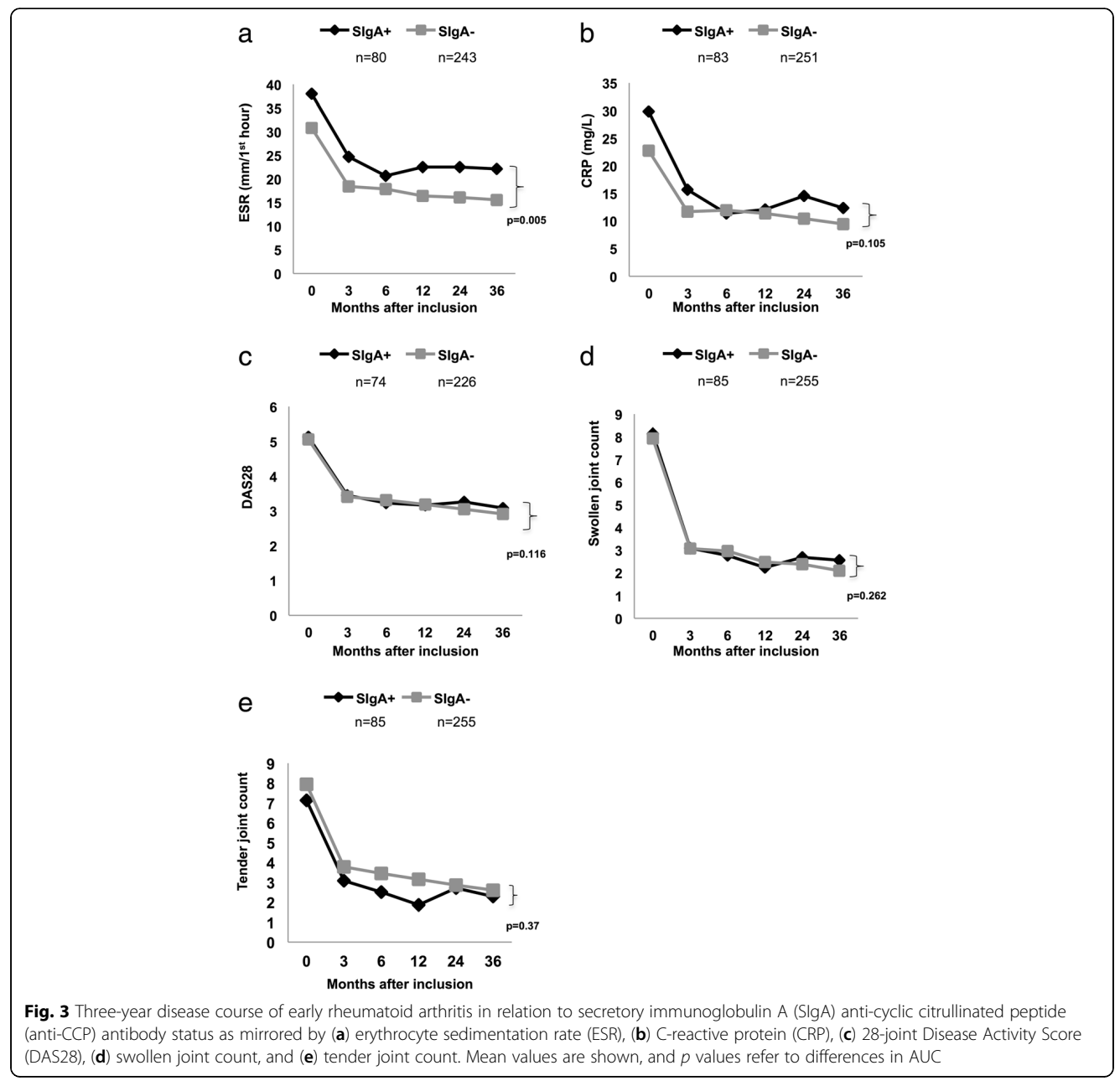




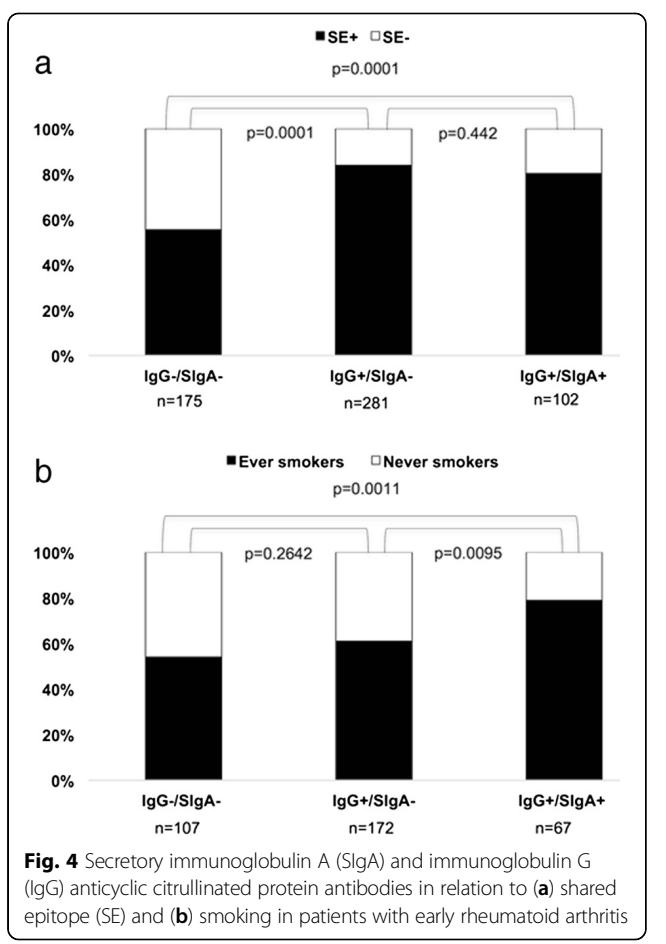

up visit ( 2.5 vs. $4.0, p=0.42)$. Likewise, there was no difference in median Larsen score progression over 3 years (1.0 vs. $1.0, p=0.22$ ).

Circulating SIgA anti-CCP in relation to HLA-DRB1/shared epitope and smoking habit

At least one SE allele was present in 83 (80\%) of the SIgA anti-CCP patients and in 340 (73\%) of the SIgA anti-CCP-negative patients. As seen in Fig. 4a, carriage of SE was associated with IgG anti-CCP antibodies ( $p=0.0001)$ but not with the co-occurrence of SIgA antiCCP $(p=0.44)$. Smoking habits were analyzed in the same way as SE (Fig. 4b), where 53 (79 \%) of the SIgA antiCCP-positive patients were ever smokers, compared with 168 (59 \%) of the SIgA-negative patients. Ever smoking was associated with the presence of SIgA anti-CCP antibodies ( $p=0.0095)$, while IgG anti-CCP antibodies (in the absence of SIgA anti-CCP) was not $(p=0.26)$. Smoking was significantly associated with the presence of SIgA anti-CCP (OR 2.19, 95 \% CI 1.01-4.37, $p=0.027$ ), also after adjusting for age, sex, and SE (Table 2).

\section{Discussion}

In this study of well-characterized patients with early RA, we present the novel finding of circulating SIgA anti-CCP and describe its relationship to disease severity and etiological factors. Unlike IgG anti-CCP, circulating SIgA anti-CCP is not genetically related to SE, but is environmentally linked to cigarette smoking. This corresponds well to our previous studies regarding serum IgA ACPA, in which detection antibodies to $\alpha$-chains were used and thus, as monomeric IgA predominates in the circulation, mainly concern nonsecretory $\operatorname{IgA}[16,40]$. Although secretory autoantibodies in sera from patients with other autoimmune diseases have been described earlier [32, 41], to the best of our knowledge this is the first report on SIgA ACPA in RA.

We found that approximately $25 \%$ of patients with early RA with IgG class anti-CCP antibodies also had circulating SIgA anti-CCP antibodies, a proportion that is lower than IgA anti-CCP antibodies (39\%), which supports the notion that nonsecretory forms of IgA antiCCP prevail in the circulation. The correlation between levels of SIgA anti-CCP and levels of IgG anti-CCP was found to be equally as strong as between SIgA and IgA anti-CCP. This somewhat surprising finding may suggest that mucosal immunization to citrullinated proteins is similarly important in systemic IgG and IgA ACPA responses in early RA. However, to enable firm conclusions regarding the temporal relationship between SIgA and other isotypes, serial analyses of preclinical cases are warranted. Also, it remains to be determined if and where mucosal immunization against citrullinated proteins occurs in $\mathrm{IgG}^{+} / \mathrm{IgA}^{-} / \mathrm{SIgA}^{-}$patients.

Table 2 Logistic regression analysis regarding secretory anti-cyclic citrullinated protein antibodies in patients with early rheumatoid arthritis

\begin{tabular}{|c|c|c|c|c|c|c|}
\hline \multirow[t]{2}{*}{ Variable } & \multicolumn{2}{|l|}{ SlgA anti-CCP } & \multicolumn{2}{|c|}{ Unadjusted } & \multicolumn{2}{|l|}{ Adjusted } \\
\hline & Positive & Negative & $p$ value & OR $(95 \% \mathrm{Cl})$ & $p$ value & OR (95\% Cl) \\
\hline Ever smoking & $49 / 63(78 \%)$ & $94 / 156(60 \%)$ & 0.015 & $2.31(1.18-4.53)$ & 0.027 & $2.19(1.01-4.37)$ \\
\hline One or two SE alleles & $51 / 63(81 \%)$ & 130/156 (83\%) & 0.674 & $0.85(0.40-1.81)$ & 0.819 & $0.91(0.42-2.00)$ \\
\hline Female sex & $44 / 63(70 \%)$ & $117 / 156(75 \%)$ & 0.434 & $1.30(0.68-2.48)$ & 0.814 & $1.09(0.55-2.14)$ \\
\hline Age at inclusion, years & 58.7 & 52.6 & 0.002 & $1.04(1.02-1.07)$ & 0.005 & $1.04(1.01-1.07)$ \\
\hline
\end{tabular}

SE Shared epitope, SIgA secretory immunoglobulin A, CCP cyclic citrullinated protein

Adjusted values are adjusted for all other variables in the table 
On the basis of our previous findings of a milder disease in patients with RA with salivary IgA anti-CCP [13], we anticipated that circulating SIgA anti-CCP would associate with lower disease activity at the time of sampling, and possibly over time in early disease. Instead, it turned out that SIgA anti-CCP-positive patients had higher ESR and CRP levels at baseline than SIgA anti-CCP-negative patients, and the difference remained significant over 3 years regarding ESR. Although these findings are in line with previous reports on IgA RF, we did not find any significant predictive value of IgA anti$\mathrm{CCP}$ in our cohorts. Intriguingly, while baseline inflammatory activity was higher in patients with SIgA antiCCP antibodies, the number of swollen and tender joints was inversely related to SIgA anti-CCP antibody levels at the time of sampling. This finding opens up for speculation that the laboratory markers of inflammation partly reflect mucosal inflammation and not merely synovitis. Instead, the inverse correlation between antibody levels and effects on joints could hypothetically reflect the downregulating potential of antigen exposure in the gastrointestinal tract (i.e., oral tolerance). However, this remains speculative, as the origin of circulating SIgA anti-CCP remains to be determined. Further, it is possible that SIgA anti-CCP correlates with total IgA levels, which in turn may influence the ESR without being related to inflammation. In view of the small differences in disease activity measures over time as well as the lack of association with radiological progression, we see no clinical reason at present for routine baseline testing of SIgA anti-CCP. We recently reported that IgA and SIgA antiproteinase 3 (PR3) antibodies are more closely related to disease activity than IgG anti-PR3 in antineutrophil cytoplasmic antibody-associated vasculitis [42]. Analogously, future work should evaluate changes in SIgA anti-CCP levels in relation to therapeutic responses. Also, serial SIgA anti-CCP analyses in serum from pre-RA patients are of obvious interest regarding mucosal involvement in disease development.

Passive transport over leaky, inflamed mucosal membranes could be one possibility by which SIgA is translocated from mucosal secretions to the systemic circulation. However, there are several examples of active retransportation of SIgA across mucosal membranes from the luminal side to the subepithelial compartment $[43,44]$ and even inducing systemic immunity [45], but how SIgA is further transferred into the circulation remains unknown.

Total SIgA levels in the circulation are elevated in patients with RA compared not only with healthy individuals but also with patients with ankylosing spondylitis (i.e., another rheumatic disease with mucosal pathogenic implications) [32, 46]. In line with previous work regarding SIgA [46], we found no relationship between SIgA anti-CCP levels and use of NSAIDs, suggesting that iatrogenic damage to mucosal membranes is not a major cause of SIgA occurrence in the circulation. Cigarette smoking, on the other hand, appears robustly associated with serum SIgA anti-CCP antibody occurrence, even after considering the presence of IgG anti-CCP. Although not explicitly addressed in the present study, this finding may suggest that the airway mucosa is a major contributor to serum SIgA anti-CCP. Paired samples of serum and mucosal fluid from patients with RA will be crucial to delineating the origin of serum SIgA ACPAs and to determining the pathogenic role of each mucosal compartment.

\section{Conclusions}

SIgA anti-CCP antibodies can be detected in serum from patients with RA and are associated with smoking and increased signs of systemic inflammation at the time of sampling.

\section{Acknowledgements}

We thank Dr. Åsa Reckner Olsson and the Epidemiological Investigation of RA (EIRA) study group for providing data on smoking habits in TIRA-1 and TIRA-2, respectively. Stefan Carlsén at Euro Diagnostica AB is acknowledged for expert technical assistance with antibody purification. We are also indebted to the TIRA participating centers of Eskilstuna, Jönköping, Kalmar, Lindesberg, Örebro, Västervik, Oskarshamn, and Falun. This study was supported by grants from King Gustav V's 80-year Foundation, the Swedish Medical Society, the Reinhold Sund Foundation, and the Östergötland County Council.

\section{Authors' contributions}

KR performed SIgA anti-CCP immunoassays and statistical analyses. KM carried out the antibody affinity purification and Western blot analysis. MZ performed scoring of radiographs. YS provided assistance regarding immunoassays and antibody purification. AS was involved in immunoassay development and statistical analyses. MZ, TS, and AK were responsible for patient enrollment and characterization. KR, KM, and AK drafted the manuscript. All authors participated in the study design, and reviewed and revised the manuscript critically. All authors read and approved the final manuscript.

\section{Competing interests}

YS is employed by Euro Diagnostica, Malmö, Sweden. All other authors declare that they have no competing interests.

\section{Author details}

'Division of Rheumatology, Department of Clinical and Experimental Medicine, Linköping University, Linköping, Sweden. ${ }^{2}$ Euro Diagnostica AB, Malmö, Sweden. ${ }^{3}$ Rheumatology Clinic, Falun Hospital, Falun, Sweden.

Received: 14 December 2015 Accepted: 6 May 2016 Published online: 23 May 2016

References

1. Kroot EJ, de Jong BA, van Leeuwen MA, Swinkels $\mathrm{H}$, van den Hoogen $\mathrm{FH}$, van 't Hof $M$, et al. The prognostic value of anti-cyclic citrullinated peptide antibody in patients with recent-onset rheumatoid arthritis. Arthritis Rheum. 2000;43:1831-5

2. Snir O, Widhe M, Hermansson M, von Spee C, Lindberg J, Hensen S, et al. Antibodies to several citrullinated antigens are enriched in the joints of rheumatoid arthritis patients. Arthritis Rheum. 2010;62:44-52.

3. Holers VM. Autoimmunity to citrullinated proteins and the initiation of rheumatoid arthritis. Curr Opin Immunol. 2013;25:728-35.

4. Nielen MM, van Schaardenburg D, Reesink HW, van de Stadt RJ, van der Horst-Bruinsma IE, de Koning $M H$, et al. Specific autoantibodies precede the symptoms of rheumatoid arthritis: a study of serial measurements in blood donors. Arthritis Rheum. 2004;50:380-6. 
5. Rantapää-Dahlqvist S, de Jong BA, Berglin E, Hallmans G, Wadell G, Stenlund H, et al. Antibodies against cyclic citrullinated peptide and IgA rheumatoid factor predict the development of rheumatoid arthritis. Arthritis Rheum. 2003:48:2741-9.

6. Kastbom A, Strandberg G, Lindroos A, Skogh T. Anti-CCP antibody test predicts the disease course during 3 years in early rheumatoid arthritis (the Swedish TIRA project). Ann Rheum Dis. 2004;63:1085-9.

7. Rönnelid J, Wick MC, Lampa J, Lindblad S, Nordmark B, Klareskog L, et al. Longitudinal analysis of citrullinated protein/peptide antibodies (anti-CP) during 5 year follow up in early rheumatoid arthritis: anti-CP status predicts worse disease activity and greater radiological progression. Ann Rheum Dis. 2005;64:1744-9.

8. Kaur S, White S, Bartold PM. Periodontal disease and rheumatoid arthritis: a systematic review. J Dent Res. 2013;92:399-408.

9. Mikuls TR, Payne JB, Yu F, Thiele GM, Reynolds RJ, Cannon GW, et al. Periodontitis and Porphyromonas gingivalis in patients with rheumatoid arthritis. Arthritis Rheumatol. 2014:66:1090-100.

10. Hitchon CA, Chandad F, Ferucci ED, Willemze A, loan-Facsinay A, van der Woude $\mathrm{D}$, et al. Antibodies to Porphyromonas gingivalis are associated with anticitrullinated protein antibodies in patients with rheumatoid arthritis and their relatives. J Rheumatol. 2010;37:1105-12.

11. Arvikar SL, Collier DS, Fisher MC, Unizony S, Cohen GL, McHugh G, et al. Clinical correlations with Porphyromonas gingivalis antibody responses in patients with early rheumatoid arthritis. Arthritis Res Ther. 2013;15:R109.

12. Harvey GP, Fitzsimmons TR, Dhamarpatni AASSK, Marchant C, Haynes DR, Bartold PM. Expression of peptidylarginine deiminase-2 and -4, citrullinated proteins and anti-citrullinated protein antibodies in human gingiva. J Periodontal Res. 2013;48:252-61

13. Svärd A, Kastbom A, Sommarin Y, Skogh T. Salivary lgA antibodies to cyclic citrullinated peptides (CCP) in rheumatoid arthritis. Immunobiology. 2013;218:232-7.

14. Klareskog L, Stolt P, Lundberg K, Kallberg H, Bengtsson C, Grunewald J, et al. A new model for an etiology of rheumatoid arthritis: smoking may trigger HLA-DR (shared epitope)-restricted immune reactions to autoantigens modified by citrullination. Arthritis Rheum. 2006;54:38-46.

15. Stolt P, Yahya A, Bengtsson C, Källberg H, Rönnelid J, Lundberg I, et al. Silica exposure among male current smokers is associated with a high risk of developing ACPA-positive rheumatoid arthritis. Ann Rheum Dis. 2010;69:1072-6.

16. Svärd A, Skogh T, Alfredsson L, llar A, Klareskog L, Bengtsson C, et al. Associations to smoking and shared epitope differ between $\lg A$ and $\lg G$ class antibodies to cyclic citrullinated peptides in early rheumatoid arthritis. Arthritis Rheumatol. 2015:67:2032-7.

17. Reynisdottir G, Karimi R, Joshua V, Olsen H, Hensvold AH, Harju A, et al. Structural changes and antibody enrichment in the lungs are early features of anti-citrullinated protein antibody-positive rheumatoid arthritis. Arthritis Rheumatol. 2014;66:31-9.

18. Willis VC, Demoruelle MK, Derber LA, Chartier-Logan CJ, Parish MC, Pedraza IF, et al. Sputum autoantibodies in patients with established rheumatoid arthritis and subjects at risk of future clinically apparent disease. Arthritis Rheum. 2013;65:2545-54.

19. Ytterberg AJ, Joshua V, Reynisdottir G, Tarasova NK, Rutishauser D, Ossipova E, et al. Shared immunological targets in the lungs and joints of patients with rheumatoid arthritis: identification and validation. Ann Rheum Dis. 2015:74:1772-7.

20. Demoruelle MK, Weisman MH, Simonian PL, Lynch DA, Sachs PB, Pedraza IF et al. Brief report: airways abnormalities and rheumatoid arthritis-related autoantibodies in subjects without arthritis: early injury or initiating site of autoimmunity? Arthritis Rheum. 2012;64:1756-61

21. Trentham DE. Oral tolerization as a treatment of rheumatoid arthritis. Rheum Dis Clin North Am. 1998:24:525-36.

22. Dorożyńska I, Majewska-Szczepanik M, Marcińska K, Szczepanik M. Partia depletion of natural gut flora by antibiotic aggravates collagen induced arthritis (CIA) in mice. Pharmacol Rep. 2014;66:250-5.

23. Ivanov II WHJ, Darce J, Hattori K, Shima T, Umesaki Y, et al. Gut-residing segmented filamentous bacteria drive autoimmune arthritis via T helper 17 cells. Immunity. 2010;32:815-27.

24. Vaahtovuo J, Munukka E, Korkeamäki M, Luukkainen R, Toivanen P. Feca microbiota in early rheumatoid arthritis. J Rheumatol. 2008:35:1500-5.

25. Dalvi S, Scher JU, Attur M, Patel J, Abramson SB. Elevated fecal secretory immunoglobulin A, anti-cyclic citrullinated peptide antibodies, and cytokine levels in rheumatoid arthritis patients [abstract 1212]. Arthritis Rheum. 2012:64(10 Suppl):S518

26. Waldman RH, Mach JP, Stella MM, Rowe DS. Secretory IgA in human serum J Immunol. 1970;105:43-7.

27. Brandtzaeg P. Secretory lgA: designed for anti-microbial defense. Front Immunol. 2013;4:222

28. Eijgenraam JW, Oortwijn BD, Kamerling SWA, De Fijter JW, Van Den Wall Bake AWL, Daha MR, et al. Secretory immunoglobulin A (IgA) responses in IgA nephropathy patients after mucosal immunization, as part of a polymeric IgA response. Clin Exp Immunol. 2008;152:227-32.

29. Berglin $E$, Johansson $T$, Sundin $U$, Jidell $E$, Wadell $G$, Hallmans $G$, et al. Radiological outcome in rheumatoid arthritis is predicted by presence of antibodies against cyclic citrullinated peptide before and at disease onset, and by lgA-RF at disease onset. Ann Rheum Dis. 2006;65:453-8.

30. Lindqvist E, Eberhardt K, Bendtzen K, Heinegard D, Saxne T. Prognostic laboratory markers of joint damage in rheumatoid arthritis. Ann Rheum Dis. 2005:64:196-201.

31. Manfredsdottir VF, Vikingsdottir T, Jonsson T, Geirsson AJ, Kjartansson O, Heimisdottir M, et al. The effects of tobacco smoking and rheumatoid factor seropositivity on disease activity and joint damage in early rheumatoid arthritis. Rheumatology (Oxford). 2006;45:734-40.

32. Jorgensen C, Moynier M, Bologna C, Youinou P, Sany J. Rheumatoid factor associated with a secretory component in rheumatoid arthritis. Br J Rheumatol. 1995;34:236-40

33. Hallert E, Husberg M, Kalkan A, Rahmqvist M, Skogh T, Bernfort L. Changes in sociodemographic characteristics at baseline in two Swedish cohorts of patients with early rheumatoid arthritis diagnosed 1996-98 and 2006-09. Scand J Rheumatol. 2015;44:100-5.

34. Arnett FC, Edworthy SM, Bloch DA, McShane DJ, Fries JF, Cooper NS, et al. The American Rheumatism Association 1987 revised criteria for the classification of rheumatoid arthritis. Arthritis Rheum. 1988;31:315-24

35. Prevoo ML, van 't Hof MA, Kuper HH, van Leeuwen MA, van de Putte LB, van Riel PL. Modified disease activity scores that include twenty-eight-joint counts: development and validation in a prospective longitudinal study of patients with rheumatoid arthritis. Arthritis Rheum. 1995:38:44-8.

36. Ekdahl C, Eberhardt K, Andersson SI, Svensson B. Assessing disability in patients with rheumatoid arthritis: use of a Swedish version of the Stanford Health Assessment Questionnaire. Scand J Rheumatol. 1988;17:263-71.

37. Olsson AR, Skogh T, Wingren G. Aetiological factors of importance for the development of rheumatoid arthritis. Scand J Rheumatol. 2004;33:300-6.

38. Larsen A. How to apply Larsen score in evaluating radiographs of rheumatoid arthritis in long-term studies. J Rheumatol. 1995;22:1974-5.

39. Stolt P, Bengtsson C, Nordmark B, Lindblad S, Lundberg I, Klareskog L, et al. Quantification of the influence of cigarette smoking on rheumatoid arthritis: results from a population based case-control study, using incident cases. Ann Rheum Dis. 2003;62:835-41.

40. Svärd A, Kastbom A, Reckner-Olsson A, Skogh T, Presence and utility of IgA-class antibodies to cyclic citrullinated peptides in early rheumatoid arthritis: the Swedish TIRA project. Arthritis Res Ther. 2008;10:R75.

41. Iwasaki K, Okawa-Takatsuji M, Aotsuka S, Ono T. Detection of anti-SS-A/Ro and anti-SS-B/La antibodies of IgA and IgG isotypes in saliva and sera of patients with Sjögren's syndrome. Nihon Rinsho Meneki Gakkai Kaishi. 2003;26:346-54.

42. Sandin C, Eriksson P, Segelmark M, Skogh T, Kastbom A. IgA- and SlgA anti-PR3 antibodies in serum versus organ involvement and disease activity in PR3-ANCA-associated vasculitis. Clin Exp Immunol. 2016;184:208-15.

43. Matysiak-Budnik T, Moura IC, Arcos-Fajardo M, Lebreton C, Ménard S, Candalh C, et al. Secretory IgA mediates retrotranscytosis of intact gliadin peptides via the transferrin receptor in celiac disease. J Exp Med. 2008;205:143-54.

44. Rey J, Garin N, Spertini F, Corthesy B. Targeting of secretory IgA to Peyer's patch dendritic and T cells after transport by intestinal M cells. J Immunol. 2004;172:3026-33.

45. Favre L, Spertini F, Corthesy B. Secretory IgA possesses intrinsic modulatory properties stimulating mucosal and systemic immune responses. J Immunol. 2005;175:2793-800

46. Wendling D, Didier JM, Seilles E. Serum secretory immunoglobulins in ankylosing spondylitis. Clin Rheumatol. 1996;15:590-3. 

PAPER 



\title{
Original article
}

\section{Secretory anti-citrullinated protein antibodies in serum associate with lung involvement in early rheumatoid arthritis}

\author{
Karin Roos Ljungberg ${ }^{1,2}$, Vijay Joshua $\mathbb{1}^{3}$, Thomas Skogh ${ }^{1}$, Anders Eklund ${ }^{4,5}$, \\ C. Magnus Sköld ${ }^{4,5}$, Reza Karimi ${ }^{4,5}$, Sven Nyrén ${ }^{6,7}$, Anna Svärd ${ }^{1,2}$, \\ Anca I. Catrina ${ }^{3}$ and Alf Kastbom ${ }^{1}$
}

\begin{abstract}
Objective. A 'mucosal connection' in RA presently attracts increasing attention. We recently described the occurrence of secretory antibodies to citrullinated protein (SC-ACPA) in sera from patients with recent-onset RA. The current study was performed to evaluate possible associations between serum levels of secretory ACPA and signs of lung involvement in patients with early, untreated RA.

Methods. One hundred and forty-two RA patients were included as part of the 'LUng Investigation in newly diagnosed RA' study. One hundred and six patients were examined with high-resolution CT (HRCT) and 20 patients underwent bronchoscopy, where bronchial biopsies and bronchoalveolar lavage fluid (BALF) samples were obtained. SC-ACPA in serum and BALF were detected by an enzyme-linked immunoassay. Antibody levels were related to smoking history, pulmonary function, HRCT, BALF cell counts and findings in bronchial biopsies.

Results. SC-ACPA occurred in $16 \%$ of the serum samples and in $35 \%$ of the BALF samples. SC-ACPA levels in serum correlated with SC-ACPA levels in BALF $(\sigma=0.50, P=0.027)$ and were higher among patients with HRCT parenchymal lung abnormalities $(P=0.022)$ or bronchiectasis $(P=0.042)$. Also, ever smoking was more frequent among serum SCACPA-positive patients ( $91 \%$ vs $67 \%, P=0.023)$, and the SC-ACPA levels correlated with the number of pack-years $(\sigma=0.20, P=0.020)$.

Conclusion. In early, untreated RA, serum levels of SC-ACPA reflect lung involvement in terms of local ACPA levels, smoking and lung abnormalities on HRCT. These findings strengthen the link between mucosal ACPA responses and the lungs in RA.
\end{abstract}

Key words: rheumatoid arthritis (RA), anti-cyclic citrullinated peptide antibodies (ACPA), mucosal immunity, secretory antibodies

\section{Rheumatology key messages}

- Secretory ACPA was detected in $35 \%$ of RA bronchoalveolar lavage fluid samples.

- Secretory ACPA levels in serum associated with radiographic lung abnormalities and smoking.

- These findings strengthen the link between smoking, mucosal ACPAs and the lungs in RA

\section{Introduction}

Understanding the initiating and triggering steps of RA is crucial for the elaboration of future prevention strategies during the preclinical stages of the disease. The presence of anti-citrullinated peptide/protein antibodies (ACPA) many years before onset of joint symptoms in

${ }^{1}$ Department of Rheumatology and Department of Clinical and Experimental Medicine, Linköping University, Linköping, ${ }^{2}$ Center for Clinical Research Dalarna, Uppsala University, Uppsala,

${ }^{3}$ Rheumatology Unit, Department of Medicine, Karolinska University Hospital and Institutet, ${ }^{4}$ Department of Medicine Solna and Center for Molecular Medicine, Karolinska Institutet, ${ }^{5}$ Department of Respiratory
RA development [1] implies extra-articular locations rather than synovial joints as initial sites of immunization in RA. In recent years, mucosal surfaces have emerged as possible sites for early 'immunologic hits' in RA development, particularly in the subgroup of patients with ACPA [2].

Medicine and Allergy, ${ }^{6}$ Department of Thoracic Radiology, Karolinska University Hospital and ${ }^{7}$ Department of Molecular Medicine and Surgery, Karolinska Institutet, Stockholm, Sweden

Submitted 29 January 2019; accepted 9 June 2019

Correspondence to: Karin Roos Ljungberg, CKF, Nissers väg 3, 79182 Falun, Sweden. E-mail: karin.roosljungberg@Itdalarna.se 
Antibody production at mucosal surfaces mainly involves secretory IgA (SIgA) produced by submucosal plasma cells. SIgA is a dimeric form of IgA which becomes attached to 'secretory component' (SC), during the active process of trans-epithelial antibody transport to the mucosae. Following release into the luminal compartment, SC stabilizes the antibody and protects it from enzymatic degradation [3]. Although SIgA is mainly found in external secretions (e.g. tears, saliva, respiratory lining fluid and gastrointestinal fluid), small amounts can also be detected in human serum [4], including antigen-specific SIgA following mucosal immunization [5]. In addition to IgA, SC may also attach to IgM antibodies, forming secretory $\operatorname{lgM}$. We previously reported the presence of circulating secretory ACPA in RA patients, with a prevalence of $17 \%$ in recent-onset disease [6]. Recently, it was reported that circulating secretory ACPA is mainly of IgM class [7]. Thus, we onwards use the term secretory antibodies to citrullinated protein (SC-ACPA) to describe SCcontaining ACPAs, regardless of isotype and site from which the sample was obtained. Circulating secretory autoantibodies may also be found in other rheumatic diseases; for instance, in ANCA- associated vasculitis, where circulating secretory anti-proteinase 3 (PR3) antibodies were detected in $36 \%$ of the patients [8].

Mucosal immunization to citrullinated proteins in RA patients has been demonstrated not only by the presence of circulating secretory ACPA, but also by ACPA occurrence in saliva [9], sputum [10], bronchoalveolar lavage fluid (BALF) [11] and faeces [12]. Kinslow et al. found increased proportions of circulating IgA plasmablasts among seropositive individuals without apparent joint disease, suggesting that mucosal immune processes are of importance in early stages of disease development [13]. However, the contribution of each mucosal compartment in the initiation and/or propagation of systemic ACPA responses and RA development remains incompletely understood. A number of observations suggest that the mucosal surfaces of the lungs are of particular importance in ACPA- and RA development. The most well-known fact is the epidemiological link between airway irritants (e.g. smoking and silica dust) and ACPA-positive RA [14, 15]. In fact, smoking appears to associate predominately with IgA class ACPA [16]. Another interesting finding in RA is the increased prevalence of inducible bronchus-associated lymphoid tissue containing autoantibody producing plasma cells [17]. Furthermore, identical autoantigens, derived from citrullinated vimentin, were recently identified in bronchial and synovial biopsies from RA patients [18], and lung abnormalities visible on high-resolution CT (HRCT) were found to be overrepresented among seropositive individuals, regardless of arthritis and smoking status $[11,19]$.

Serum analysis of secretory autoantibodies may provide a feasible option to study mucosal immunity in autoimmune diseases. This study aimed to relate SC-ACPA levels in serum to SC-ACPA levels in BALF, and to signs of lung involvement in a cohort of well-characterized patients with early, untreated RA.

\section{Methods}

\section{Patients and controls}

Patients referred from primary care centres because of self-reported joint problems (symptom duration 2-16 months), were asked to participate in the LUng investigation in newly diagnosed RA study at Karolinska University Hospital in Stockholm. The study protocol was approved by the ethics review board in Stockholm, and all patients and controls gave their written consent to participation. The patients had not been treated with glucocorticoids, conventional DMARDs or biologic drugs. The cohort has been described in detail previously [11]. Out of 142 eligible patients, 106 patients underwent HRCT, pulmonary function test and measurement of diffusion capacity for carbon monoxide $\left(\mathrm{DL}_{\mathrm{co}}\right)$. BALF samples and bronchial biopsies were obtained from 20 patients, of which $16(80 \%)$ were ever smokers, and 16 $(80 \%)$ tested positive for IgG-ACPA in serum. The control group to the BALF ACPA analysis comprised 10 patients with sarcoidosis and three healthy controls described previously [20]. Among the BALF controls, eight (62\%) were ever smokers and none tested positive for IgG-ACPA in serum (Table 1).

\section{High-resolution computed tomography}

Within one week after diagnosis, HRCT was performed using a Siemens Sensation CT with $0.625 \mathrm{~mm}$ collimator, $0.5 \mathrm{~s}$ rotation time and pitch $1.120 \mathrm{kV}$ at both full inspiration and expiration. An experienced thoracic radiologist and a pulmonologist reviewed all images in random order, blinded to identity and medical history. Inter observer error was assessed and diverging interpretations were solved thorough consensus. Findings on HRCT were categorized binomial as parenchymal abnormalities (nodules larger than $3 \mathrm{~mm}$, ground-glass opacities, opacities, fibrosis and emphysema) and airway abnormalities (bronchiectasis, air trapping and bronchial wall thickening). Criteria included in the International Classification of HRCT for occupational and environmental respiratory diseases were used to define HRCT abnormalities [21].

\section{BALF and biopsy retrieval}

Sampling procedures have been described in detail previously $[11,22]$. In brief, bronchial mucosal biopsy specimens were taken from the left lung's segmental and sub-segmental septa, whereas BALF was obtained by instillation of five portions of $50 \mathrm{ml}$ of PBS in a middle lobe bronchus. All of the BALF was immediately, gently suctioned back, pooled and no BALF was discarded. Biopsy material and BALF were frozen at $-80^{\circ} \mathrm{C}$ until analysis.

Total number of BALF cells were counted, cell differentials were scored on cytospins stained with May Grunwald Giemsa as previously described [22]. Biopsy specimens were stained with haematoxylin and eosin (H\&E) stain for standard histology and biopsies from RA patients were also evaluated by immunohistochemistry regarding activation-induced cytidine deaminase, $T$ cells (CD3), B cells (CD19), dendritic cells, plasma cells (CD138), 
TABLE 1 Baseline characteristics of study participants

\begin{tabular}{lccc}
\hline \multicolumn{1}{c}{ Baseline characteristics } & $\begin{array}{c}\text { All patients } \\
(\boldsymbol{n}=\mathbf{1 4 2})\end{array}$ & $\begin{array}{c}\text { Patients with available } \\
\text { BALF }(\boldsymbol{n}=\mathbf{2 0})\end{array}$ & $\begin{array}{c}\text { BALF controls } \\
(\boldsymbol{n}=\mathbf{1 3})\end{array}$ \\
\hline Women, $n$ (\%) & $94 / 142(66)$ & $8 / 20(40)$ & $6 / 13(46)$ \\
Age (mean years, range) & $55.0(20-84)$ & $56.0(28-76)$ & $41.2(28-63)$ \\
RF positive, $n$ (\%) & $98 / 141(70)$ & $16 / 20(80)$ & - \\
Serum SC-ACPA positive, $n(\%)$ & $23 / 142(16)$ & $6 / 20(30)$ & - \\
Serum IgA-ACPA positive, $n(\%)$ & $58 / 142(41)$ & $13 / 20(65)$ & $0 / 13(0)$ \\
Serum IgG-ACPA positive, $n(\%)$ & $94 / 142(66)$ & $16 / 20(80)$ & $0 / 13(0)$ \\
BALF SC-ACPA positive, $n(\%)$ & $7 / 20(35)$ & $7 / 20(35)$ & $8 / 13(62)$ \\
Ever smoker, $n$ (\%) & $101 / 142(71)$ & $16 / 20(80)$ & - \\
Current smoker, $n$ (\%) & $42 / 142(30)$ & $9 / 20(45)$ & - \\
Airway abnormality on HRCT, $n(\%)$ & $68 / 106(64)$ & $9 / 19(47)$ & - \\
Parenchymal abnormality on HRCT, $n(\%)$ & $58 / 106(55)$ & $12 / 19(63)$ & - \\
\hline
\end{tabular}

ACPA: anti-citrullinated peptide antibodies; BALF: bronchoalveolar lavage fluid; HRCT: high-resolution CT; SC: secretory component.

macrophages (CD68), peptidyl arginine deaminases (PAD) 2 and 4 , as well as immune cell activation markers (HLADR and HLA-DQ). Immunohistochemistry was evaluated on a four-point scale by blinded semi-quantitative evaluation, where 0 represents absence of staining, 1 low amount of staining, 2 intermediate amount of staining and 3 represents a high amount of specific staining. Results are reported as the median value of two independent observations.

\section{Antibody analyses}

SC-ACPA in serum and BALF were analysed using a modified second generation anti-cyclic citrullinated peptide (CCP2) as antigen (Immunoscan CCPlus, EuroDiagnostica, Malmö, Sweden) [6]. Serum samples were diluted $1: 25$ in kit buffer, whereas BALF samples were analysed undiluted. The detection antibody was a horseradish peroxidase-conjugated polyclonal goat antibody directed to human secretory component (GAHu/SC/ PO, Nordic BioSite, Sweden) diluted in kit buffer, $1: 2000$ for serum and 1:500 for BALF. Incubation and washing were performed according to instructions by the manufacturer. A standard curve was obtained from a serum with a high level of SC-ACPA diluted in a series from $1: 12.5-1: 800$. Absorbance was read by spectrophotometry at $450 \mathrm{~nm}$ (TECAN Sunrise, software: Magellan V7.1; Tecan Nordic AB, Mölndal, Sweden) and optical densities were recalculated into arbitrary units $(A U)$ by relating to the standard curve. All samples were analysed in duplicate and presented as mean values. Inter-assay coefficient of variation was $8 \%$ and intra-assay coefficient of variation was $5 \%$. IgA-ACPA was analysed by a fluoroenzyme immunoassay with CCP2 as antigen on a PhaDia 250 instrument (EliA, ThermoFisher AB, Uppsala, Sweden) [16]. IgG-ACPA was analysed with a commercial anti-cyclic citrullinated peptide 2 (anti-CCP2) kit (Immunoscan CCPlus, EuroDiagnostica, Malmö, Sweden).

Cut-off limits for serum SC- and IgA-ACPA were set to the 99th percentile of 101 blood donors (SC-ACPA
$153 \mathrm{AU} / \mathrm{ml}$ and IgA-ACPA $2 \mu \mathrm{g} / \mathrm{ll}$ ) as previously described $[6,16]$. The cut-off limit for BALF SC-ACPA was set to $138 \mathrm{AU} / \mathrm{ml}$, based on three standard deviations among the 13 control BALF samples.

\section{Statistics}

Mann-Whitney $U$ test was used to compare SC-ACPApositive and negative patients regarding levels of other antibody isotypes, inflammation markers, immunohistochemistry scores, BALF cell counts, pulmonary function test results, HRCT findings and cigarette pack years. Categorical data were tested by Fisher's exact test. Correlations to different ACPA isotypes and inflammatory markers, as well as number of swollen/tender joints were analysed by using Spearman's correlation. Linear regression analysis was used to evaluate the association between SC-ACPA and number of pack years adjusted for age. Multivariable logistic regression analysis was performed to evaluate associations between lung changes visible on HRCT and SC-ACPA adjusted for age, sex and smoking status. Logarithmic values of SC-ACPA were used in the regression analysis. Two-sided $P$ values $<0.05$ were considered statistically significant. Statistical analyses were performed with SPSS v.23.

\section{Results}

\section{ACPA isotypes in serum and BALF}

Baseline characteristics are shown in Table 1. SC-ACPA tests were positive in 23 of 142 serum samples (16\%), 58 (41\%) tested positive for IgA-ACPA, and 94 (66\%) for IgGACPA. All patients positive for serum SC-ACPA also had positive serum IgG-ACPA tests, while serum IgA-ACPA co-occurred in $91 \%$. The BALF SC-ACPA test was positive in 7 out of 20 patients (35\%). Among these, four patients $(57 \%)$ also tested positive for serum SC-ACPA, and all tested positive regarding serum IgA- and IgG-ACPA.

As shown in Table 2, BALF SC-ACPA levels were significantly correlated to IgA-ACPA and IgG-ACPA in both 
TABLE 2 Spearman's correlation coefficients $(\sigma)$ between antibody levels and disease activity measures

\begin{tabular}{|c|c|c|c|c|}
\hline \multirow{2}{*}{ Correlations } & \multicolumn{2}{|c|}{ BALF SC-ACPA $(n=20)$} & \multicolumn{2}{|c|}{ Serum SC-ACPA $(n=142)$} \\
\hline & $\sigma$ & p-value & $\sigma$ & $P$-value \\
\hline Serum SC-ACPA & 0.50 & 0.027 & - & - \\
\hline Serum IgA-ACPA & 0.75 & $<0.001$ & 0.70 & $<0.001$ \\
\hline Serum IgG-ACPA & 0.55 & 0.012 & 0.78 & $<0.001$ \\
\hline BALF SC-ACPA & - & - & 0.50 & 0.027 \\
\hline BALF IgA-ACPA & 0.85 & $<0.001$ & 0.67 & 0.003 \\
\hline BALF IgG-ACPA & 0.70 & 0.001 & 0.73 & 0.001 \\
\hline ESR & 0.01 & n.s. & 0.17 & 0.047 \\
\hline CRP & 0.45 & 0.047 & 0.12 & n.s. \\
\hline SJC & 0.10 & n.s. & -0.11 & n.s. \\
\hline TJC & -0.10 & n.s. & -0.06 & n.s. \\
\hline DAS28 & -0.09 & n.s. & 0.07 & n.s. \\
\hline
\end{tabular}

ACPA: anti-citrullinated peptide antibodies; BALF: bronchoalveolar lavage fluid; DAS28: 28-joint disease activity score; n.s.: not significant; SC: secretory component; SJC: swollen joint count; TJC: tender joint count.

BALF and serum. Serum SC-ACPA correlated significantly with ACPA levels in serum and BALF regarding all tested ACPA isotypes (Table 2).

\section{SC-ACPA and disease activity}

BALF SC-ACPA correlated significantly with CRP $(\sigma=0.45$, $P=0.047)$ but not with any other marker of disease activity. Serum levels of SC-ACPA correlated significantly with $\operatorname{ESR}(\sigma=0.17, P=0.047)$, but not with any other marker of disease activity (Table 2). BALF SC-ACPA-positive patients had significantly higher levels of CRP (median 14 vs $4.0 \mathrm{mg} / \mathrm{l}, P=0.034$ ) at inclusion in the cohort.

\section{SC-ACPA and smoking}

In the whole RA cohort, 101 (71\%) participants were ever smokers and $42(30 \%)$ were current smokers. The corresponding numbers in the subgroup of patients undergoing bronchoscopy and BALF sampling $(n=20)$ were $16(80 \%)$ and $9(45 \%)$ respectively. Ever smoking was more frequent among serum SC-ACPA-positive patients ( $91 \%$ vs $67 \%, P=0.023$ ) (Fig. 1a), which was also reflected by a greater number of cigarette pack-years among serum SCACPA-positive patients compared with serum SC-ACPAnegative patients (median 16 vs 7.8 pack-years, $P=$ 0.035). Serum levels of SC-ACPA correlated significantly with the number of pack-years $(\sigma=0.20, P=0.02)$ and remained associated after adjustment for age $(P=0.03)$. Levels of SC- and IgA-ACPA in serum were higher among ever smokers compared with never smokers (median 20 vs $7.9 \mathrm{AU} / \mathrm{ml}, P=0.015$; and 1.6 vs $0.8 \mu \mathrm{g} / \mathrm{l}, P=0.034$ ), but not for IgG-ACPA $(P=0.44)$ (Fig. $1 b)$. The same results were seen regarding current smokers, who had higher levels of SC- and IgA-ACPA in serum compared with former smokers (median $53 \mathrm{vs} 7.9 \mathrm{AU} / \mathrm{ml}, P=0.002$ and median 2.7 vs $1.1 \mu \mathrm{g} / \mathrm{l}, P=0.002$ ). Levels or status regarding SC-ACPA in BALF did not significantly differ according to smoking status (median level 110 vs $26 \mathrm{AU} / \mathrm{ml}, P=0.24$; proportion ever smokers in BALF SC-ACPA positive $86 \%$ vs negative $77 \%, P=1$ ).

SC-ACPA in relation to lung function, histology and radiographic appearance

Airway abnormalities were detected in 68 of 106 patients $(64 \%)$ and parenchymal abnormalities in 58 of 106 (55\%). Distribution of airway and parenchymal abnormalities according to serum SC-ACPA and IgA-ACPA positivity is given in Supplementary Table S1, available at Rheumatology online. No significant association between antibody status and HRCT abnormalities were observed (Supplementary Table S1, available at Rheumatology online.). However, serum levels of SCACPA were significantly higher among patients with any parenchymal HRCT abnormality compared with those without (median 35 vs $7.9 \mathrm{AU} / \mathrm{ml}, P=0.022$ ) (Fig. 2a). This remained significant also after adjustments for age, sex and smoking (odds ratio (OR) 1.4, 95\% Cl 1.03-1.93, $P=0.034)$. No statistically significant differences were observed when individual parenchymal abnormalities were analysed separately (emphysema $P=0.11$, fibrosis $P=0.19$, ground-glass opacities $P=0.65$, opacities $P=$ 0.16 and nodules $>3 \mathrm{~mm} P=0.67$; Fig. 2a). Similar to SCACPA, serum IgA-ACPA levels were raised among patients with any parenchymal abnormalities (median 1.9 vs $1.0 \mu \mathrm{g} / \mathrm{l}, P=0.04$ ), while no significant difference was seen regarding IgG-ACPA $(P=0.088)$. Patients with bronchiectasis on HRCT had higher levels of SC-ACPA in serum compared with those without bronchiectasis (median 44 vs $7.9 \mathrm{AU} / \mathrm{ml}, P=0.042$ ), while no significant difference was detected regarding IgA- or IgG-ACPA levels. The association between SC-ACPA and bronchiectasis remained significant after adjustment for age, sex and smoking (OR 1.6, 95\% Cl 1.06-2.39, $P=0.026$ ). No significant difference was observed regarding presence of wall thickening $(P=0.45)$, air trapping $(P=0.62)$, or airway abnormalities grouped together $(P=0.15)$ (Fig. 2b). BALF 
FIG. 1 Smoking and different anti-citrullinated protein antibody isotypes in serum

(a)

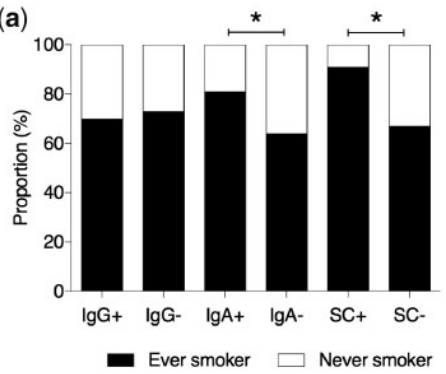

(b)

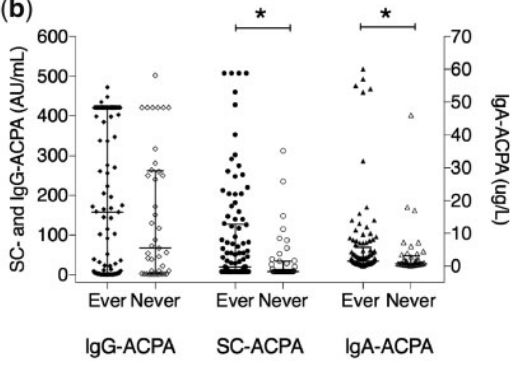

Smoking habits in relation to status (a) and levels (b) of different anti-citrullinated protein antibody (ACPA) isotypes in serum. ${ }^{*}=P<0.05$.

FIG. 2 Secretory component-containing anti-citrullinated protein antibodies in relation to lung abnormalities on HRCT

(a)

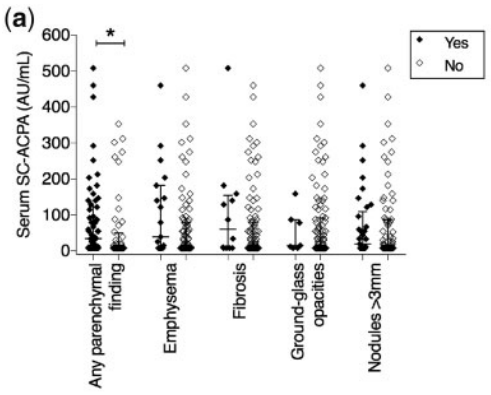

(c)

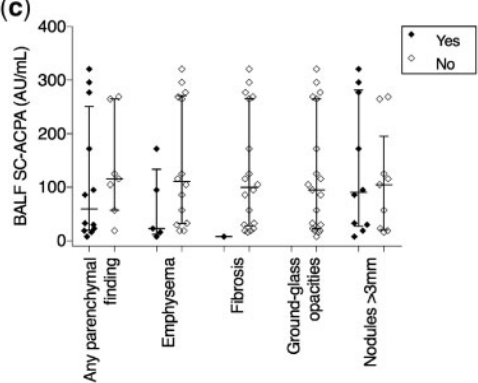

(b)

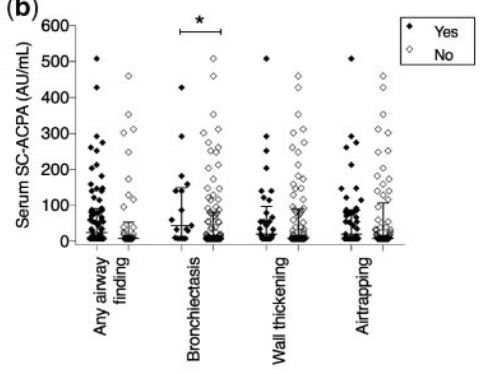

(d)

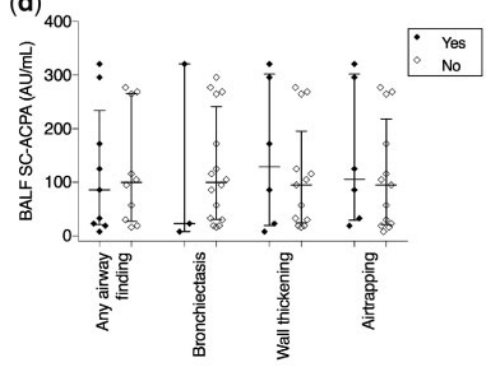

Levels of serum secretory component-containing anti-citrullinated protein antibodies (SC-ACPA) in relation to parenchymal (a) and airway (b) findings on HRCT, and levels of BALF SC-ACPA in relation to parenchymal (c) and airway (d) HRCT findings. ${ }^{*}=P<0.05$. HRCT: high-resolution CT; BALF: bronchoalveolar lavage fluid.

SC-ACPA was not significantly associated with HRCT abnormalities (Fig. 2c and d).

Comparing serum SC-ACPA negative and positive patients did not reveal any significant differences regarding carbon monoxide diffusing capacity $\left(\mathrm{DL}_{\mathrm{co}}\right)(77 \%$ vs $79 \%$, $P=0.14)$, forced expiratory volume in $1 \mathrm{~s}\left(\mathrm{FEV}_{1}\right)(97 \%$ vs $100 \%, P=0.39$ ), or $\mathrm{FEV}_{1} /$ forced vital capacity (FEV $_{1} / \mathrm{FVC}$ ) (76\% vs $73 \%, P=0.065)$. No significant differences in 
pulmonary function tests were found regarding BALF SCACPA or serum IgA-ACPA (data not shown).

BALF cell concentrations, both relative and quantitative, of macrophages, lymphocytes, neutrophils, eosinophils and basophils, did not significantly differ according to serum or BALF SC-ACPA or serum IgA-ACPA status (Supplementary Table S2, available at Rheumatology online.).

In bronchial mucosal biopsies, patients with SC-ACPA in BALF had higher expression of immune activation marker HLA-DQ compared with patients testing negative (median 3.0 (range 2-3) vs 1.5 (range $0-3$ ), $P=0.021$ ) (Supplementary Fig. S1, available at Rheumatology online). In contrast, patients with serum SC-ACPA had significantly lower scores regarding PAD4 (median 1.0 (range $0-2)$ vs 2.0 (range $1-3$ ), $P=0.033$ ) and macrophages (CD68) (median 0.0 (range 0-1) vs 1.0 (range $0-3$ ), $P=$ 0.022) compared with serum SC-ACPA-negative patients (Supplementary Fig. S1, available at Rheumatology online). The other markers did not show significant differences (Supplementary Fig. S2, available at Rheumatology online).

Lymphocyte infiltrates were visible in $57 \%$ of the BALF SC-ACPA-positive patients as compared with $38 \%$ among BALF SC-ACPA-negative patients $(P=0.64)$. Regarding serum SC-ACPA status, the corresponding numbers were $33 \%$ vs $50 \%(P=0.64)$.

\section{Discussion}

In this study of early untreated RA patients, we found that levels of circulating secretory ACPA associated with ACPA levels of all isotypes in BALF, with smoking and lung parenchymal abnormalities and/or airway changes on HRCT. Previous studies have shown that circulating IgA- and SC-ACPA are both associated with smoking, while IgG-ACPA is not $[6,16]$. The current study extends these previous findings by linking circulating IgA- and SCACPAs not only to smoking, but also to mucosal IgA- and SC-ACPA levels in the lungs, and to HRCT findings. Also, the mere presence of SC-ACPA in BALF strengthens the hypothesis of local ACPA production in the lungs, as secretory antibodies assemble during active trans-epithelial transport. The moderate correlation between serum and BALF levels implies that circulating SC-ACPA may originate from other mucosal compartments as well, and the oral cavity and gastrointestinal tract should be addressed in this context. Although SC-ACPA in serum has the possible advantage of reflecting several mucosal surfaces in one sample, the contribution of each mucosal compartment needs to be elucidated.

The prevalence of SC-ACPA in serum in the present study (16\%) was very similar to previous findings [6]. The BALF SC-ACPA frequency $(35 \%)$ is reported here for the first time. It is higher in the BALF as compared with serum, as expected [4], but lower compared with serum IgG-ACPA (66\%). This could be explained by patient-specific involvement of other mucosal sites than the lungs and the mucosal imprinting fading away as systemic autoimmunity and disease develop. Also, modest but significant correlations between SC-ACPA and inflammatory markers were replicated in the current study, revealing a correlation between serum SC-ACPA and ESR, and higher levels of CRP in BALF SC-ACPA-positive patients. As swollen and tender joint counts do not correlate with SC-ACPA, it remains a possibility that the positive correlation between SC-ACPA and inflammatory markers instead reflects mucosal inflammation and/or possibly an attempt to down-regulate systemic inflammation.

Smoking is a well-known risk factor for developing RA, and patients who continue to smoke after diagnosis have a more active disease [23]. In this study, we found robust associations between smoking, both in terms of status and pack-years, and serum SC- and IgA-ACPA. The connection between smoking and mucosa-related ACPAs may have several explanations; for instance, by increased local peptidyl arginine expression and citrullination [14, 24]. It is also conceivable that chronic irritation and nonspecific local inflammation induced by smoking could disrupt the mucosal lining and thereby facilitate translocation of secretory ACPA to the systemic circulation. Among patients with chronic obstructive pulmonary disease, more citrullination was observed in lung tissue samples as compared with non-chronic obstructive pulmonary disease patients and, importantly, this was more related to inflammation than to smoking $[25,26]$. Thus, both cigarette smoking and inflammatory states not caused by smoking may initiate citrullination and ACPA formation in predisposed individuals.

Upon histological examination of bronchial biopsies, it was previously reported that IgG-ACPA-positive RA patients had more lymphocyte infiltration compared with ACPA-negative patients [22]. In the current study, i.e. within the same patient cohort, we found that this was not the case for patients testing positive for serum SCor IgA-ACPA. On the other hand, we found that patients with SC-ACPA in BALF displayed increased expression of HLA-DQ indicating a more pronounced local immune activation. Rather surprisingly, serum SC-ACPA was associated with lower macrophage content and PAD4 expression in bronchial biopsies. Macrophages are potent PAD4 producers [27], and therefore, the lower expression of PAD4 could be related to the lower macrophage count. We could not detect any differences regarding macrophage content in BALF.

We have previously reported an enrichment of HRCT abnormalities in early RA as compared with age, sex and smoking-matched controls that correlates with presence of IgG-ACPA [11]. In line with this, ACPA-positive patients who do not experience any symptoms of joint inflammation may have visible signs of bronchial wall thickening, bronchiectasis, centrilobular opacities and air trapping [19]. In the present study, patients with parenchymal abnormalities on HRCT had higher levels of serum SC- and IgA-ACPA compared with patients with normal HRCTs. Similar findings were made regarding bronchiectasis. Perry and co-workers showed that in established $\mathrm{RA}$, bronchiectasis associated not only with a more severe rheumatic disease, but also with higher levels of IgG-ACPA and RF [28]. Also, interstitial lung disease in RA 
(RA-ILD) associated with higher ACPA levels and a broader ACPA repertoire, compared with patients not suffering from RA-ILD, while antibodies to non-citrullinated proteins were similar [29]. Given these findings, we find it less likely that the association between serum SC-ACPA levels and HRCT abnormalities merely reflects an increased ability for secretory antibodies to relocate from the lung to the circulation among patients with such pathological changes of the lung tissue. Instead, it may indicate that mucosa-associated antibody formation and development of structural lung changes may share underlying pathological processes.

Strengths of the current study include the extensive pulmonary characterization of patients, the short duration of symptoms/disease, and the absence of interfering antirheumatic therapy. A limitation is the rather small number of RA patients with available biopsies and BALF samples.

In conclusion, SC-ACPA can be detected in BALF and correlates with ACPA levels in the circulation. SC-ACPA levels in serum associate with cigarette smoking and parenchymal abnormalities and/or airway changes on HRCT. Taken together, these findings strengthen the link between smoking, mucosal ACPA responses and lung involvement in RA.

\section{Acknowledgements}

A.I.C. received grants from King Oscar II Jubilee Foundation, the Konung Gustaf V: s och Drottning Victorias Frimurarestiftelse, FOREUM Foundation for Research in Rheumatology, ERC (grant agreement CoG 2017 - 7722209_PREVENT RA) and the EU/EFPIA IMI funded project RTCure (grant agreement 777357_RTCu re). A.K. received grants from King Gustaf V's 80-year Foundation (grant number FAl-2017- 0420) and the Swedish Rheumatism Association (grant number R754141). We thank the Immunology Clinic at Linköping University hospital for serum IgA-ACPA analyses. K.R.L. performed the antibody analyses regarding SC-ACPA in serum and BALF. K.R.L., V.J., and A.S. performed the statistical analysis. A.I.C., A.K. and T.S. conceived and designed the study. C.M.S. and A.E. included patients, performed bronchoscopies, interpreted and analysed data and contributed to acquisition of data. R.K. and S.N. designed the reading protocol and performed the reading of the HRCT. All authors were involved in the writing process of the manuscript, drafting or critically revising, and all authors approved the final version to be published.

Funding: This work was supported by grants from Center for Clinical Research Dalarna, the Swedish Heart Lung Foundation, and through the Regional Agreement on Medical Training and Clinical Research (ALF) between Stockholm County Council and Karolinska Institutet.

Disclosure statement: The authors have declared no conflicts of interest.

\section{Supplementary data}

Supplementary data are available at Rheumatology online.

\section{References}

1 Kokkonen $\mathrm{H}$, Mullazehi M, Berglin E et al. Antibodies of $\operatorname{lgG}, \lg A$ and IgM isotypes against cyclic citrullinated peptide precede the development of rheumatoid arthritis. Arthritis Res Ther 2011;13:R13.

2 Catrina Al, Deane KD, Scher JU. Gene, environment, microbiome and mucosal immune tolerance in rheumatoid arthritis. Rheumatology 2016;55:391-402.

3 Brandtzaeg P. Secretory IgA: designed for anti-microbial defense. Front Immunol 2013;4:222.

4 Waldman RH, Mach JP, Stella MM, Rowe DS. Secretory IgA in human serum. J Immunol 1970;105:43-7.

5 Eijgenraam JW, Oortwijn BD, Kamerling SWA et al. Secretory immunoglobulin A ( $\lg A)$ responses in $\lg A$ nephropathy patients after mucosal immunization, as part of a polymeric IgA response. Clin Exp Immunol 2008;152:227-32.

6 Roos K, Martinsson K, Ziegelasch M et al. Circulating secretory IgA antibodies against cyclic citrullinated peptides in early rheumatoid arthritis associate with inflammatory activity and smoking. Arthritis Res Ther 2016;18:119.

7 van Delft MAM, van der Woude D, Toes REM, Trouw LA. Secretory form of rheumatoid arthritis-associated autoantibodies in serum are mainly of the IgM isotype, suggesting a continuous reactivation of autoantibody responses at mucosal surfaces. Ann Rheum Dis 2019;78:146-8.

8 Sandin C, Eriksson P, Segelmark M, Skogh T, Kastbom A. IgA- and SIgA anti-PR3 antibodies in serum versus organ involvement and disease activity in PR3-ANCA-associated vasculitis. Clin Exp Immunol 2016;184:208-15.

9 Svard A, Kastbom A, Sommarin Y, Skogh T. Salivary IgA antibodies to cyclic citrullinated peptides (CCP) in rheumatoid arthritis. Immunobiology 2013;218:232-7.

10 Willis VC, Demoruelle MK, Derber LA et al. Sputum autoantibodies in patients with established rheumatoid arthritis and subjects at risk of future clinically apparent disease. Arthritis Rheum 2013;65:2545-54.

11 Reynisdottir G, Karimi R, Joshua V et al. Structural changes and antibody enrichment in the lungs are early features of anti-citrullinated protein antibody-positive rheumatoid arthritis. Arthritis Rheumatol 2014;66:31-9.

12 Dalvi S, Scher JU, Attur M, Patel J, Abramson SB. Elevated fecal secretory immunoglobulin $A$, anti-cyclic citrullinated peptide antibodies, and cytokine levels in rheumatoid arthritis patients [abstract 1212]. Arthritis Rheum 2012;64:S518.

13 Kinslow JD, Blum LK, Deane KD et al. Elevated IgA plasmablast levels in subjects at risk of developing rheumatoid arthritis. Arthritis Rheumatol 2016;68:2372-82.

14 Klareskog L, Stolt P, Lundberg K et al. A new model for an etiology of rheumatoid arthritis: smoking may trigger HLADR (shared epitope)-restricted immune reactions to autoantigens modified by citrullination. Arthritis Rheum 2006;54:38-46. 
15 Stolt P, Yahya A, Bengtsson $\mathrm{C}$ et al. Silica exposure among male current smokers is associated with a high risk of developing ACPA-positive rheumatoid arthritis. Ann Rheum Dis 2010;69:1072-6.

16 Svard A, Skogh T, Alfredsson L et al. Associations with smoking and shared epitope differ between IgA- and IgGclass antibodies to cyclic citrullinated peptides in early rheumatoid arthritis. Arthritis Rheumatol 2015;67:2032-7.

17 Rangel-Moreno J, Hartson L, Navarro C et al. Inducible bronchus-associated lymphoid tissue (BALT) in patients with pulmonary complications of rheumatoid arthritis. $\mathrm{J}$ Clin Invest 2006;116:3183-94.

18 Ytterberg AJ, Joshua V, Reynisdottir G et al. Shared immunological targets in the lungs and joints of patients with rheumatoid arthritis: identification and validation. Ann Rheum Dis 2015;74:1772-7.

19 Demoruelle MK, Weisman MH, Simonian PL et al. Brief report: airways abnormalities and rheumatoid arthritisrelated autoantibodies in subjects without arthritis: early injury or initiating site of autoimmunity? Arthritis Rheum 2012;64:1756-61.

20 Scher JU, Joshua V, Artacho A et al. The lung microbiota in early rheumatoid arthritis and autoimmunity. Microbiome 2016;4:60

21 Kuska Y, Hering KG, Parker JE. International classification of HRCT for occupational and enviromental respiratory diseases. Tokyo: Springer-Verlag, 2005.

22 Reynisdottir G, Olsen H, Joshua V et al. Signs of immune activation and local inflammation are present in the bronchial tissue of patients with untreated early rheumatoid arthritis. Ann Rheum Dis 2016;75:1722-7.

23 Manfredsdottir VF, Vikingsdottir T, Jonsson T et al. The effects of tobacco smoking and rheumatoid factor seropositivity on disease activity and joint damage in early rheumatoid arthritis. Rheumatology 2006;45:734-40.

24 Makrygiannakis D, Hermansson M, Ulfgren AK et al. Smoking increases peptidylarginine deiminase 2 enzyme expression in human lungs and increases citrullination in BAL cells. Ann Rheum Dis 2008;67:1488-92.

25 Lugli EB, Correia RE, Fischer R et al. Expression of citrulline and homocitrulline residues in the lungs of nonsmokers and smokers: implications for autoimmunity in rheumatoid arthritis. Arthritis Res Ther 2015;17:9.

26 Ruiz-Esquide V, Gomara MJ, Peinado VI et al. Anti-citrullinated peptide antibodies in the serum of heavy smokers without rheumatoid arthritis. A differential effect of chronic obstructive pulmonary disease? Clin Rheumatol 2012;31:1047-50.

27 Wang S, Wang Y. Peptidylarginine deiminases in citrullination, gene regulation, health and pathogenesis. Biochim Biophys Acta 2013;1829:1126-35.

28 Perry E, Eggleton P, De Soyza A, Hutchinson D, Kelly C Increased disease activity, severity and autoantibody positivity in rheumatoid arthritis patients with co-existent bronchiectasis. Int J Rheum Dis 2017;20:2003-11.

29 Giles JT, Danoff SK, Sokolove J et al. Association of fine specificity and repertoire expansion of anticitrullinated peptide antibodies with rheumatoid arthritis associated interstitial lung disease. Ann Rheum Dis 2014;73:1487-94. 
PAPER 



\title{
Presence of salivary lgA anti-citrullinated protein antibodies associate with higher disease activity in patients with rheumatoid arthritis
}

\author{
Karin Roos Ljungberg ${ }^{1,2^{*}}$, Emil Börjesson ${ }^{1}$, Klara Martinsson ${ }^{1}$, Jonas Wetterö ${ }^{1}$, Alf Kastbom ${ }^{1,3}$ and Anna Svärd ${ }^{1,2}$
}

\begin{abstract}
Background: Circulating IgA anti-citrullinated protein antibodies (ACPA) associate with more active disease, but a previous study implied that salivary IgA ACPA is related to a less severe disease. Therefore, we aimed to characterize the IgA ACPA response in the saliva and serum in relation to clinical picture and risk factors among patients with rheumatoid arthritis (RA).

Methods: RA patients $(n=196)$ and healthy blood donors $(n=101)$, included in the cross-sectional study "Secretory ACPA in Rheumatoid Arthritis" (SARA), were analyzed for ACPA of IgA isotype, and for subclasses IgA1 and IgA2 ACPA in paired saliva and serum samples using modified enzyme-linked immunosorbent assays (ELISA) targeting reactivity to a cyclic citrullinated peptide (anti-CCP). Cutoff levels for positive tests were set at the 99th percentile for blood donors. Antibody levels were related to clinical characteristics, radiographic damage, smoking habits, and carriage of HLA-DRB1/shared epitope (SE).

Results: IgA ACPA in the saliva was found in $12 \%$ of RA patients, IgA1 occurred in 10\%, and IgA2 in 9\%. In serum, IgA ACPA was found in 45\% of the patients, IgA1 in 44\%, and IgA2 in 39\%. Levels of IgA ACPA in the saliva correlated significantly with serum levels of IgA $(r=0.455)$. The presence of salivary IgA ACPA was associated with a higher erythrocyte sedimentation rate (ESR), 28-joint disease activity score, tender joint count, and patient global assessment at the time of sampling. None of the antibodies was associated with smoking, SE, or radiographic damage.

Conclusion: Salivary IgA ACPAs were detected in a subset of RA patients in association with higher disease activity. This suggests that mucosal ACPA responses in the oral cavity may contribute to disease-promoting processes in RA

Keywords: Rheumatoid arthritis, Anti-citrullinated protein antibodies (ACPA), Mucosal immunity, Immunoglobulin A (IgA), IgA subclasses, Saliva
\end{abstract}

\footnotetext{
* Correspondence: karin.roos@liu.se

'Division of Inflammation and Infection, Department of Biomedical and

Clinical Sciences, Linköping University, Linköping, Sweden

${ }^{2}$ Center for Clinical Research Dalarna, Uppsala University, Uppsala, Sweden

Full list of author information is available at the end of the article
}

(c) The Author(s). 2020 Open Access This article is licensed under a Creative Commons Attribution 4.0 International License, which permits use, sharing, adaptation, distribution and reproduction in any medium or format, as long as you give appropriate credit to the original author(s) and the source, provide a link to the Creative Commons licence, and indicate if changes were made. The images or other third party material in this article are included in the article's Creative Commons licence, unless indicated otherwise in a credit line to the material. If material is not included in the article's Creative Commons licence and your intended use is not permitted by statutory regulation or exceeds the permitted use, you will need to obtain permission directly from the copyright holder. To view a copy of this licence, visit http://creativecommons.org/licenses/by/4.0/ The Creative Commons Public Domain Dedication waiver (http://creativecommons.org/publicdomain/zero/1.0/) applies to the data made available in this article, unless otherwise stated in a credit line to the data. 


\section{Introduction}

Mucosal surfaces, rather than the joints, are proposed as sites of initial triggering events in rheumatoid arthritis (RA) development, particularly in anti-citrulline protein antibody (ACPA)-positive disease [1, 2]. ACPA can be detected in serum years before the onset of arthritis [3, 4], which implies that the autoimmune reaction starts years before the joints become involved. In clinical practice, IgG ACPA is often analyzed, but ACPA exists in several isotypes including $\operatorname{IgA}$, and the latter has been identified in several mucosal fluids including saliva $[5,6]$.

IgA antibodies play important roles at mucosal surfaces, capable of both pro- and anti-inflammatory effects, e.g., opsonizing pathogens, neutralizing toxins, and inhibiting microbial adhesion to epithelia $[7,8]$. IgA exists in two subclasses, IgA1 and IgA2, with different distributions in serum and mucosal fluids [9]. In serum, IgA1 dominates with a proportion of IgA1:IgA2 of 9:1, and in other secretions, the proportion is variable with higher proportions of IgA2 $[9,10]$. Elevated relative amounts of IgA2 have been reported in colostrum, tears, nasal fluid, saliva, and intestinal lavage fluid [11-13].

In serum, monomeric IgA dominates, whereas in secretions, IgA is mainly dimeric. Dimeric IgA is produced by subepithelial plasma cells, and during the transepithelial transportation into the lumen, a protein chain, the secretory component (SC), is attached to form secretory IgA (SIgA) [8-10]. SIgA is mainly found in mucosal secretions, but may also be detected in small amounts in the circulation [14]. Several studies have highlighted local ACPA production at mucosal surfaces, possibly suggesting involvement in RA pathogenesis [6, 15-18]. We have identified circulating SC-containing ACPA (SC ACPA), which is associated with smoking and high inflammatory activity in early RA [18]. Whether or not levels of SC ACPA in the circulation reflect ACPA production in the oral cavity remains unknown.

Circulating IgA ACPA is found in $30-50 \%$ of RA patients and has been shown to associate with cigarette smoking as well as a more severe disease $[5,19,20]$. In contrast to IgG ACPA, IgA ACPA is not associated with the RA risk gene HLA-DRB1 shared epitope (SE) [20]. A possible inducer of ACPA production in RA is periodontal bacteria such as Porphyromonas gingivalis ( $P$. gingivalis) which has the ability to citrullinate peptides in the oral cavity [2]. Antibodies to P. gingivalis have been demonstrated to associate with ACPA in RA patients [21], and oral priming by $P$. gingivalis has been shown to induce arthritis in rats [22]. IgA subclasses of rheumatoid factor (RF) have been investigated in sera and different mucosal secretions [23], where RF in serum and synovial fluid was found to be mainly of IgA1 subclass, whereas RF of IgA2 subclass was more prevalent in the saliva. In a previous pilot study, we reported the occurrence of IgA ACPA in the saliva in $22 \%$ of patients with RA, associating with less joint erosions [6].

In this study, we aimed to investigate salivary and circulating IgA ACPA antibodies, including subclasses, in relation to disease characteristics and risk factors in RA patients.

\section{Methods}

\section{Study subjects and samples}

One hundred ninety-six patients with established RA from the County of Dalarna, Sweden, were included in the cross-sectional, observational, "Secretory antibodies in Rheumatoid Arthritis" (SARA) study with enrolment 2012-2013. RA patients were randomly selected among planned follow-up visits at the Rheumatology Clinic, Falun Hospital, Sweden. Healthy blood donors $(n=101)$ were recruited as controls from the local blood donor center and referred to the Rheumatology Clinic for blood and saliva sampling. The ethics review board in Uppsala, Sweden, approved of the study, and all participants signed a written informed consent (Uppsala: 211/ 159). Participants were required to provide at least 0.5 $\mathrm{mL}$ of the saliva during the 10-min sampling time; otherwise, they were excluded from the study.

Paired saliva and serum samples were collected at the same visit at the Rheumatology Clinic. Participants were asked to restrain from eating, drinking other liquids than water, brushing teeth, or smoking $1 \mathrm{~h}$ before saliva sampling. Passive secretion was used for saliva sampling, i.e., the study participant leaned forward and drooled $10 \mathrm{~min}$ into a test tube placed on ice. After the disruption of mucus fibers by pipetting a few times, the saliva samples were centrifuged for $5 \mathrm{~min}$ at $5000 \mathrm{~g}$. Serum samples were centrifuged $5 \mathrm{~min}$ at $5000 \mathrm{~g}$. Serum and saliva samples were stored at $-80^{\circ} \mathrm{C}$ until further analyses.

\section{Antibody analyses}

Commercially available serum IgG-class anti-cyclic citrullinated peptide (anti-CCP) enzyme-linked immunoassays (ELISA) tests (CCPlus ${ }^{\circ}$ Immunoscan, Euro Diagnostica AB, Malmö, Sweden) were modified to analyze IgA, IgA1, and IgA2 ACPA in the saliva and serum, as well as for serum SC and IgG ACPA. All samples were analyzed in duplicate, and reanalysis was carried out if the coefficient of variation between the duplicate samples was $>20 \%$. The cutoff levels for a positive test of saliva ACPA (IgA, IgA1, and IgA2) were set at the 99th percentile among saliva samples from blood donors, and cutoff levels for serum ACPA (IgA, IgA1, IgA2, and SC) were set at the 99th percentile in serum among blood donors. 


\section{Antibody analyses in the saliva}

The saliva was thawed at room temperature and centrifuged $\left(15,000 \mathrm{~g}\right.$ at $4{ }^{\circ} \mathrm{C}$ for $\left.10 \mathrm{~min}\right)$ to remove non-soluble material. The supernatant was diluted to a final concentration of 1:20. The secondary antibody in the salivary IgA ACPA assay (Polyclonal Rabbit Anti-Human IgA/ HRP, DakoCytomation, Glostrup-Denmark) was diluted 1:200. Secondary antibodies for the subclass analyses (IgA1 antibody No. ABIN135642 and for IgA2 ABIN135642, Antibodies online, Aachen, Germany) were diluted 1:300. Incubation and washing were carried out according to the manufacturer's instructions. Absorbance was read at $450 \mathrm{~nm}$ (Multiscan RC MOD 351, Labsystems, Helsinki, Finland).

To adjust for non-specific IgA adsorption, all samples were tested against a negative control peptide (cyclic arginine peptide, $\mathrm{CAP}$, Euro Diagnostica $\mathrm{AB}$ ). Anti-CCP and anti-CAP analyses were performed in parallel. AntiCAP background levels were subtracted from anti-CCP values (delta optical density (OD)-measurements for anti-CCP and anti-CAP), and the cutoff values for a positive test were set to 0.78 for IgA ACPA, 0.70 for IgA1 ACPA, and 0.39 for IgA2 ACPA, corresponding to the 99th percentile of the 101 healthy blood donors.

Total IgA in the saliva was analyzed with enzyme immunoassay tests from the IBL International (IgA Saliva ELISA, IBL International, Hamburg, Germany).

\section{Antibody analyses in the serum}

Serum samples were analyzed for IgG ACPA according to the manufacturer's instruction (Euro Diagnostica $A B$ ), with cutoff set at $25 \mathrm{U} / \mathrm{mL}$. Serum IgA and SC ACPA analyses were performed as previously described [5, 18]. In brief, for SC ACPA analyses, serum was diluted 1:25 and for IgA ACPA 1:100. As secondary antibodies, a polyclonal goat IgG anti-human secretory component (GAHU/SC/PO, NordicBiosite, Täby, Sweden) diluted 1: 2000 in kit buffer was used in the SC ACPA assay (this secondary antibody does not differentiate between secretory IgA or secretory $\operatorname{IgM}$, as it binds to the secretory component), and for the IgA ACPA assay, a polyclonal anti-human antibody diluted 1:2000 was used (Polyclonal Rabbit Anti-Human IgA/HRP, DakoCytomation, Glostrup, Denmark). High-leveled serum samples of IgA and SC ACPA were used to create standard curves. Absorbance was read at $450 \mathrm{~nm}$ (Multiscan RC MOD 351, Labsystems). Cutoff levels for positive serum tests of IgA ACPA were set to 25 arbitrary units (AU)/ $\mathrm{mL}$ [5] and corresponding to the 99th percentile of the 101 healthy blood donors cutoff for SC ACPA was set to $72 \mathrm{AU} / \mathrm{mL}$.

For IgA1 and IgA2 ACPA analyses, serum was diluted 1:50 and the subclasses were detected using anti-IgA1 and anti-IgA2 polyclonal mouse IgG anti-human Fc- region-specific antibodies, conjugated with HRP (IgA1/ IgA2 Antibody, No.ABIN135642/ABIN135642, Antibodies online, Aachen, Germany). Secondary antibodies were diluted 1:500 in the IgA1 assay and 1:400 in the IgA2 assay. Seven-step serial dilutions of high-leveled serum samples were used as a calibrator, and the results were expressed as $\mathrm{AU} / \mathrm{mL}$. Incubation and washing were carried out as instructed by the manufacturer. Absorbance was read at $450 \mathrm{~nm}$ (Multiscan RC MOD 351, Labsystems). Cutoff limits for IgA1 ACPA were set to $27 \mathrm{AU} / \mathrm{mL}$ and for IgA2 ACPA $179 \mathrm{AU} / \mathrm{mL}$.

Total IgA in serum was analyzed with a PEGenhanced immunoturbidimetric method, using Siemens Atellica CH930 (Atellica CH Analyzer, Siemens Healthcare Diagnostics Inc. Tarrytown, NY, USA).

\section{Disease characteristics and risk factors}

At inclusion, the participants answered a questionnaire regarding smoking habits [24]. At the time of sampling, the functional ability of patients was assessed using the Swedish version of the health assessment questionnaire (HAQ) [25], and disease activity was assessed using the 28-joint disease activity score (DAS28) [26]. RF status refers to the time point of RA diagnosis and was retrospectively obtained from medical records.

The prevalence of radiographic erosions was assessed from written reports by experienced radiologists in routine clinical care between 1982 and 2013. Results were dichotomized into having erosions or not.

\section{Genetic analyses}

Genotyping of HLA-DRB1 was performed by Sanger sequencing (BGI Clinical Laboratories, Shenzhen, China). Shared epitope (SE) was defined as HLA-DRB1*01, "0401, "0404, "0405, "0408, "0409, "0410, "0413, "0416, *0419, *0421, or *10.

\section{Statistics}

Statistical analyses were performed using SPSS v. 26.0 (SPSS, Chicago, USA), and two-tailed $p$ values $<0.05$ were considered significant. Antibody test results below the reference curve were given a value corresponding to half of the lowest detected value among patients and controls. Regarding saliva samples, negative delta values (i.e., when OD values for anti-CAP were greater than OD values for anti-CCP) were set to zero.

As IgG ACPA has been known to associate with poorer prognosis [27], comparisons of disease activity, radiographic outcome, smoking habits, and SE status, between IgA/IgA1/IgA2/SC ACPA-positive and ACPAnegative patients were performed only within the subgroup of IgG ACPA-positive patients, in order to avoid the confounding effect of IgG ACPA. Fisher's exact test was used to test differences in proportions regarding 
smoking status, positive tests regarding different salivary, and circulating ACPAs (IgA, IgA1, IgA2, SC, and IgG) and SE. The Mann-Whitney $U$ test was used to relate antibody status in the serum and saliva versus clinical variables, inflammatory markers, HAQ, and levels of other ACPAs. Spearman's rho correlation coefficient $(r)$ was used to test correlations between antibody levels in the saliva and serum. Linear regression analysis was used to evaluate associations between disease activity and levels of salivary IgA ACPA adjusting for levels of serum IgA ACPA, disease duration, and treatment. By including 196 RA patients of which $12 \%$ tested positive for IgA ACPA in the saliva, we achieved $80 \%$ power at alpha $=0.05$ to detect a difference in DAS28 of 0.9 units between patients positive vs. negative for IgA ACPA in saliva.

\section{Results}

Occurrence of IgA ACPA and IgA ACPA subclasses in the saliva and serum

The 196 RA patients included in the SARA study had a mean disease duration of 12.2 years and $80 \%$ were women. Additional baseline characteristics of patients and controls are shown in Table 1. Levels of IgA, IgA1, and IgA2 of ACPA in the saliva and serum in patients with RA and controls are illustrated in Fig. 1.

\section{Saliva}

In the saliva samples, 24 (12\%) patients were positive for IgA ACPA, 19 (10\%) for IgA1, and 18 (9\%) for IgA2. Six saliva samples were positive for all tested IgA ACPA in the saliva (IgA+/IgA1+/IgA2+), 8 were positive for both IgA ACPA subclasses (IgA1+/IgA2+), 11 were positive

Table 1 SARA baseline characteristics

\begin{tabular}{|c|c|c|c|}
\hline & RA patients $(n=196)$ & Blood donors $(n=101)$ & $p$ value \\
\hline \multicolumn{4}{|l|}{ Characteristics } \\
\hline Women, $n(\%)$ & $156 / 196(80)$ & $54 / 101(53)$ & $<0.001$ \\
\hline Age, mean (range) & $63.9(25-87)$ & $48.6(20-74)$ & $<0.001$ \\
\hline Disease duration years, mean (range) & $12.2(0-57)$ & - & \\
\hline Erosions, $n(\%)$ & $109 / 193(56)$ & - & \\
\hline Biologics, $n(\%)$ & $72 / 196(37)$ & - & \\
\hline Glucocorticoids, $n(\%)$ & $52 / 196(27)$ & - & \\
\hline Methotrexate, $n(\%)$ & $148 / 196(76)$ & - & \\
\hline Other csDMARD, $n(\%)$ & $40 / 196(20)$ & - & \\
\hline \multicolumn{4}{|l|}{ Risk factors } \\
\hline Ever smoker, $n(\%)$ & $99 / 192(52)$ & $34 / 99(34)$ & 0.006 \\
\hline Current smoker, $n(\%)$ & $15 / 192(8)$ & $10 / 99(10)$ & 0.514 \\
\hline Never smoker, $n(\%)$ & $93 / 192(48)$ & $65 / 99(66)$ & 0.006 \\
\hline Cigarette pack-years, mean (SD) & $13.9(13.8)$ & $8.3(11.3)$ & 0.009 \\
\hline Shared epitope carriage, $n(\%)$ & $163 / 196(83)$ & $47 / 101(47)$ & $<0.001$ \\
\hline No allele, $n(\%)$ & $34 / 196(17)$ & $54 / 101(54)$ & $<0.001$ \\
\hline One allele, $n(\%)$ & $97 / 196(50)$ & 33/101 (33) & 0.007 \\
\hline Two alleles, $n(\%)$ & $65 / 196(33)$ & $14 / 101(14)$ & $<0.001$ \\
\hline \multicolumn{4}{|l|}{ Antibodies } \\
\hline RF-positive, $n(\%)$ & $145 / 195(74)$ & - & \\
\hline \multicolumn{4}{|l|}{$\lg G A C P A$} \\
\hline Positive, $n(\%)$ & $157 / 196(80)$ & $0 / 101(0)$ & $<0.001$ \\
\hline Level, median U/mL (SD) & $444.1(923.8)$ & $0.1(0.0)$ & $<0.001$ \\
\hline \multicolumn{4}{|l|}{$\operatorname{IgA} A C P A$} \\
\hline Positive, $n(\%)$ & $88 / 196(45)$ & $0 / 101(0)$ & $<0.001$ \\
\hline Level, median AU/mL (SD) & $1.3(151.9)$ & $1.3(0.0)$ & $<0.001$ \\
\hline Level total $\lg A$ in serum, median $\mathrm{g} / \mathrm{L}(\mathrm{SD})$ & $2.5(1.4)$ & $2.0(0.7)$ & $<0.001$ \\
\hline Level total IgA in saliva, median $\mu \mathrm{g} / \mathrm{mL}$ (SD) & $61.5(85.8)$ & $35.7(24.7)$ & $<0.001$ \\
\hline
\end{tabular}




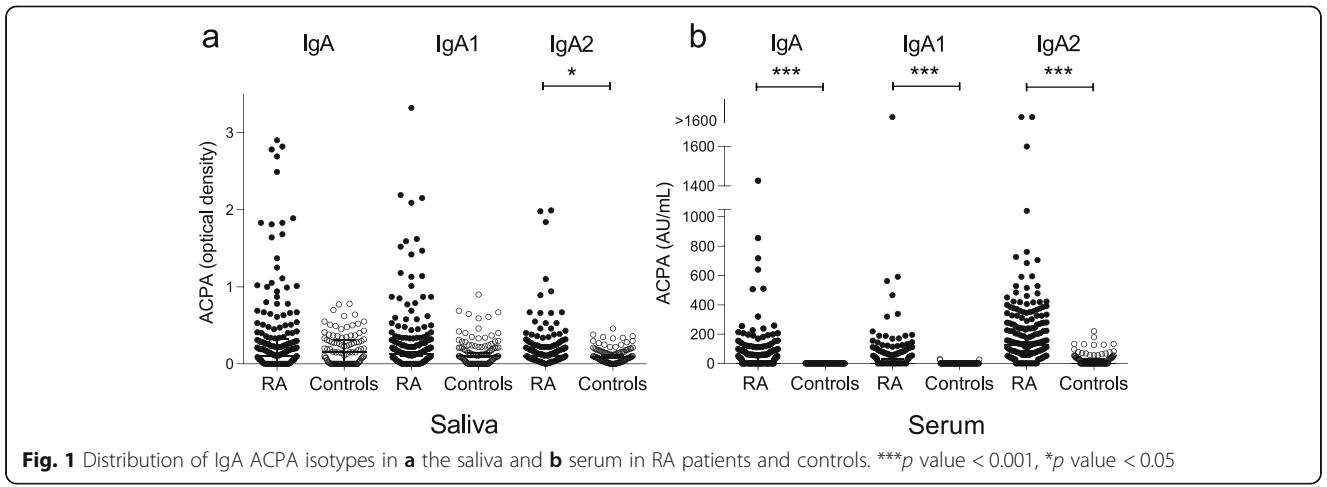

for only $\operatorname{IgA} 1$ (IgA1+/IgA2-), and 10 were positive for only IgA2 (IgA1-/IgA2+) (Fig. 2a). In the saliva samples, 166 were negative for both subclasses (IgA1-/IgA2-).

\section{Serum}

IgG ACPA was detected in 157 (80\%), IgA ACPA in 88 (45\%), and SC ACPA in 42 (21\%) RA patient sera. Serum IgA1 ACPA was detected in 86 (44\%) of the patients and in $76(39 \%)$ for IgA2 (no differences in the prevalence of IgA subclasses, $p=0.356$ ). IgA subclasses as well as SC ACPA occurred predominantly in the IgG ACPApositive subset of the patients. IgG ACPA co-occurred in 87 out of 88 (99\%) IgA ACPA-positive patients, 85 out of 86 (99\%) IgA1 ACPA-positive patients, 73 out of 76 (96\%) IgA2 ACPA-positive patients, and all SC ACPA-positive patients (100\%). Twenty-eight patients were positive for all tested ACPAs in serum (IgG, IgA, IgA1, IgA2, and SC). Sixty were positive for both
IgA ACPA subclasses (IgA1+/IgA2+), 26 positive for only IgA1 (IgA1+/IgA2-), 16 positive for only IgA2 (IgA1-/IgA2+) (Fig. 2b), and 94 negative for both subclasses (IgA1-/IgA2-).

\section{Correlations of different ACPAs in the saliva and serum} Levels of IgA ACPA in the saliva were moderately correlated with serum levels of IgA $(r=0.455)$, IgA1 $(r=$ $0.434)$, and weakly to the other serum ACPA isotypes; IgA2 $(r=0.277)$, SC ACPA $(r=0.29)$, and IgG $(r=$ 0.342 ), all at the $p<0.001$ level (Table 2).

\section{Disease activity in relation to ACPA in the saliva and} serum

Comparisons of disease activity measures were restricted to the serum IgG ACPA-positive patient subset $(n=157)$ as described in the "Methods" section.

\section{a}

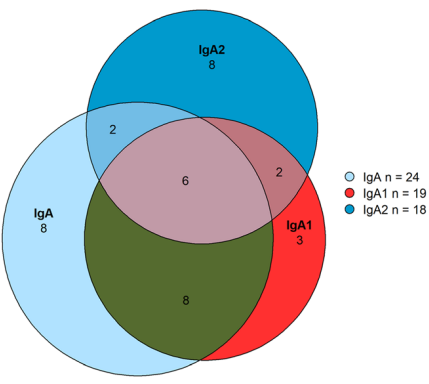

Saliva b

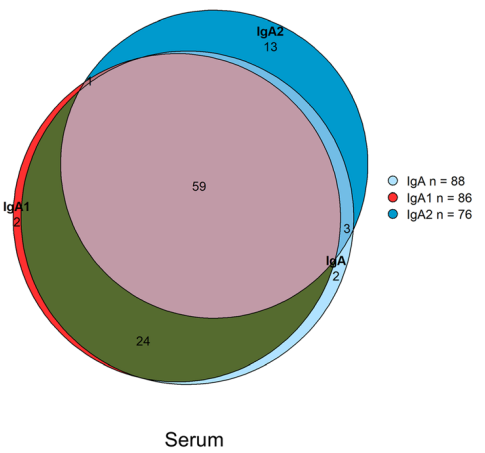

Fig. 2 Venn diagram showing ACPA status of RA patients in $\mathbf{a}$ the saliva and $\mathbf{b}$ serum 
Table 2 Correlations between different ACPAs in the saliva and serum

\begin{tabular}{|c|c|c|c|c|c|c|}
\hline & \multicolumn{2}{|c|}{ Salivary IgA ACPA } & \multicolumn{2}{|c|}{ Salivary IgA1 ACPA } & \multicolumn{2}{|c|}{ Salivary $\lg A 2$ ACPA } \\
\hline & $r$ & $p$ value & $r$ & $p$ value & $r$ & $p$ value \\
\hline \multicolumn{7}{|l|}{ Serum: } \\
\hline $\lg G$ ACPA & 0.342 & $<0.001$ & 0.226 & 0.001 & 0.079 & 0.272 \\
\hline $\operatorname{Ig} A A C P A$ & 0.455 & $<0.001$ & 0.388 & $<0.001$ & 0.119 & 0.097 \\
\hline $\lg A 1 \mathrm{ACPA}$ & 0.434 & $<0.001$ & 0.368 & $<0.001$ & 0.124 & 0.084 \\
\hline $\operatorname{IgA} 2 \mathrm{ACPA}$ & 0.277 & $<0.001$ & 0.158 & 0.027 & 0.110 & 0.126 \\
\hline SC ACPA & 0.290 & $<0.001$ & 0.194 & 0.007 & 0.026 & 0.722 \\
\hline
\end{tabular}

Abbreviations: ACPA anti-cyclic citrullinated peptides, SC secretory component containing, $r$ Spearman's rho correlation coefficient

\section{Saliva}

At the time of sampling, patients positive for IgA ACPA in the saliva had significantly higher erythrocyte sedimentation rate (ESR) (mean 25 vs. $19 \mathrm{~mm} /$ first hour, $p=0.031$ ), DAS28 (mean 3.5 vs. 2.7, $p=0.04$ ), and tender joint count (TJC) (mean 2.0 vs. 1.0, $p=0.039$ ) compared to patients negative for IgA ACPA in the saliva. Also, patients positive for IgA ACPA in the saliva had higher HAQ (mean 1.0 vs. $0.7, p=0.006$ ) and patient global assessment (PGA) (mean 44 vs. 31, $p=0.03$ ) (Fig. 3a-f). Similar significant differences were obtained regarding IgA1 ACPA, but not for IgA2 ACPA (Fig. 3a-f).

In linear regression analysis, salivary ACPA levels are associated with DAS28 $(p=0.016)$, and when adjusting for levels of serum IgA ACPA, the association was borderline significant $(p=0.071)$. DAS28 was associated with levels of salivary IgA ACPA also when adjusting for disease duration and treatment with biologic drugs and/or glucocorticoids at the time of saliva sampling $(p=0.021)$. When analyzing the impact of the secretory rate of the saliva $(\mathrm{mL} / \mathrm{min})$, there was no correlation between levels of salivary IgA ACPA and secretory rate $(r=-0.099, p=0.217)$.

\section{Serum}

Serum IgA, IgA1, and IgA2 ACPA were all associated with significantly higher HAQ and PGA at the time of sampling compared to patients negative for the respective antibody. Patients positive for IgA ACPA in the serum had higher HAQ (mean 0.8 vs. $0.6, p=0.005$ ) and PGA (37 vs. 28, $p=0.014$ ) than patients negative for IgA ACPA. Similar findings were obtained regarding IgA1 and IgA2 ACPA (Fig. 3a-f).

Patients positive for SC ACPA in the serum showed significantly higher levels of ESR (mean 28.3 vs. 16.2, $p=0.002$ ), C-reactive protein (CRP) (mean 14.1 vs. 5.3, $p<0.001$ ), DAS28 (mean 3.4 vs. 2.7, $p=0.011$ ), and HAQ (mean 0.9 vs. $0.6, p=0.029$ ) (Fig. 3a-f).

\section{Radiographic outcome \\ Saliva and serum}

Among patients who developed the erosive disease, the first radiographic erosion was detected at a mean time of
2.9 years (SD 6.0 years) after diagnosis. The presence of radiographic erosions did not differ significantly between groups according to saliva or serum IgA, IgA1, or IgA2 ACPA status (Supplementary Table 1). Neither did SC ACPA status in serum associate with radiographic erosions.

\section{Smoking habits and genetic disposition (shared epitope)}

Smoking habits and carriage of SE in patients and controls are shown in Table 1. "Ever smoking" was significantly more common among RA patients compared to controls ( $52 \%$ vs. $34 \%, p=0.006)$ while "current smoking" was not. SE was detected in 163 of 196 (83\%) of the RA patients and in 47 of 101 (47\%) of controls $(p<0.001)$.

\section{Saliva}

None of the salivary ACPAs was associated with smoking status (data not shown) or pack-years (Fig. 4b).

\section{Serum}

Smoking status did not differ significantly according to the status of serum IgA ACPA (including subclasses) or SC ACPA (Fig. 4a). However, the number of pack-years among ever smokers were higher regarding serum IgA, IgA1, and SC ACPA, but not for IgA2 ACPA (Fig. 4b). As expected, serum IgG ACPA-positive patients had higher proportions of SE-positivity compared to IgGnegative patients $(89 \%$ vs. $62 \%, p<0.001)$. When only IgG ACPA-positive patients were included in the analyses, no difference in SE carriage was detected according to serum status of IgA, IgA1, IgA2, or SC ACPA (Fig. 4c).

\section{Discussion}

To our knowledge, this is the largest study to date addressing salivary ACPAs in RA. We characterized the IgA ACPA and IgA ACPA subclass response in paired saliva and serum samples and investigated possible clinical implications. Our main findings are that IgA ACPA responses in the oral cavity as well as in the circulation associate with a more clinically active disease. 


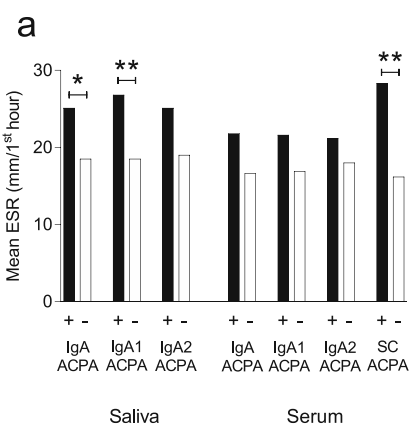

C

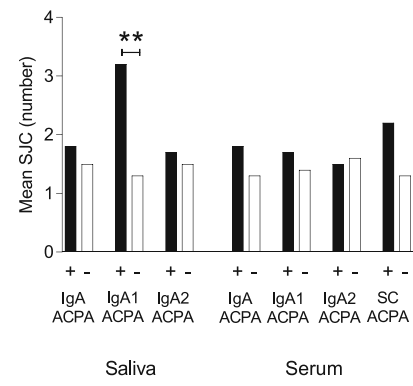

e

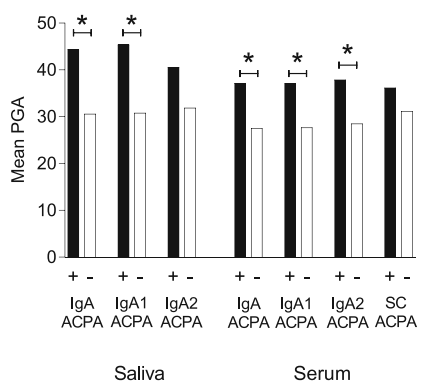

b

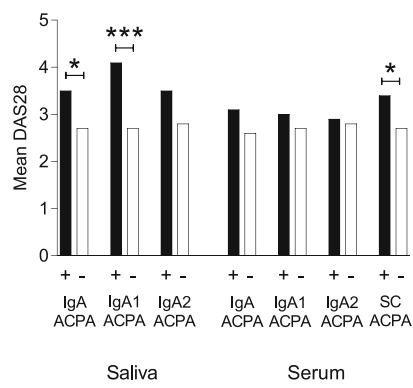

d

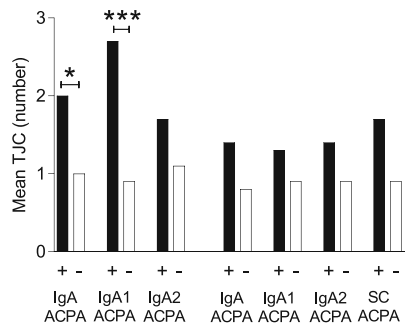

Saliva

Serum

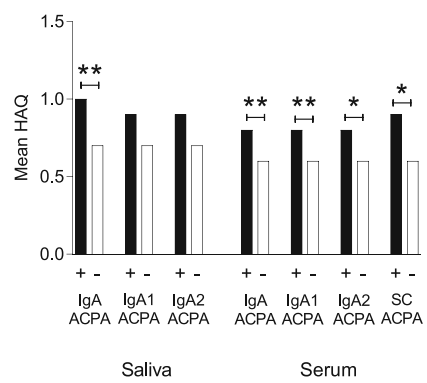

Fig. 3 Antibody status versus disease characteristics at the time of sampling, regarding a erythrocyte sedimentation rate (ESR), $\mathbf{b}$ disease activity score 28 (DAS28), c swollen joint count (SJC), $\mathbf{d}$ tender joint count (TJC), e patient global assessment (PGA), and $\mathbf{f}$ health assessment questionnaire (HAQ). ${ }^{* *} p$ value $<0.001,{ }^{* *} p$ value $<0.01,{ }^{*} p$ value $<0.05$

In our previous pilot study, IgA ACPA in the saliva occurred in $22 \%$ of RA patients and was associated with signs of a milder disease [6]. The present study is the first to confirm the occurrence of salivary ACPA in a subgroup of RA patients, yet the occurrence of IgA ACPA was now lower (12\%) in the current, much larger, study population. We could not corroborate the previously suggested negative association between radiographic joint erosions and IgA ACPA in the saliva [6]. Instead, this larger study shows that patients positive for salivary IgA ACPA have higher disease activity at the time of sampling also when considering disease duration and treatment. Furthermore, IgA ACPA levels in the saliva appeared more robustly associated with disease activity than serum levels. Taken together, this suggests that oral mucosal immune responses to citrullinated proteins 


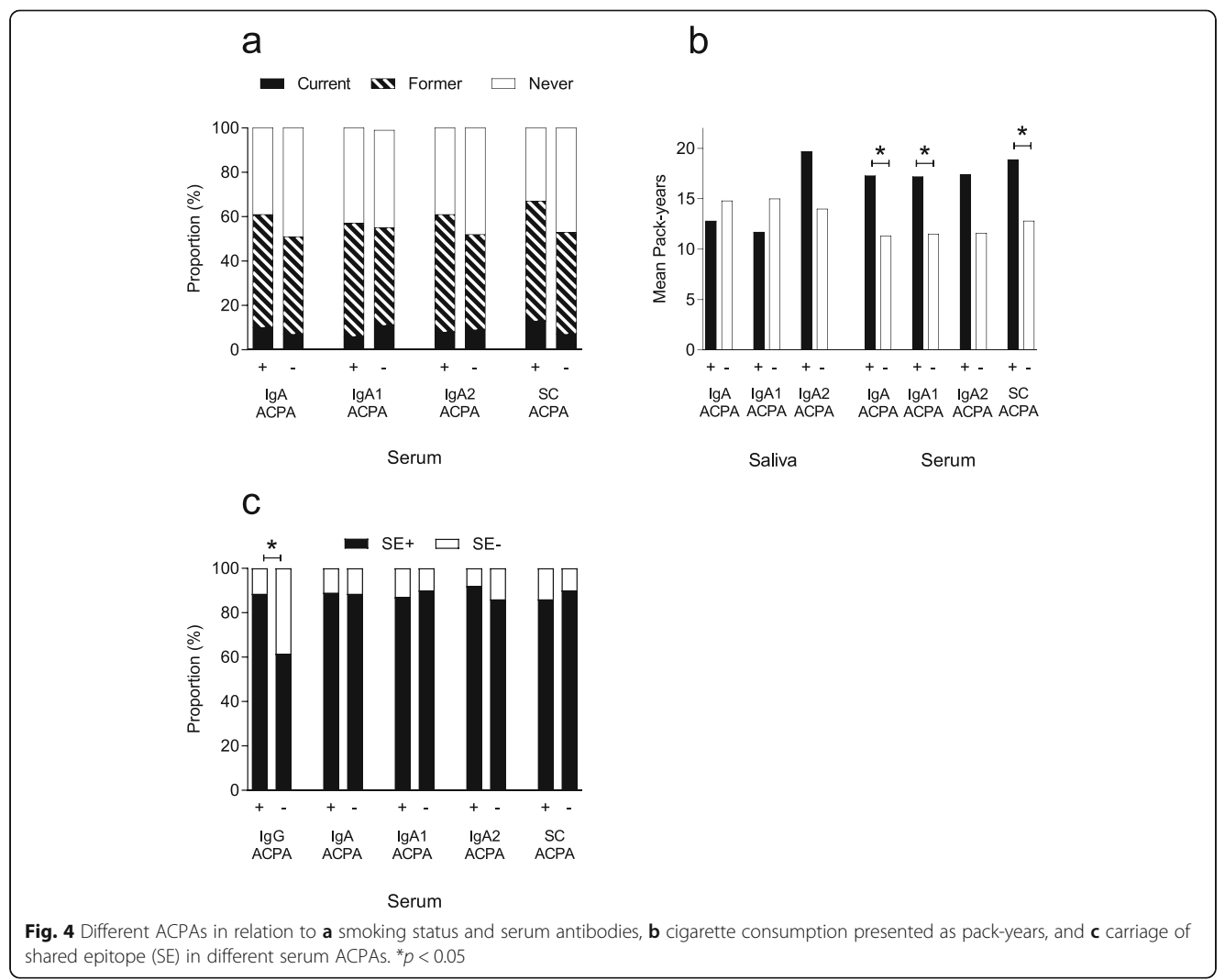

may trigger effector mechanisms in the RA pathogenesis. In the saliva, ACPA of IgA1 and IgA2 subclasses were uncommon, which hampered further analyses concerning clinical characteristics and RA risk factors.

In serum, IgA1 ACPA was detected in $44 \%$ and IgA2 ACPA in $39 \%$ of the patients. A previous study on circulating RF IgA subclasses by Otten et al. found circulating IgA1 RF (73\%) to be twice as common as IgA2 RF (36\%) in RA [23]. Speculatively, our results may suggest that mucosal immunization to citrullinated proteins are particularly relevant in compartments with pronounced IgA2 dominance, such as the lower gastrointestinal tract [12, 28]. Although total IgA2 in serum has recently been found to be more pro-inflammatory than IgA1 in vitro [29], we could not see any difference between serum IgA1 ACPA and IgA2 ACPA regarding their association to disease activity. In the saliva, the reverse was noticed with higher disease activity among IgA1 ACPA-positive patients.

Circulating SC ACPA has in previous studies been found to associate with increased ESR and CRP levels in early RA $[17,18]$. Also, in this population of established RA patients, serum SC ACPA is associated with increased disease activity as well as functional disability. However, the correlations between SC ACPA in the serum and IgA ACPA in the saliva were weak and lower than previously reported concerning the lungs and serum SC ACPA [17]. We expected a stronger correlation between circulating SC ACPA and salivary IgA ACPA, as SC ACPA in the circulation supposedly reflects the occurrence of ACPA at mucosal linings. Circulating antibodies containing the $\mathrm{SC}$ can be of IgA or IgM isotype, and regarding SC ACPA, IgM has been shown to be the most abundant isotype [30]. Also, free SC correlates more to IgM than does IgA ACPA [31], which could also be an explanation for the weak correlation seen in this study.

Cigarette smoking, causing local irritation of respiratory mucosa, is a possible inducer of ACPA production in RA [24] and associates primarily with mucosaassociated ACPAs $[18,20]$. Citrullinated proteins are 
present in the oral cavity, as shown by immunohistochemical studies on gingival tissue biopsies. The expression of citrullinated proteins appears increased in inflamed tissue [32-34], but the association with smoking was either absent [34] or not investigated [32, 33]. In the present study, there was no association between smoking and IgA ACPA in the saliva, and we could not confirm our hypothesis that IgA2 ACPA would have a stronger association than IgA1 ACPA to smoking. Concerning serum antibodies, there were associations with pack-years, but not with smoking status. The low proportion of current smokers may have contributed to this.

The strengths of this study are the large number of included patients and the paired saliva and serum samples. A limitation is that the radiographic outcome was based on written reports from radiologists, but not subjected to formal scoring. This approach obviously reduces the level of detail, but we still regard that clinically relevant erosive disease could be identified in this way. Also, the cross-sectional design introduces the risk that treatment attenuated possible clinical differences and possibly influenced antibody levels. Finally, the lower mean age among controls may have influenced IgA cutoff levels, as it may associate with age in non-RA patients [35].

For future directions, longitudinal studies are preferred to investigate the possible predictive value of IgA ACPAs in the saliva and serum.

\section{Conclusion}

This large cross-sectional study confirms the presence of salivary IgA ACPA in a small subset of RA patients, in association with a higher disease activity and functional impairment. This suggests that mucosal ACPA responses in the oral cavity may contribute to diseasepromoting processes in RA.

\section{Supplementary Information}

Supplementary information accompanies this paper at https://doi.org/10. 1186/s13075-020-02363-0.

Additional file 1 : Supplementary Table 1. Radiographic joint erosions versus ACPA isotypes. Abbreviations: ACPA anti-cyclic citrullinated peptides, SC secretory component containing.

\section{Abbreviations \\ ACPA: Anti-citrullinated protein antibodies; CAP: Citrullinated arginine peptide; CCP: Cyclic citrullinated peptide; CRP: C-reactive protein; \\ DAS28: Disease activity score 28; ELISA: Enzyme-linked immunosorbent assay; ESR: Erythrocyte sedimentation rate; HAQ: Health Assessment Questionnaire; OD: Optical density; PGA: Patient global assessment; RA: Rheumatoid arthritis; RF: Rheumatoid factor; SC: Secretory component; SE: Shared epitope (HLA- DRB1); SIgA: Secretory IgA; SJC: Swollen joint count; TJC: Tender joint count}

\section{Acknowledgements}

We wish to thank the EIRA study group for sharing the questionnaire regarding smoking habits.

\section{Authors' contributions}

AS and AK designed the study, and AS recruited the study subjects. KRL and EB performed the laboratory work. KRL, KM, JW, AK, and AS analyzed the data. All authors contributed with the writing and critical revising of the manuscript, and all authors approved the final version.

\section{Funding}

This study was supported by grants from the Center for Clinical Research Dalarna, Swedish Society of Medicine, The Swedish Research Council, Medical Research Council of Southeast Sweden, Reinhold Sund foundation, King Gustaf V's 80-year foundation, the Swedish Rheumatism Association, and the Östergötland County Council.

\section{Availability of data and materials}

The datasets used and/or analyzed during the current study are available from the corresponding author on reasonable request.

\section{Ethics approval and consent to participate}

This study was approved by the ethical review board in Uppsala, Sweden, and all participants signed a written informed consent.

\section{Consent for publication}

Not applicable.

\section{Competing interests}

The authors declare that they have no competing interest.

\section{Author details}

${ }^{1}$ Division of Inflammation and Infection, Department of Biomedical and Clinical Sciences, Linköping University, Linköping, Sweden. ${ }^{2}$ Center for Clinical Research Dalarna, Uppsala University, Uppsala, Sweden. ${ }^{3}$ Department of Rheumatology in Östergötland, Linköping, Sweden.

Received: 25 May 2020 Accepted: 25 October 2020 Published online: 23 November 2020

References

1. Demoruelle MK, Deane KD, Holers VM. When and where does inflammation begin in rheumatoid arthritis? Curr Opin Rheumatol. 2014;26(1) (1531-6963 (Electronic)):64-71.

2. Holers VM, Demoruelle MK, Kuhn KA, Buckner JH, Robinson WH, Okamoto Y, et al. Rheumatoid arthritis and the mucosal origins hypothesis: protection turns to destruction. Nat Rev Rheumatol. 2018;14(9):542-57.

3. Rantapaa-Dahlqvist S, de Jong BA, Berglin E, Hallmans G, Wadell G, Stenlund $\mathrm{H}$, et al. Antibodies against cyclic citrullinated peptide and IgA rheumatoid factor predict the development of rheumatoid arthritis. Arthritis Rheum. 2003:48(10):2741-9.

4. Kokkonen H, Mullazehi M, Berglin E, Hallmans G, Wadell G, Ronnelid J, et al. Antibodies of $\lg G, \lg A$ and $\lg M$ isotypes against cyclic citrullinated peptide precede the development of rheumatoid arthritis. Arthritis Res Ther. 2011; 13(1):R13

5. Svard A, Kastbom A, Reckner-Olsson A, Skogh T. Presence and utility of IgAclass antibodies to cyclic citrullinated peptides in early rheumatoid arthritis: the Swedish TIRA project. Arthritis Res Ther. 2008;10(4):R75.

6. Svard A, Kastbom A, Sommarin Y, Skogh T. Salivary lgA antibodies to cyclic citrullinated peptides (CCP) in rheumatoid arthritis. Immunobiology. 2013; 218(2):232-7.

7. Bakema JE, van Egmond M. The human immunoglobulin A Fc receptor FcalphaRl: a multifaceted regulator of mucosal immunity. Mucosal Immunol. 2011;4(6):612-24

8. Brandtzaeg P. Secretory IgA: designed for anti-microbial defense. Front Immunol. 2013:4:222.

9. Breedveld A, van Egmond M. IgA and FcalphaRl: pathological roles and therapeutic opportunities. Front Immunol. 2019;10:553.

10. Woof JM, Russell MW. Structure and function relationships in IgA. Mucosal Immunol. 2011;4(6):590-7.

11. Pakkanen SH, Kantele JM, Moldoveanu Z, Hedges S, Hakkinen M, Mestecky J, et al. Expression of homing receptors on $\lg \mathrm{A} 1$ and $\lg \mathrm{A} 2$ plasmablasts in blood reflects differential distribution of $\lg A 1$ and $\lg A 2$ in various body fluids. Clin Vaccine Immunol. 2010;17(3):393-401. 
12. Delacroix D, Dive C, Rambaud JC, Vaerman JP. IgA subclasses in various secretions and in serum. Immunology. 1982:47(0019-2805 (Print)):383-5.

13. Kazeeva TN, Shevelev AB. Unknown functions of immunoglobulins $A$. Biochemistry (Mosc). 2007;72(0006-2979 (Print)):485-94

14. Waldman RH, Mach JP, Stella MM, Rowe DS. Secretory lgA in human serum. J Immunol. 1970;105(1):43-7.

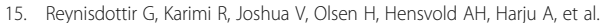
Structural changes and antibody enrichment in the lungs are early feature of anti-citrullinated protein antibody-positive rheumatoid arthritis. Artritis Rheumatol. 2014;66(1):31-9.

16. Willis VC, Demoruelle MK, Derber LA, Chartier-Logan CJ, Parish MC, Pedraza IF, et al. Sputum autoantibodies in patients with established rheumatoid arthritis and subjects at risk of future clinically apparent disease. Arthritis Rheum. 2013;65(10):2545-54.

17. Roos Ljungberg K, Joshua V, Skogh T, Eklund A, Sköld CM, Karimi R, et al. Secretory anti-citrullinated protein antibodies in serum associate with lung involvement in early rheumatoid arthritis. Rheumatology (Oxford). 2020; 59(4):852-9.

18. Roos K, Martinsson K, Ziegelasch M, Sommarin Y, Svard A, Skogh T, et al. Circulating secretory IgA antibodies against cyclic citrullinated peptides in early rheumatoid arthritis associate with inflammatory activity and smoking. Arthritis Res Ther. 2016;18(1):119.

19. Lakos G, Soos L, Fekete A, Szabo Z, Zeher M, Horvath IF, et al. Anti-cyclic citrullinated peptide antibody isotypes in rheumatoid arthritis: association with disease duration, rheumatoid factor production and the presence of shared epitope. Clin Exp Rheumatol. 2008;2(0392-856X (Print)):253-60.

20. Svard A, Skogh T, Alfredsson L, llar A, Klareskog L, Bengtsson C, et al. Associations with smoking and shared epitope differ between $\operatorname{lgA}$ - and $\lg G$ class antibodies to cyclic citrullinated peptides in early rheumatoid arthritis. Artritis Rheumatol. 2015;67(2326-5205 (Electronic)):2032-7.

21. Hitchon CA, Chandad F, Ferucci ED, Willemze A, loan-Facsinay A, van der Woude $D$, et al. Antibodies to porphyromonas gingivalis are associated with anticitrullinated protein antibodies in patients with rheumatoid arthritis and their relatives. J Rheumatol. 2010;37(6):1105-12.

22. Courbon G, Rinaudo-Gaujous M, Blasco-Baque V, Auger I, Caire R, Mijola L, et al. Porphyromonas gingivalis experimentally induces periodontis and an anti-CCP2-associated arthritis in the rat. Ann Rheum Dis. 2019;78(5):594-9.

23. Otten HG, Daha MR, van Laar JM, de Rooy HH, Breedveld FC. Subclass distribution and size of human IgA rheumatoid factor at mucosal and nonmucosal sites. Arthritis Rheum. 1991;34(7):831-9.

24. Klareskog L, Stolt P, Lundberg K, Kallberg H, Bengtsson C, Grunewald J, et al. A new model for an etiology of rheumatoid arthritis: smoking may trigger HLA-DR (shared epitope)-restricted immune reactions to autoantigens modified by citrullination. Arthritis Rheum. 2006;54(1):38-46.

25. Ekdahl C, Eberhardt K, Andersson SI, Svensson B. Assessing disability in patients with rheumatoid arthritis. Use of a Swedish version of the Stanford Health Assessment Questionnaire. Scand J Rheumatol. 1988;17(4):263-71.

26. Prevoo ML, Van 't Hof MA, Kuper HH, van Leeuwen MA, van de Putte $L B$, van Riel PL. Modified disease activity scores that include twenty-eight-joint counts. Development and validation in a prospective longitudinal study of patients with rheumatoid arthritis. Arthritis Rheum 1995:38(1):44-48.

27. Kastbom A, Strandberg G, Lindroos A, Skogh T. Anti-CCP antibody test predicts the disease course during 3 years in early rheumatoid arthritis (the Swedish TIRA project). Ann Rheum Dis. 2004;63(9):1085-9.

28. Kett K, Brandtzaeg P, Radl J, Haaijman JJ. Different subclass distribution of IgA-producing cells in human lymphoid organs and various secretory tissues. J Immunol. 1986;136(0022-1767 (Print)):3631-5.

29. Steffen U, Koeleman CA, Sokolova MV, Bang H, Kleyer A, Rech J, et al. IgA subclasses have different effector functions associated with distinct glycosylation profiles. Nat Commun. 2020;11(1):120

30. van Delft MAM, van der Woude D, Toes REM, Trouw LA. Secretory form of rheumatoid arthritis-associated autoantibodies in serum are mainly of the lgM isotype, suggesting a continuous reactivation of autoantibody responses at mucosal surfaces. Ann Rheum Dis. 2019;78(1):146-8.

31. Martinsson K, Roos Ljungberg K, Ziegelasch M, Cedergren J, Eriksson P, Klimovich $V$, et al. Elevated free secretory component in early rheumatoid arthritis and prior to arthritis development in patients at increased risk. Rheumatology (Oxford). 2020;59(5):979-87.

32. Engstrom $M$, Eriksson $K$, Lee $L$, Hermansson $M$, Johansson A, Nicholas $A P$, et al. Increased citrullination and expression of peptidylarginine deiminases independently of $\mathrm{P}$. gingivalis and $\mathrm{A}$. actinomycetemcomitans in gingival tissue of patients with periodontitis. J Transl Med. 2018;16(1):214

33. Harvey GP, Fitzsimmons TR, Dhamarpatni AASSK, Marchant C, Haynes DR, Bartold PM. Expression of peptidylarginine deiminase- 2 and -4 , citrullinated proteins and anti-citrullinated protein antibodies in human gingiva. J Periodontal Res. 2013;48(2):252-61.

34. Nesse W, Westra J, van der Wal JE, Abbas F, Nicholas AP, Vissink A, et al. The periodontium of periodontitis patients contains citrullinated proteins which may play a role in ACPA (anti-citrullinated protein antibody) formation. J Clin Periodontol. 2012;39(7):599-607.

35. Berens HM, Polinski KJ, Mikuls TR, Khatter S, August J, Visser A, et al. Anticyclic citrullinated peptide antibodies 3.1 and anti-CCP-IgA are associated with increasing age in individuals without rheumatoid arthritis. Rheumatol. 2019;46(12):1556-9.

\section{Publisher's Note}

Springer Nature remains neutral with regard to jurisdictional claims in published maps and institutional affiliations.

Ready to submit your research? Choose BMC and benefit from:

- fast, convenient online submission

- thorough peer review by experienced researchers in your field

- rapid publication on acceptance

- support for research data, including large and complex data types

- gold Open Access which fosters wider collaboration and increased citations

- maximum visibility for your research: over 100M website views per year

At BMC, research is always in progress.

Learn more biomedcentral.com/submissions 



\section{Circulating anti-citrullinated protein antibodies containing secretory component are prognostic for arthritis onset in at-risk patients}

\author{
K. Roos Ljungberg, ${ }^{* \dagger}$ \\ K. Martinsson (D) , J. Wetterö (D) ,* \\ A. Svärd (iD *t and A. Kastbom ${ }^{* \neq}$ \\ ${ }^{*}$ Division of Inflammation and \\ Infection, Department of Biomedical and \\ Clinical Sciences, Linköping University, \\ Linköping, Sweden, ${ }^{\dagger}$ Center for Clinical \\ Research Dalarna, Uppsala University, \\ Uppsala, and ${ }^{\ddagger}$ Department of Rheumatology in \\ Östergötland, Linköping University Hospital, \\ Linköping, Sweden
}

\author{
Accepted for publication 23 February 2021 \\ Correspondence: K. Martinsson, Division of \\ Inflammation and Infection, Department of \\ Biomedical and Clinical Sciences, \\ II/Rheumatology, Entrance No. 68, floor 12, \\ Linköping University, Campus US, \\ SE-581 85 Linköping, Sweden. \\ E-mail: klara.martinsson@liu.se
}

\begin{abstract}
Summary
Autoantibodies related to rheumatoid arthritis (RA), such as anticitrullinated protein antibodies (ACPA), are often detectable in the preclinical period years before arthritis onset. However, events triggering arthritis development remain incompletely known. We aimed to determine whether ACPA isotype levels are prognostic for arthritis development in patients presenting with immunoglobulin (Ig)G ACPA and musculoskeletal pain. Study participants $(n=82)$ had musculoskeletal pain of any sort and duration and a positive IgG ACPA test. None of the patients had arthritis upon clinical examination at baseline, but during follow-up (mean $=6$ years), $48 \%$ developed at least one arthritic joint. IgG, IgA, IgM and secretory component (SC)-containing ACPA was measured in longitudinally collected serum samples. Cox regression analysis was performed to test the prognostic value of baseline antibody levels and changes over time. All analysed ACPA isotype levels were associated with arthritis development in univariable Cox regression analysis. In multivariable analysis, baseline SC ACPA levels were independently prognostic for arthritis development in multivariable analysis [hazard ratio $(\mathrm{HR})=\mathbf{1 . 0 0 6}, 95 \%$ confidence interval $(\mathrm{CI})=\mathbf{1 . 0 0 1 - 1 \cdot 0 1 0}, P=0.012]$. There were no significant changes in ACPA isotype levels over time, and no significant association between changes over time and arthritis development. In this prospective longitudinal study, baseline serum SC ACPA levels, but neither IgG, IgA nor IgM ACPA are prognostic for future arthritis development. Repeated measurement of ACPA isotypes do not bring additional prognostic value. The results reinforce a mucosal connection in RA development and encourage further exploration of the mechanisms underlying secretory ACPA formation as a trigger for arthritis development.
\end{abstract}

Keywords: anti-citrullinated protein antibodies, at-risk patients, mucosa, rheumatoid arthritis, secretory component

\section{Introduction}

Rheumatoid arthritis (RA) is believed to develop gradually, including a preclinical period where circulating autoantibodies, such as anti-citrullinated protein antibodies (ACPA) and rheumatoid factor (RF), occur [1,2] while synovial inflammation is absent [3].

In retrospective studies, approximately $40 \%$ of RA patients tested positive for circulating immunoglobulin (Ig)G ACPA before symptom onset, with increasing levels and percentage positive closer to diagnosis [4,5]. This translates into an absolute risk of RA between 5 and 16\% among asymptomatic individuals with IgG ACPA positivity, but the risk increases if joint symptoms co-occur. Prospective observational studies reported progression to arthritis in $20-50 \%$ within a few years of IgG ACPA-positive individuals with musculoskeletal symptoms [6-11].

The mechanisms by which ACPA production is induced remain enigmatic, and there is still poor understanding of the early events triggering arthritis years after 
appearance of ACPA in the circulation. Emerging evidence suggests an important mucosal contribution in both ACPA formation and arthritis development in ACPA-positive individuals [12]. Secretory IgA (SIgA) is the dominating antibody at mucosal linings, where it is formed upon attachment of a secretory component (SC) to dimeric IgA [13]. We previously reported secretory component (SC)containing ACPAs in the circulation in recent-onset RA patients in association with increased inflammatory markers and radiographic lung abnormalities [14,15].

There is an apparent clinical need to improve the prediction of arthritis development among ACPA-positive patients with arthralgia. Results from previous retrospective studies of asymptomatic individuals imply that ACPA dynamics in the circulation are relevant to monitor to improve the prognostic accuracy in this group of patients $[4,5,16]$. However, a recent prospective study on symptomatic patients could not establish an added value of assessing changes in serum IgG ACPA serum levels over time [17]. Baseline autoantibody analyses have suggested a 'dose-response' relationship between autoantibody load and risk of arthritis development in symptomatic at-risk patients $[10,18]$ but, to our knowledge, repeated isotypespecific ACPA analyses have not been addressed previously. SC ACPA and IgA ACPA are of particular relevance in this context, given the increasing interest in mucosal processes as triggers of ACPA-positive RA [19]. Hence, we aimed to investigate whether levels of different ACPA isotypes, or changes therein, are prognostic for arthritis development in IgG ACPA-positive patients with musculoskeletal symptoms.

\section{Materials and methods}

\section{Study population}

We studied 82 IgG ACPA-positive patients without baseline clinical arthritis included in a prospective observational cohort study denoted TIRx (Swedish for 'extra-early rheumatology follow-up') at the University Hospital in Linköping, Sweden [10]. Patients referred from primary care centers between 2010 and 2013 were enrolled upon fulfilment of the inclusion criteria musculoskeletal pain and positive IgG anti-cyclic citrullinated peptide (antiCCP2) serum test in clinical routine. Patients with previous inflammatory rheumatic disease or corticosteroid treatment (oral or intra-articular) within 6 weeks prior to screening were excluded. The ethical review board in Linköping, Sweden, approved the study protocol (decision numbers M220-09 and 2017/260-32) and all participants signed a written informed consent.

Regular follow-up visits, including serum sampling, were carried out during follow-up [10], and in cases of aggravated symptoms patients were offered extra clinical examination and serum sampling. Arthritis development was defined by the findings upon clinical examination by an experienced rheumatologist. Follow-up time was a median of 6 years [interquartile range $(\mathrm{IQR})=40 \cdot 8-6 \cdot 8$ ].

As controls for ACPA analyses, we recruited 100 blood donors (mean age $=52$ years, $50 \%$ female).

\section{Antibody}

Measurements of IgG and IgA ACPA were performed by a fluoroenzyme immunoassay with cyclic citrullinated peptide (CCP) 2 as antigen on a PhaDia 250 instrument (EliA; ThermoFisher AB, Uppsala, Sweden). In the IgA ACPA assay, a mouse anti-human IgA antibody detecting both subclasses was used as secondary antibody (ThermoFisher AB). The serum IgG-class anti-CCP (antiCCP) enzyme-linked immunoassay (ELISA) tests (CCPlus Immunoscan; Svar Life Science, Malmö, Sweden) were modified to analyse IgM ACPA [20] and SC ACPA [14], respectively. SC ACPA were analysed by diluting serum samples $1: 25$ in kit buffer and the secondary antibody detecting human secretory component was diluted $1: 2000$ (polyclonal goat antibody conjugated to horseradish peroxidase, GAHu/SC/PO; Nordic Biosite, Täby, Sweden). Incubation and washing were performed according to the manufacturer's instructions. A standard curve was calculated by diluting a known serum sample with high level of SC ACPA in a series from $1: 12.5$ to $1: 800$ and then used to recalculate optical densities into arbitrary units. Interassay coefficient of variation (CV) was $9 \%$ and intra-assay $\mathrm{CV}$ was $2 \%$ in the SC ACPA assay. The intraand interassay variations in the IgM ACPA ELISA were 2 and $17 \%$, respectively. In the IgM and SC ACPA assays, all samples were analysed in duplicate and reanalysed whenever the coefficient of variation between duplicates was > $20 \%$.

ACPA isotype levels were above the upper limit of detection in 35 samples (27 for IgG ACPA, five for IgA ACPA and three for IgM ACPA), and thus further diluted $1 / 10$ (IgG and $\operatorname{Ig} A$ ) or 1/50 (IgM) and reanalysed. Cut-off levels were set by an accredited clinical immunology laboratory in Linköping to $\geq 7 \mathrm{U} / \mathrm{ml}$ for IgG. The cut-off for IgA ACPA was set to $>12 \mathrm{U} / \mathrm{ml}$ (corresponding to the 99th percentile among controls). Cut-off levels for IgM ACPA and SC ACPA were set according to the 99th percentile among 100 controls (322 and $124 \mathrm{AU} / \mathrm{ml}$, respectively).

For investigation into ACPA isotype level changes, we used serum samples taken at inclusion and at the visit where arthritis development was confirmed. In patients who did not develop arthritis during follow-up, we analysed serum from inclusion and the 12-month sample. Sera were available from 31 patients from inclusion and the visit where progression to arthritis was confirmed. Baseline and 12-month sera were available from 40 patients who did not progress to arthritis during follow-up. 
RF was analysed using nephelometry at the accredited Clinical Chemistry Laboratory at Linköping University Hospital.

\section{Statistical analysis}

Statistical analysis was performed by SPSS version 26 (SPSS, Inc., Chicago, IL, USA) and GraphPad Prism version 8 for Windows (GraphPad Software, San Diego, CA, USA). Two-sided $P$-values $<0.05$ were considered statistically significant and differences between two groups were tested by Fisher's exact test. The Mann-Whitney $U$-test was used to analyse symptom duration, compare the ACPA status of different isotypes and risk factors and compare net changes (follow-up levels subtracted from baseline levels), and relative (follow-up levels divided by baseline levels) ACPA level change in the group progressing to clinical arthritis versus non-progressors. Wilcoxon's signed-rank test was used to test differences in ACPA levels between baseline and follow-up (i.e. when arthritis was confirmed, or after 12 months for patients not progressing). Pearson's $\chi^{2}$ test was used to test the distribution of the number of ACPA isotypes when comparing more than two groups. Spearman's signed-rank test was used to test correlation between antibody levels. Cox regression was used to test different ACPA levels, isotype usage, risk factors and clinical variables versus progression to arthritis. Statistically significant variables in univariable Cox regression analyses were included in a multivariable Cox regression analysis.

\section{Ethics approval}

The ethical review board in Linköping, Sweden, approved the study protocol and all participants signed a written informed consent (decision numbers M220-09 and 2017/260-32).

\section{Results}

Baseline characteristics of the TIRx cohort are detailed in Table 1. During follow-up, 39 patients (48\%) developed clinical arthritis after a median of 6 months (IQR $=3-24$ months).

Table 1. Baseline characteristics of the TIRx cohort

\begin{tabular}{|c|c|c|c|c|}
\hline & All patients $(n=82)$ & Developing arthritis $(n=39)$ & No arthritis during follow-up $(n=43)$ & $P$-value ${ }^{\mathrm{c}}$ \\
\hline \multicolumn{5}{|l|}{ Demographics } \\
\hline Women, $n(\%)$ & $66(81)$ & $32(82)$ & $34(79)$ & $0 \cdot 786$ \\
\hline Age, mean (range) & $51 \cdot 8(18-76)$ & $55 \cdot 0(25-76)$ & $48 \cdot 9(18-75)$ & $0 \cdot 089$ \\
\hline Time to arthritis, median (IQR) & & $6(3-24)$ & & \\
\hline Follow-up time, median (IQR) & & & $69(57-77)$ & \\
\hline \multicolumn{5}{|l|}{ Symptom duration } \\
\hline $0-6$ months $n(\%)$ & $15(18)$ & $8(21)$ & $7(16)$ & $0 \cdot 514$ \\
\hline $6-18$ months $n(\%)$ & $37(45)$ & $15(38)$ & $22(51)$ & \\
\hline $18+$ months $n(\%)$ & $30(37)$ & $16(41)$ & $14(33)$ & \\
\hline \multicolumn{5}{|l|}{ Risk factors } \\
\hline Ever smoker, $n(\%)$ & $39(48)$ & $19(49)$ & $20(47)$ & 1 \\
\hline Never smoker, $n(\%)$ & $43(52)$ & $20(51)$ & $23(53)$ & \\
\hline Shared epitope carrier, $n(\%)$ & $52(64)^{\mathrm{a}}$ & $24(62)$ & $28(67)^{b}$ & $0 \cdot 82$ \\
\hline \multicolumn{5}{|l|}{ Antibodies } \\
\hline RF positive, $n(\%)$ & $24(30)$ & $16(41)$ & $8(19)$ & $0 \cdot 031$ \\
\hline IgA ACPA-positive, $n(\%)$ & $19(23)$ & $10(26)$ & $9(21)$ & $0 \cdot 794$ \\
\hline IgM ACPA-positive, $n(\%)$ & $12(15)$ & $9(23)$ & $3(7)$ & 0.06 \\
\hline SC ACPA-positive, $n(\%)$ & $17(21)$ & $12(31)$ & $5(12)$ & $0 \cdot 055$ \\
\hline IgG ACPA level (U/ml, mean \pm s.d.) & $229 \pm 489$ & $340 \pm 586$ & $128 \pm 359$ & $0 \cdot 213$ \\
\hline IgA ACPA level (U/ml, mean \pm s.d.) & $10 \pm 17$ & $24 \pm 65$ & $7 \pm 9$ & $0 \cdot 584$ \\
\hline IgM ACPA level AU/ml, mean \pm s.d.) & $6 \pm 16$ & $10 \pm 23$ & $3 \pm 2$ & 0.003 \\
\hline SC ACPA level (AU/ml, mean \pm s.d.) & $89 \pm 118$ & $130 \pm 156$ & $52 \pm 45$ & $0 \cdot 082$ \\
\hline \multicolumn{5}{|l|}{ Isotype usage } \\
\hline One, $n(\%)$ & $56(68)$ & $26(67)$ & $30(70)$ & $0 \cdot 014$ \\
\hline Two, $n(\%)$ & $12(15)$ & $2(5)$ & $10(23)$ & \\
\hline Three, $n(\%)$ & $6(7)$ & $4(10)$ & $2(5)$ & \\
\hline Four, $n(\%)$ & $8(10)$ & $7(18)$ & $1(2)$ & \\
\hline
\end{tabular}

Demographics analysed using Fisher's exact test, symptom duration using Pearson's $\chi^{2}$ test, risk factors using Pearson's $\chi^{2}$ or Fisher's exact tests, antibodies using Fisher's exact test or Mann-Whitney $U$-test and isotype usage using Pearson's $\chi^{2}$ test.

$\mathrm{IQR}=$ interquartile range, $\mathrm{RF}=$ rheumatoid factor, $\mathrm{ACPA}=$ anti-citrullinated protein antibodies, $\mathrm{SC}=$ secretory component-containing; $\mathrm{s} . \mathrm{d}$. = standard deviation; Ig = immunoglobulin; TIRx = Swedish acronym for 'extra-early rheumatology follow-up'.

${ }^{a}$ Data from 81 patients; ${ }^{b}$ data from 42 patients; ${ }^{c}$ compared between the groups developing arthritis and no arthritis during follow-up. 


\section{Occurrence of ACPA isotypes and changes in levels}

Baseline status and levels of ACPA isotypes are shown in Table 1. Baseline levels of IgM ACPA were significantly $(P=0.003)$ higher among patients subsequently developing arthritis than among those who did not, while SC ACPA showed borderline $(P=0 \cdot 082)$ statistical significance (Table 1). Baseline levels of SC ACPA correlated moderately with IgA ACPA levels (Supporting information, Fig. S1).
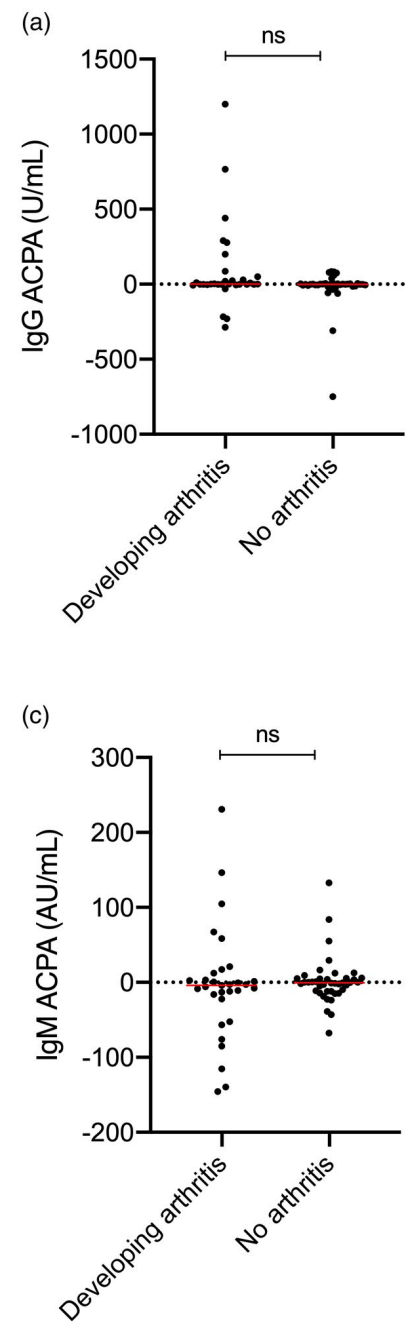

Regarding proportion positive tests, only SC ACPA showed borderline significance $(P=0.055$, Table 1$)$.

Change in ACPA status was uncommon during followup (at 12 months or at time of arthritis): four of the IgG-positive patients (two of whom changed from positive to negative), two for IgA, five for IgM (two became negative) and four concerning SC ACPA (one became negative). Conversion to/from positive or negative was not associated with progression to arthritis (data not shown).
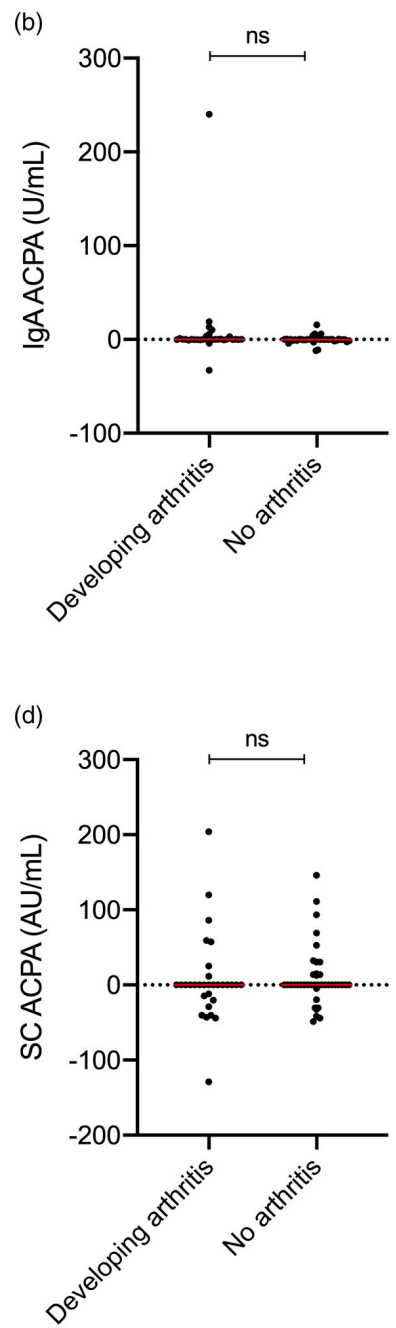

Fig. 1. Net change (follow-up levels subtracted from baseline levels) in levels of anti-citrullinated protein antibodies (ACPAs) of immunoglobulin (Ig) G, IgA, IgM and secretory component-containing (SC) isotype in patients developing $(n=31)$ and not developing arthritis $(n=40)$ during follow-up; n.s. = not significant; dotted line represents no change and horizontal red lines = median. 
At the visit when clinical arthritis was confirmed, ACPA isotype levels were not significantly altered compared to baseline (Supporting information, Fig. S2). This was also the case among patients who did not develop arthritis during follow-up, where baseline levels were compared to the 12-month visit (Supporting information, Fig. S3). Furthermore, there were no significant differences in relative changes of ACPA isotypes during follow-up (Supporting information, Table S1).

\section{ACPA isotypes in association to smoking habits and shared epitope}

Smoking habits and carriage of the human leukocyte antigen (HLA)-DRB1 shared epitope (SE) are detailed in

(a)

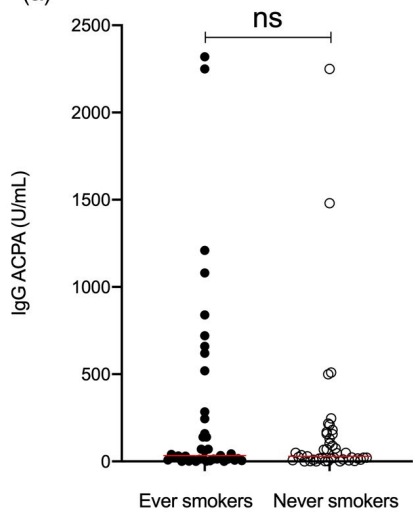

(c)

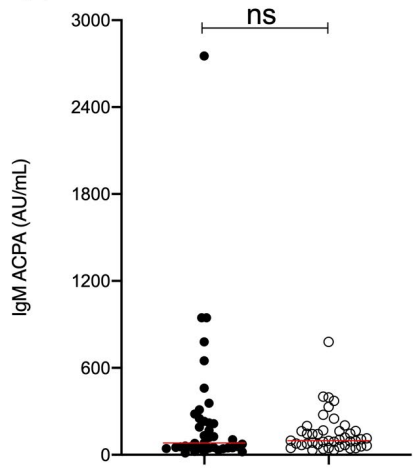

Ever smokers Never smokers
Table 1. Levels of baseline SC ACPA were significantly higher among ever smokers compared to never smokers (median $=66$ versus $25 \mathrm{AU} / \mathrm{ml}, P=0.035$ ), while none of the other ACPA isotypes differed significantly according to smoking status (Fig. 2). The carriage of SE was not associated with altered baseline levels of any ACPA tested (Supporting information, Table S2).

\section{Antibody levels as prognostic factors for arthritis development}

In univariable Cox regression analyses, baseline levels of all tested autoantibodies were associated with progression to arthritis (Table 2). As previously reported [10], baseline disease activity score 28 (DAS28), C-reactive protein (CRP)

(b)

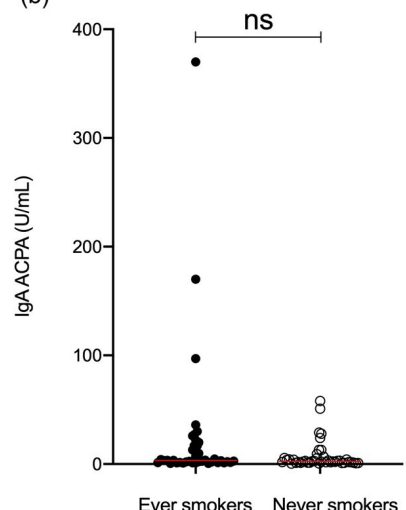

(d)

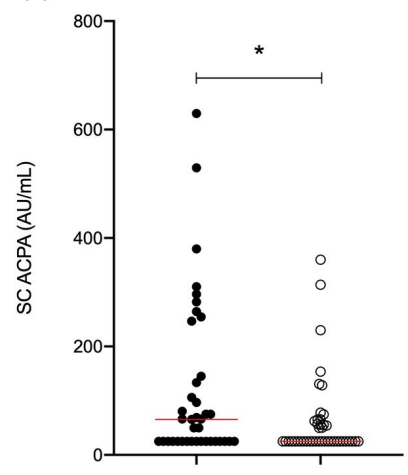

Ever smokers Never smokers

Fig. 2. Smoking habits in relation to different anti-citrullinated protein antibody (ACPA) isotypes [immunoglobulin (Ig)G, IgA, IgM and secretory component-containing (SC)] in early rheumatology follow-up [Swedish acronym for 'extra-early rheumatology follow-up' (TIRx)] patients. ${ }^{\star} P$-value $<0 \cdot 05$, horizontal red lines $=$ median . 
Table 2. Cox regression analyses regarding baseline factors versus arthritis development in patients at increased risk $(n=82)$

\begin{tabular}{|c|c|c|c|c|}
\hline & \multicolumn{2}{|c|}{ Univariable analysis } & \multicolumn{2}{|c|}{ Multivariable analysis } \\
\hline & $\mathrm{HR}(95 \% \mathrm{CI})$ & $P$-value & $\operatorname{HR}(95 \% \mathrm{CI})$ & $P$-value \\
\hline Age & $1.021(0.998-1.046)$ & $0 \cdot 077$ & & \\
\hline Women & $1.109(0.489-2.514)$ & $0 \cdot 804$ & & \\
\hline Ever smoking & $1.008(0.537-1.891)$ & 0.980 & & \\
\hline Shared epitope-positive & $0.880(1.462-1.678)$ & 0.699 & & \\
\hline RF level & $1.005(1.003-1.007)$ & $<0.001$ & $1.000(0.995-1.005)$ & 0.966 \\
\hline IgG ACPA level (U/ml) & $1.001(1.000-1.001)$ & 0.009 & $0.999(0.998-1.001)$ & $0 \cdot 371$ \\
\hline IgA ACPA level (U/ml) & $1.006(1.001-1.011)$ & 0.011 & $0.986(0.967-1.005)$ & $0 \cdot 153$ \\
\hline IgM ACPA level (AU/ml) & $1.000(1.000-1.000)$ & $0 \cdot 001$ & $1.000(1.000-1.000)$ & $0 \cdot 168$ \\
\hline SC ACPA level (AU/ml) & $1.005(1.003-1.007)$ & $<0.001$ & $1.006(1.002-1.011)$ & 0.008 \\
\hline DAS28 & $1.366(1.018-1.834)^{a}$ & $0 \cdot 038$ & $1.225(0.861-1.744)$ & $0 \cdot 259$ \\
\hline CRP (mg/l) & $1.056(1.020-1.093)$ & 0.002 & $1.028(0.937-1.128)$ & 0.553 \\
\hline ESR (mm/1st hour) & $1.035(1.005-1.068)^{b}$ & 0.032 & & \\
\hline
\end{tabular}

$P$-value $<0.05$ are marked bold in the table.

$\mathrm{HR}=$ hazard ratio, $\mathrm{RF}=$ rheumatoid factor, $\mathrm{ACP}=$ anti-citrullinated protein antibodies, $\mathrm{SC}=$ secretory component containing, $\mathrm{DAS} 28=$ disease activity score, $\mathrm{CRP}=\mathrm{C}$-reactive protein, $\mathrm{ESR}=$ erythrocyte sedimentation rate; $\mathrm{CI}=$ confidence interval; $\mathrm{Ig}=$ immunoglobulin. Values are from baseline $\left({ }^{\mathrm{a}} n=77\right.$ and ${ }^{\mathrm{b}} n=81$ ). ESR are not included in multivariable analysis as being a part of disease activity score 28 (DAS28).

and erythrocyte sedimentation rate (ESR) were also significantly prognostic for arthritis in univariable analyses, while smoking and SE were not (Table 2).

In a multivariable Cox regression analysis including variables with a $P$-value $<0.05$ in univariable analysis, baseline SC ACPA levels remained independently associated with progression to arthritis [hazard ratio $(\mathrm{HR})=1 \cdot 006,95 \%$ confidence interval $(\mathrm{CI})=1 \cdot 002-1 \cdot 011$, $P=0.008]$. Changes in ACPA isotype levels were not significantly different between patients who developed arthritis compared to those who did not (Fig. 1), and were not prognostic for arthritis development in Cox regression analyses $(P>0.3$ for all).

In a separate Cox regression analysis evaluating isotype usage, the HR for progressing to arthritis was 1.44 per additional ACPA isotype present (95\% CI $=1.07-1.94$, $P=0 \cdot 017)$.

\section{Discussion}

This is the first prospective study, to our knowledge, to address isotype-specific ACPA responses over time in patients at increased risk of RA. We find that baseline levels of circulating SC ACPA are prognostic for arthritis development when also considering the autoantibodies in current clinical use; that is, IgG ACPA and RF. This suggests that mucosal immunization to citrullinated proteins is important for progression into clinical arthritis among patients with an already established systemic autoantibody response. In a recent study on symptom-free first-degree-relatives to RA patients, we showed that SC ACPA was rare while other ACPA isotypes occurred frequently [21]. Seen together with the current findings, it could be speculated that SC ACPA formation is more related to the triggering of arthritis than to the development of a systemic ACPA response. Surprisingly, we found no significant increase in SC ACPA levels as arthritis approached. Although the patient cohort was followed long-term, most patients developing arthritis did so within a short time-frame from baseline (median $=6$ months), and therefore the most pronounced SC ACPA increase may already have occurred prior to inclusion in the study.

The origin of circulating SC ACPA remains to be unraveled. Mucosal surfaces of the lungs could be the induction site, as we found a clear association between smoking and SC ACPA in this at-risk population, which aligns with previous reports on early RA $[14,15]$. Furthermore, SC ACPA is found in bronchoalveolar lavage fluid and serum levels associate with radiographic lung abnormalities [15]. However, other mucosal compartments may also be involved, and the relative importance of each compartment could differ between patients. For instance, it was recently shown that intestinal permeability increases before arthritis onset in both mice and humans, and reversal of this process prevented arthritis development [22]. Such increased leakage of the gut could hypothetically increase the exposure of citrullinated proteins to the local immune system and promote SC ACPA formation [23]. The oral cavity may also be of importance, as circulating SC ACPA correlates with salivary IgA ACPA and is associated with RA disease activity [24]. Thus, a limitation of the current study is that specific mucosal compartments were not addressed. Also, the selection of IgG ACPA-positive patients, which was based on clinical practice in Sweden, may have influenced the prognostic performance of other ACPA isotypes. However, we previously showed that IgM, IgA and SC ACPA rarely occur among IgG ACPA-negative subjects $[14,21,25]$, which reduces the risk of such bias. 
Previous studies have highlighted that the IgG ACPA repertoire expands prior to arthritis onset $[4,5,16,26]$ although, in symptomatic individuals, that an increasing number of ACPA reactivities predicts arthritis development remains to be shown. In the present study, we similarly found that ACPA isotype usage at baseline is prognostic for progression into arthritis, but as relatively few patients seroconverted we are unable to establish that increasing isotype usage predicts arthritis development. To this end, a larger patient cohort would be required.

Several studies, including previous data from the current cohort, have highlighted the prognostic importance of IgG ACPA levels in at-risk patients $[7,10,18]$. Therefore, it is intriguing that the prognostic value of baseline IgG ACPA levels were no longer evident when SC ACPA was added to the multivariable model. Also, the lack of serum level increase for any of the investigated isotypes during arthritis development is surprising from a mechanistic viewpoint, but is still in agreement with a previous study concerning IgG ACPA [17].

In summary, this prospective longitudinal study on ACPA isotypes shows that baseline SC ACPA serum levels are prognostic for arthritis development, but that repeated measurements do not bring additional prognostic value in IgG ACPA-positive symptomatic at-risk patients. The results reinforce a mucosal connection in RA development and encourage further exploration of the mechanisms underlying secretory ACPA formation in relation to arthritis onset.

\section{Acknowledgements}

This study was supported by grants from the Center for Clinical Research Dalarna, the Swedish Society of Medicine, the Swedish Research Council, Medical Research Council of Southeast Sweden, the Reinhold Sund foundation, King Gustaf V's 80-year foundation, the Swedish Rheumatism association and the Östergötland County Council. The authors would like to thank the Clinical Immunology Laboratory, Linköping University Hospital for analyzing IgG and IgA ACPA. We would also like to thank all patients and blood donors participating in the TIRx study.

\section{Disclosures}

The authors declare no conflicts of interest.

\section{Author contributions}

K. R. L. drafted the manuscript and all authors contributed with the writing and critical revising of the manuscript. K. M. performed the IgM and SC ACPA analyses. A. K. conceived the study and was responsible for patient recruitment and characterization. All authors contributed to statistical analysis of the data. All authors approved the final version of the manuscript.

\section{Data Availability Statement}

The data set used and/or analysed during the current study are available from the corresponding author on reasonable request.

\section{References}

1 Gerlag DM, Raza K, van Baarsen LG et al. EULAR recommendations for terminology and research in individuals at risk of rheumatoid arthritis: report from the Study Group for Risk Factors for Rheumatoid Arthritis. Ann Rheum Dis 2012; 71:638-41

2 Molendijk M, Hazes JM, Lubberts E. From patients with arthralgia, pre-RA and recently diagnosed RA: what is the current status of understanding RA pathogenesis? RMD Open 2018; 4:e000256.

3 de Hair MJ, van de Sande MG, Ramwadhdoebe TH et al. Features of the synovium of individuals at risk of developing rheumatoid arthritis: implications for understanding preclinical rheumatoid arthritis. Arthritis Rheumatol 2014; 66:513-22.

4 Nielen MM, van Schaardenburg D, Reesink HW et al. Specific autoantibodies precede the symptoms of rheumatoid arthritis: a study of serial measurements in blood donors. Arthritis Rheum 2004; 50:380-6.

5 Rantapää-Dahlqvist S, de Jong BA, Berglin E et al. Antibodies against cyclic citrullinated peptide and IgA rheumatoid factor predict the development of rheumatoid arthritis. Arthritis Rheum 2003; 48:2741-9.

6 Bos WH, Wolbink GJ, Boers M et al. Arthritis development in patients with arthralgia is strongly associated with anticitrullinated protein antibody status: a prospective cohort study. Ann Rheum Dis 2010; 69:490-4.

7 van de Stadt LA, Witte BI, Bos WH, van Schaardenburg D. A prediction rule for the development of arthritis in seropositive arthralgia patients. Ann Rheum Dis 2013; 72:1920-6.

8 Rakieh C, Nam JL, Hunt L et al. Predicting the development of clinical arthritis in anti-CCP positive individuals with non-specific musculoskeletal symptoms: a prospective observational cohort study. Ann Rheum Dis 2015; 74:1659-66.

9 Nam JL, Hunt L, Hensor EM, Emery P. Enriching case selection for imminent RA: the use of anti-CCP antibodies in individuals with new non-specific musculoskeletal symptoms - a cohort study. Ann Rheum Dis 2016; 75:1452-6.

10 Eloff E, Martinsson K, Ziegelasch M et al. Autoantibodies are major predictors of arthritis development in patients with anticitrullinated protein antibodies and musculoskeletal pain. Scand J Rheumatol 2020;1-9.

11 Gerlag DM, Safy M, Maijer KI et al. Effects of B-cell directed therapy on the preclinical stage of rheumatoid arthritis: the PRAIRI study. Ann Rheum Dis 2019; 78:179-85. 
12 Holers VM, Demoruelle MK, Kuhn KA et al. Rheumatoid arthritis and the mucosal origins hypothesis: protection turns to destruction. Nat Rev Rheumatol 2018; 14:542-57.

13 Brandtzaeg P. Secretory IgA: designed for anti-microbial defense. Front Immunol 2013; 4:222.

14 Roos K, Martinsson K, Ziegelasch M et al. Circulating secretory IgA antibodies against cyclic citrullinated peptides in early rheumatoid arthritis associate with inflammatory activity and smoking. Arthritis Res Ther 2016; 18:119.

15 Roos Ljungberg K, Joshua V, Skogh T et al. Secretory anti-citrullinated protein antibodies in serum associate with lung involvement in early rheumatoid arthritis. Rheumatology 2020; 59:852-9.

16 Sokolove J, Bromberg R, Deane KD et al. Autoantibody epitope spreading in the pre-clinical phase predicts progression to rheumatoid arthritis. PLOS ONE 2012; 7:e35296.

17 van Beers-Tas $\mathrm{MH}$, Stuiver MM, de Koning M, van de Stadt LA, Geskus RB, van Schaardenburg D. Can an increase in autoantibody levels predict arthritis in arthralgia patients? Rheumatology 2018; 57:932-4.

18 Ten Brinck RM, van Steenbergen HW, van Delft MAM et al. The risk of individual autoantibodies, autoantibody combinations and levels for arthritis development in clinically suspect arthralgia. Rheumatology 2017; 56:2145-53.

19 Mankia K, Emery P. Is localized autoimmunity the trigger for rheumatoid arthritis? Unravelling new targets for prevention. Discov Med 2015; 20:129-35

20 Kastbom A, Roos Ljungberg K, Ziegelasch M, Wettero J, Skogh T, Martinsson K. Changes in anti-citrullinated protein antibody isotype levels in relation to disease activity and response to treatment in early rheumatoid arthritis. Clin Exp Immunol 2018; 194:391-9.

21 Svard A, Roos Ljungberg K, Brink M et al. Secretory antibodies to citrullinated peptides in plasma and saliva from rheumatoid arthritis patients and their unaffected first-degree relatives. Clin Exp Immunol 2020; 199:143-9.
22 Tajik N, Frech M, Schulz O et al. Targeting zonulin and intestinal epithelial barrier function to prevent onset of arthritis. Nat Commun 2020; 11:1995.

23 Menard S, Cerf-Bensussan N, Heyman M. Multiple facets of intestinal permeability and epithelial handling of dietary antigens. Mucosal Immunol 2010; 3:247-59.

24 Roos Ljungberg K, Borjesson E, Martinsson K, Wettero J, Kastbom A, Svard A. Presence of salivary IgA anti-citrullinated protein antibodies associate with higher disease activity in patients with rheumatoid arthritis. Arthritis Res Ther 2020; 22:274.

25 Svärd A, Skogh T, Alfredsson L et al. Associations with smoking and shared epitope differ between IgA- and IgG-class antibodies to cyclic citrullinated peptides in early rheumatoid arthritis. Arthritis Rheumatol 2015; 67:2032-7.

26 van de Stadt LA, de Koning MH, van de Stadt RJ et al. Development of the anti-citrullinated protein antibody repertoire prior to the onset of rheumatoid arthritis. Arthritis Rheum 2011; 63:3226-33.

\section{Supporting Information}

Additional supporting information may be found in the online version of this article at the publisher's web site:

Fig. S1. Correlation of baseline IgA ACPA and SC ACPA levels in at-risk patients $(\mathrm{n}=82)$.

Fig. S2. Levels of anti-citrullinated protein antibodies (ACPAs) of IgG, IgA, IgM and SC isotype at baseline and arthritis debut $(\mathrm{n}=31) . \mathrm{ns}=$ not significant.

Fig. S3. Levels of anti-citrullinated protein antibodies (ACPAs) of IgG, IgA, IgM and SC isotype at baseline and at month 12 in patients not developing arthritis during follow-up $(\mathrm{n}=40)$. $\mathrm{ns}=$ not significant. 


\section{FACULTY OF MEDICINE AND HEALTH SCIENCES}

Linköping University Medical Dissertation No. 1798, 2022

Department of Biomedical and Clinical Sciences

Linköping University

SE-581 83 Linköping, Sweden

www.liu.se 